CAIO GENTIL RIBEIRO

INTERPRETAÇÃO E OBRIGAÇÃO DE OBEDECER: O PAPEL DA LEGITIMIDADE NO DIREITO

Dissertação de mestrado

Orientador: Professor Titular Dr. Ronaldo Porto Macedo Jr.

UNIVERSIDADE DE SÃO PAULO

FACULDADE DE DIREITO

SÃO PAULO - SP 

CAIO GENTIL RIBEIRO

\title{
INTERPRETAÇÃO E OBRIGAÇÃO DE OBEDECER: O PAPEL DA LEGITIMIDADE NO DIREITO
}

\begin{abstract}
Dissertação apresentada a Banca Examinadora do Programa de Pós-Graduação em Direito, da Faculdade de Direito da Universidade de São Paulo, como exigência parcial para obtenção do título de Mestre em Direito, na área de concentração em Filosofia e Teoria Geral do Direito, sob orientação do Prof. Titular Dr. Ronaldo Porto Macedo Júnior. Versão corrigida.
\end{abstract}

UNIVERSIDADE DE SÃO PAULO

FACULDADE DE DIREITO

SÃO PAULO - SP 
Ribeiro, Caio Gentil

Interpretação e obrigação de obedecer: o papel da legitimidade no direito ; Caio Gentil Ribeiro ; orientador Ronaldo Porto Macedo Jr. -- São Paulo,

115 p. Filosofia do Direito e Teoria Geral do Direito) Faculdade de Direito, Universidade de São Paulo, 2019.

1. Filosofia do Direito. 2. Interpretação. 3. Interpretativismo. 4. Positivismo, 5 . Obrigação política. I. Macedo Jr., Ronaldo Porto, orient. II. Título. 


\title{
INTERPRETAÇÃO E OBRIGAÇÃO DE OBEDECER: O PAPEL DA LEGITIMIDADE NO DIREITO
}

\begin{abstract}
Dissertação apresentada a Banca Examinadora do Programa de Pós-Graduação em Direito, da Faculdade de Direito da Universidade de São Paulo, como exigência parcial para obtenção do título de Mestre em Direito, na área de concentração em Filosofia e Teoria Geral do Direito, sob orientação do Prof. Titular Dr. Ronaldo Porto Macedo Júnior.
\end{abstract}

Data de aprovação:

\section{Banca Examinadora}

Prof.(a) Dr.(a):

Instituição: . Assinatura:

Prof.(a) Dr.(a):

Instituição: . Assinatura:

Prof.(a) Dr.(a):

Instituição: . Assinatura: 



\section{Agradecimentos}

Primeiramente, agradeço ao Professor Ronaldo Porto Macedo Jr. pela orientação nesta dissertação, bem como por tudo que pude aprender nos grupos de estudos, monitorias e cursos sob sua responsabilidade que acompanhei desde os tempos da graduação. Em todas essas oportunidades, aprendi, na prática, o valor de um debate franco e rigoroso de ideias e pude me convencer de que o direito pode ser interessante.

Agradeço aos professores Thomas Bustamante e Rafael Mafei pela leitura atenta da versão preliminar deste trabalho para o exame de qualificação e pelas recomendações que fizeram sobre diversos pontos que deveriam ser melhorados. Espero ter conseguido contemplá-las.

Agradeço a Marcela Mattiuzzo e Guilherme Bandeira por comentários que fizeram a capítulos deste trabalho bem como a versões preliminares.

Agradeço a Daniel Murata e Jacqueline Abreu pela leitura integral que fizeram de versões finais deste trabalho e pelas sugestões que deram para o esclarecimento de diversas questões. Agradeço, também, pela generosidade de dedicarem algumas horas para discutir versões preliminares do trabalho, o que foi essencial para que eu pudesse decidir que direções ele tomaria.

Last but not least, agradeço a Carolina Linhares pela ajuda na revisão do texto para a qualificação e do texto final. 

"Então porque um sem-vergonha desordeiro se arrelia, bota-se um cabra na cadeia, dá-se pancada nele? Sabia perfeitamente que era assim, acostumara-se a todas as violências, a todas, as injustiças. E aos conhecidos que dormiam no tronco e aguentavam cipó de boi oferecia consolações: - 'Tenha paciência. Apanhar do governo não é desfeita.' Mas agora rangia os dentes, soprava. Merecia castigo?

E, por mais que forcejasse, não se convencia de que o soldado amarelo fosse governo. Governo, coisa distante e perfeita, não podia errar. O soldado amarelo estava ali perto, além da grade, era fraco e ruim, jogava na esteira com os matutos e provocava-os depois.

O governo não devia consentir tão grande safadeza.

Afinal para que serviam os soldados amarelos? Deu um pontapé na parede, gritou enfurecido. Para que serviam os soldados amarelos?"

(Graciliano Ramos, Vidas Secas) 



\section{RESUMO}

RIBEIRO, Caio Gentil. Interpretação e obrigação de obedecer: o papel da legitimidade no direito. 115 p. Mestrado - Faculdade de Direito, Universidade de São Paulo, São Paulo, 2019.

Este é um trabalho sobre o papel da questão da legitimidade política na identificação de o que o direito é. Trato desse tema apresentando as teorias do direito de Joseph Raz, que dissocia completamente essas questões, e de Ronald Dworkin, que entende que elas estão diretamente relacionadas. No Capítulo 2, é apresentada a "tese das fontes" de Joseph Raz, segundo a qual a identificação do direito deve ser feita exclusivamente através de fatos, e trato de quais podem ser os propósitos de uma teoria do direito pensada nesses termos. No Capítulo 3, apresento os argumentos de Dworkin em sentido contrário, destacando como, para ele, definir quais proposições jurídicas são corretas depende de definir quais critérios de correção reforçam a legitimidade do estado e, consequentemente, a obrigação dos cidadãos de obedecer ao seu direito. O Capítulo 4 é sobre o argumento conceitual de Dworkin, segundo o qual o direito é uma espécie do que ele chama de conceito interpretativo e o positivismo cria teorias falhas ao tentar explicar o conceito de direito como o que ele chama de conceito criterial. O Capítulo 5 aborda a tese de Dworkin de que o direito é parte da moral e enfrenta a questão de se ainda temos alguma razão para buscar a diferença entre direito e moralidade, respondendo ao argumento de Scott Hershovitz de que deveríamos abandonar essa busca. Por fim, defendo que uma teoria do direito consciente do papel de justificação da coerção deve construir seus critérios de identificação do direito buscando fazer sentido dessa justificação, adotando uma abordagem normativa que vise reforçar a obrigação política dos cidadãos.

\section{Palavras-chave:}

Ronald Dworkin; Joseph Raz; Teoria do Direito; interpretação; obrigação política; legitimidade; positivismo; interpretativismo 


\begin{abstract}
RIBEIRO, Caio Gentil. Interpretação e obrigação de obedecer: o papel da legitimidade no direito. 115 p. Master - Faculty of Law, University of São Paulo, São Paulo, date, São Paulo, 2019.
\end{abstract}

This work is about the role of the issue of political legitimacy on the identification of what law is. I face this topic by presenting the theories of Joseph Raz, which completely dissociates those two issues, and Ronald Dworkin, which takes them to be directly related. On Chapter 2, I present Raz's "source thesis" which prescribes that law's identification must be made solely through facts and I face the question of what could be the purposes of a theory thought in such terms. On Chapter 3, I present Dworkin's arguments against that view, highlighting how, for him, to define which legal propositions are correct depends on defining which legal propositions' truth conditions increase state's legitimacy and, thus, citizens' obligation to obey its law. Chapter 4 is about Dworkin's conceptual argument, according to which law is an example of what he calls an interpretive concept and positivism develops false theories in trying to explain the concept of law as what he calls a criterial concept. Chapter 5 presents Dworkin's thesis that law is a part of morality and addresses the question of whether we still have any reason to search for the difference between law and morality, arguing against Scott Hershovitz's thesis that we should abandon that search. Finally, I argue that a theory of law which is conscious of law's role of justifying coercion must construct law's truth conditions trying to make sense of this role, adopting a normative approach which seeks to strengthen citizens' political obligation.

\title{
Key-words
}

Ronald Dworkin; Joseph Raz; Legal Theory; interpretation; political obligation; legitimacy; positivism; interpretivism 


\section{ÍNDICE}

1. INTRODUCÃ̃O

1.1. O QUE LEGITIMIDADE TEM A VER COM DIREITO?

1.2. TEORIAS SOBRE A OBRIGAÇÃo POLÍTICA E TEORIA DO DIREITO 3

1.3. POR QUE DWORKIN?

1.4. Por que Raz? 6

1.5. OBJETIVOS E ORGANIZAÇ̃̃o DO TRABALHO

2. DESCREVER SEM JUSTIFICAR: A TESE DAS FONTES DE JOSEPH RAZ 12

2.1. O QUE É AUTORIDADE?

2.2. AUTORIDADE E DIREITO

2.3. DiREITO E MORALIDADE: A TESE DAS FONTES

2.4. OBRIGAÇÃo de OBEDECER AO DIREITO 21

2.5. O QUE PODE SER UMA TEORIA DO DIREITO?

2.6. UM ABISMO ENTRE O QUE O DIREITO EXIGE E O QUE PODE SER JUSTIFICADO 25

3. TEORIA DO DIREITO COMO JUSTIFICACÃO: A ABORDAGEM DE \begin{tabular}{lr} 
RONALD DWORKIN & 28 \\
\hline
\end{tabular}

3.1. TEORIAS SOBRE OS FUNDAMENTOS DO DIREITO 30

3.1.1. VALidADE E CONTEÚdO DO DIREITO 32

3.2. Direito COMO JUSTIFICAÇão da COERÇ̃̃o 34

3.2.1. TEORIA DO DIREITO E IGUALDADE 40

3.2.2. LEGITIMIDADE E CONTEÚDO DO DIREITO 43

3.3. DIVERGÊNCIAS TEÓRICAS E POINT DO DIREITO 45

3.3.1. CETICISMO, PRAGMATISMO E TEORIA DO DiREITO 50

3.3.2. O DiREITO INJUSTO É UM PARADOXO? 52

3.4. O DIREITO ALÉM DOS TRIBUNAIS 56

3.5. UMA TEORIA QUE NOS DIGA O QUE FAZER: CONTINUIDADE ENTRE TEORIA E PRÁTICA 61

3.6. POR QUE NÃO UMA TEORIA SOBRE O CONCEITO SOCIOLÓGICO DE DIREITO? $\quad 67$

4. ONDE ERRARAM OS POSITIVISTAS? O ARGUMENTO DA CONFUSÃO

$\begin{array}{ll}\text { CONCEITUAL } & 71\end{array}$ 
4.1. A TIPOlogia de CONCEITOS DE DWORKIN 71

4.2. CONCEITOS INTERPRETATIVOS

4.2.1. CONCEITOS E CONCEPÇÕES 77

4.2.2. ATÉ ONDE PODE IR A INTERPRETAÇÃO DE UM CONCEITO?

4.3. QUE TIPO DE CONCEITO É O CONCEITO DE DIREITO?

4.3.1. DIVERGÊNCIAS E CONCEITOS CRITERIAIS 83

4.3.2. O DIREITO COMO CONCEITO INTERPRETATIVO 84

5. O DIREITO COMO PARTE DA MORAL E O FIM DA TEORIA DO DIREITO 89

5.1. O FIM DA TEORIA DO DIREITO

5.2. POR QUE AINDA DISTINGUIR O DIREITO DE OUTROS RAMOS DA MORALIDADE? 95

5.3. SIGNIFICADO E IMPLICAÇÕES DO DIREITO ENTENDIDO COMO PARTE DA MORAL 100

6. CONCLUSÕES 105

7. BIBLIOGRAFIA 108 


\section{INTRODUÇão}

\subsection{O QUE LEGITIMIDADE TEM A VER COM DIREITO?}

Existe uma obrigação de obedecer ao direito? É possível responder a essa questão sem termos, antes, uma compreensão clara de o que o direito é?

Parece natural uma resposta negativa a essa segunda pergunta. Não é evidente, afinal, que precisamos primeiro definir o que é o direito para, depois, respondermos se ele é capaz de impor obrigações?

A divisão do trabalho em relação a essas questões também seria natural. A definição de o que é o direito é tarefa da filosofia do direito, apresentada em cursos de Introdução ao Estudo do Direito, e justifica sua própria existência como disciplina. A capacidade do direito de gerar obrigações é questão da filosofia política, disciplina especulativa e estranha à formação de um jurista.

Assim, por exemplo, a teoria do direito ${ }^{1}$ indicará que o direito é um sistema de normas relacionadas a fatos como votações no Congresso Nacional e diferentes teorias procurarão analisar se esse direito cumpre ou não os requisitos que elas colocam - "Houve consentimento?”, “Os cidadãos são tratados com igualdade?", etc. - para o surgimento de uma obrigação moral de obedecer.

É possível, entretanto, que a relação entre essas duas questões tome outra forma e essa possibilidade é o objeto deste trabalho. A identificação do direito (em geral e em casos concretos) pode não ser independente da questão da existência da obrigação de obedecê-lo.

Mais especificamente, a hipótese que pretendo explorar é que nossa pergunta sobre a natureza e o conteúdo do direito é uma pergunta também sobre que natureza e que conteúdo seriam capazes de justificar o uso da força pelo estado. ${ }^{2}$ Dessa forma, a própria definição de

\footnotetext{
${ }^{1}$ Não faço distinção entre "filosofia do direito" e "teoria do direito" neste trabalho. Sobre como essas duas expressões já designaram empreendimentos diferentes, mas que tendem a se confundir a partir do século XX, cf. MACEDO JR., R. P. Teoria, Filosofia e Dogmática Jurídica: Rigor e Método. In: MACEDO JR., R. P. (org.). Teoria do Direito Contemporânea. Curitiba: Juruá Editora, 2017., p. 27-29.

${ }^{2}$ Nesse sentido, tratando de Hobbes e Kant, Nigel Simmonds observa que "when writers such as Hobbes and Kant offer claims about the nature of law, they are addressing the question of what law must be if it is to be capable of justifying the use of force" (SIMMONDS, N. Law as a Moral Idea. Oxford: Oxford University Press, 2007, p. 138)
} 
o que o direito é dependeria de uma resposta à questão de o que lhe pode dar legitimidade, entendida como a capacidade de gerar uma obrigação ${ }^{3}$ de obedecer ao direito com um correlato direito do estado de governar e utilizar a força para garantir a conformidade às normas que ele edita. ${ }^{4}$

Essa sugestão pode soar como uma petição de princípio ou falta de rigor. Mais uma vez, como seria possível perguntar sobre a existência da obrigação de obedecer ao direito sem termos, antes, a definição de qual é a natureza e conteúdo do direito?

Trata-se, porém, da abordagem da teoria do direito de Ronald Dworkin, que entende que a questão de qual é a natureza e o conteúdo do direito será respondida, pelo menos parcialmente, pelo mesmo tipo de consideração moral que aparece em uma investigação sobre a obrigação de obedecer ao direito. Consequentemente, a divisão de trabalho entre filosofia do direito e filosofia política ficaria prejudicada. ${ }^{5}$ Explicarei neste trabalho o que isso significa e quais podem ser suas implicações.

\footnotetext{
${ }^{3}$ Stephen Perry sugere que a legitimidade poderia ser melhor descrita como um "poder" (do Estado) a que corresponde uma "sujeição" (dos cidadãos) e não como uma capacidade de gerar uma obrigação (PERRY, Law and Obligation, p. 273); mantenho, porém, a correlação entre legitimidade e obrigação porque não vislumbro que essa sugestão de Perry faça diferença ao argumento que vou desenvolver.

Neste ponto, estou de acordo com Leslie Green: "It [law] also secures rights, confers powers, defines terms, and so forth. While it would be wrong to suggest that these can somehow be reduced to obligations, it is none the less true that they can only be fully understood with reference to them. To grasp the significance of the power to contract, for example, one must understand that it gives rise to duties to perform or pay damages. To understand the right to free speech, one must see that it grounds in others a duty not to silence. To understand the definition of a 'minor' one must understand the obligations from which such persons are exempt, and those they are powerless to create or change." (GREEN, L. Law and Obligations. In: COLEMAN, J. L.; HIMMA, K. E.; SHAPIRO, S. J. The Oxford Handbook of Jurisprudence and Philosophy of Law. Oxford: Oxford University Press, 2004, p. 515).

4 Trato "legitimidade" como "capacidade de gerar uma obrigação de obedecer ao direito" (DWORKIN, R. Law's Empire. Oxford: Hart Publishing, 1998, p. 191; cf. também DWORKIN, R. Response. Boston University Law Review, v. 90, n. 1059, 2010, p. 1075), o que já pressupõe a chamada "tese da inseparabilidade" entre existir uma obrigação de obedecer ao direito e ser justificada a coerção estatal (EDMUNDSON, W. A. State of the Art: The Duty to Obey the Law. Legal Theory, v. 10, n. 4, Dezembro 2004, p. 220) Uma outra possibilidade seria adotar uma definição mais neutra de legitimidade, como a de justificação do estado para o uso da coerção (i.e., independentemente de existir uma obrigação de obedecer pelos cidadãos), o que não faço já que apenas em situações extremas seria possível que um Estado estivesse justificado a utilizar a força contra alguém que não descumpriu nenhuma obrigação (e.g., submeter alguém suspeito de ter uma doença a quarentena) (PERRY, Law and Obligation, p. 267) e que "um governo que reivindica ter autoridade legítima reivindica, no mínimo, possuir um poder de obrigar seus cidadãos” (PERRY, ibid., p. 265, tradução minha, assim como todas as citações seguintes de obras originais em língua estrangeira).

Ressalvo, ainda, que uso um sentido normativo de legitimidade: "In contrast to Weber's descriptive concept, the normative concept of political legitimacy refers to some benchmark of acceptability or justification of political power or authority and-possibly_obligation" (FABIENNE, P. Political Legitimacy. The Stanford Encyclopedia of Philosophy (Summer 2017 Edition), 2017. Disponivel em: $<$ https://plato.stanford.edu/archives/sum2017/entries/legitimacy/>)

5 "By its insistence on a close interconnection between legal and political theory, Ronald Dworkin's jurisprudence challenges a traditional division of labour. It denies that the question of political obligation-
} 
Para destacar que o argumento de Dworkin não tem nada de trivial e para testar sua consistência, irei contrapô-lo à teoria do direito de Joseph Raz, especialmente sua "tese das fontes", que dissocia a questão da identificação do direito de qualquer investigação sobre sua legitimidade. ${ }^{6}$

\subsection{TEORIAS SOBRE A OBRIGAÇÃO POLÍTICA E TEORIA DO DIREITO}

As teorias da obrigação política ${ }^{7}$ podem ser categorizadas ${ }^{8}$ em teorias da obrigação política como obrigação natural - que se aplicariam a nós independentemente de qualquer ato voluntário, como a teoria de John Rawls sobre o dever de apoiar e se adequar a instituições justas ${ }^{9}$-, teorias da obrigação política como obrigação voluntária - que relacionam a obrigação política a algum ato ou série de atos, como a teoria de John Locke de que haveria um consentimento tácito ao se manter a residência em um território - e teorias da obrigação política como obrigação associativa - derivadas da relação de alguém com uma associação de pessoas.

Para os objetivos deste trabalho, não interessa a análise das nuances, argumentos e contra-argumentos pertinentes às teorias que fazem parte de cada uma dessas categorias. $\mathrm{O}$ importante é destacar como são construídas. Elas partem do pressuposto de que o direito que

whether or not there is a moral obligation to obey the law — can be strictly severed from the question of how the law's content can be determined. The true content of law is itself at least partly determined by moral considerations also pertinent to the existence of an obligation of obedience." (ALLAN, T.R.S. Law, Justice and Integrity: The Paradox of Wicked Laws, Oxford Journal of Legal Studies, Vol. 29, No. 4, 2009, p. 705)

${ }^{6}$ Uma posição intermediária entre as teorias de Dworkin e Raz é representada pelo chamado "positivismo inclusivo". W. J. Waluchow, um de seus mais importantes representantes, apresenta sua teoria expressamente como “a positivistic theory to be found somewhere between Raz's exclusive positivism and Dworkin's (natural) law as integrity” (WALUCHOW, W. J. Inclusive Legal Positivism. Oxford: Clarendon Press, 1994, p. 3). Responderei também a alguns de seus argumentos nos capítulos 2 e 3.

${ }^{7}$ Utilizarei o termo "obrigação política" como sinônimo de "obrigação de obedecer ao direito", apenas pela brevidade e porque são geralmente utilizados intercambiavelmente.

Esse uso indistinto é prevalecente, embora possa ser criticado, afirmando-se que a obrigação política engloba, além da obrigação de obedecer ao direito, também obrigações como a de defender o estado e de dar prioridade a compatriotas (EDMUNDSON, State of the Art: The Duty to Obey the Law, p. 217). O próprio Dworkin parece fazer essa distinção, ao afirmar que a obrigação política "inclui uma obrigação de obedecer ao direito" (DWORKIN, Law's Empire, p. 206, grifo meu), que é feita expressamente por Raz (RAZ, J. The Problem of Authority: Revisiting the Service Conception. In: Between Authority and Interpretation: On the Theory of Law and Practical Reason. Oxford: Oxford University Press, 2009, p. 127). Não adoto a distinção, entretanto, apenas por praticidade e já que "em nenhuma teoria plausível a obrigação política não inclui a obrigação de obedecer ao direito" (GREEN, Law and Obligations, p. 545). Ressalvo que, caso fosse distinguir as expressões, meu objeto aqui seria apenas a "obrigação de obedecer" e não a "obrigação política" nesse sentido mais amplo.

${ }^{8}$ As categorias são de EDMUNDSON, State of the Art: The Duty to Obey the Law, p. 229 e ss.

${ }^{9}$ RAWLS, J. A Theory of Justice. Cambridge: Belknap Press, 1999, p. 117. 
se teria obrigação de obedecer é um conjunto de normas estabelecido de forma mais ou menos clara, em geral com base em alguma referência convencional. Perguntam, então, se esse direito assim identificado deve ser obedecido pelos cidadãos com base nos requisitos específicos a cada teoria ${ }^{10}$. Não por acaso, geralmente a resposta é negativa: não há uma obrigação de obedecer a tais normas ${ }^{11}$.

Dworkin também tem uma teoria da obrigação política. Para ele, uma comunidade ${ }^{12}$ que aceite o que ele chama de "integridade" como seu ideal político constitutivo é capaz de fazer surgir uma obrigação de obedecer para os seus cidadãos. ${ }^{13}$ Se nenhuma interpretação plausível das práticas dessa comunidade permitir que se afirme que esse requisito foi atendido, não haverá obrigação política ${ }^{14}$ e deve ser adotada uma posição cética ${ }^{15}$.

Assim apresentada, a teoria de Dworkin não parece ter nada de especial: é apresentado um requisito - a integridade - para a existência de uma obrigação política e cabe ao teórico ocupado de definir se essa obrigação existe ou não em uma comunidade específica analisar se seu direito cumpre ou não tal requisito. Mas, na verdade, há uma diferença fundamental: a integridade não é apenas a resposta à pergunta sobre a existência de uma obrigação de obedecer, ela é, também, parte da resposta à pergunta “o que é o direito?”. O

\footnotetext{
${ }^{10}$ Como observa Stephen Perry, “[t]hey [as teorias da obrigação política] assume that law constitutes a system of norms the existence and content of which can be established by, say, looking to certain kinds of social facts, and then asking whether or not a given legal system meets a set of independently specifiable conditions; if these conditions are met, then a general obligation to obey is said to exist" (PERRY, Stephen. Associative Obligations and the obligation to obey the law. in HERSHOVITZ, Scott (ed.). Exploring Law's Empire: The Jurisprudence of Ronald Dworkin, Oxford: 2008, p. 2); no mesmo sentido STRAVOPOULOS, N. Legal Interpretivism. Stanford Encyclopedia of Philosophy, 2014. Disponivel em: $<$ https://plato.stanford.edu/entries/law-interpretivist/ >. Acesso em: setembro 2017, p. 3.

${ }^{11}$ GREEN, Law and Obligations, p. 516 e 540. Essa predominância da visão cética pode ser creditada a John Simmons: "The positive accounts typically acknowledge the influence of John Simmons's 1979 book, Moral Principles and Political Obligations, which built so impressive a negative case that it is no exaggeration to say that the literature of the intervening quarter-century has largely consisted of efforts to overcome or deflect Simmons's objections" (EDMUNDSON, State of The Art: The Duty to obey the law, p. 228)

${ }^{12}$ A referência a uma comunidade ao invés de ao Estado não é sem consequências. A obrigação de obediência é devida ao conjunto de indivíduos que forma essa comunidade. "Estado" será apenas uma "personificação útil”" dessa comunidade. (DWORKIN, R. Replies. In: BURLEY, J. (ed.) Dworkin and his critics - with replies by Dworkin. Oxford: Blackwell Publishing, 2004, p. 378)

${ }^{13}$ DWORKIN, Law's Empire, p. 211.

${ }^{14}$ DWORKIN, Justice for Hedgehogs, p. 323

${ }^{15}$ Como afirma Dworkin, ao tratar da interpretação de instituições associativas em geral: “There is no guarantee, however, that the interpretive attitude will always justify reading some apparently unjust feature of an associative institution out of it. [...] The best interpretation may be a deeply skeptical one: that no competent account of the institution can fail to show it as thoroughly and pervasively unjust, and that it should therefore be abandoned. Someone who reaches that conclusion will deny that the practice can impose genuine obligations at all" (DWORKIN, Law's Empire, p. 203). Voltarei a essa questão do ceticismo na seção 3.3.1 e explicarei melhor o que Dworkin entende por "interpretação" no Capítulo 4.
} 
direito como integridade é a teoria do direito de Dworkin, a teoria que dará os critérios para definirmos quando uma proposição jurídica é verdadeira e quando não é. ${ }^{16}$

Ou seja, o mesmo tipo de consideração de moralidade política utilizado para fundamentar uma obrigação de obedecer é, em última instância, utilizado para identificar quais são os critérios de verdade de proposições jurídicas. Para responder, por exemplo, se é verdadeira a proposição de que "o direito brasileiro admite prisão antes do trânsito em julgado" ${ }^{17}$ precisamos passar pelo mesmo tipo de consideração que responde à pergunta sobre se há uma obrigação de obedecer ao direito brasileiro.

Nesse sentido, a afirmação de que, não sendo possível fundamentar a obrigação política, restaria apenas uma posição cética significa que, nessas condições, nenhuma proposição jurídica pode ser correta ou incorreta ${ }^{18}$, isto é, que, se completamente desprezado o ideal de integridade por um estado, então não teríamos mais nenhum padrão de correção para julgar o que está de acordo com o direito e o que não está. Nesse caso, como argumentarei no capítulo 3, a identificação do direito perderá qualquer importância prática.

\subsection{POR QUE DWORKIN?}

Ronald Dworkin é um dos autores fundamentais da teoria do direito do século XX e pautou as discussões na área desde a inauguração do assim chamado "debate HartDworkin"19. Mesmo assim, ele pode ser descrito como uma espécie de outsider, "não escondendo sua visão de que considera muito do trabalho da filosofia do direito

\footnotetext{
${ }^{16}$ Mais especificamente, "According to law as integrity, propositions of law are true if they figure in or follow from the principle of justice, fairness, and procedural due process that provide the best constructive interpretation of the community's legal practice" (DWORKIN, Law's Empire, p. 225).

${ }^{17}$ O Supremo Tribunal Federal já decidiu que sim (HC 126292, Relator(a): Min. TEORI ZAVASCKI, Tribunal Pleno, julgado em 17/02/2016, PROCESSO ELETRÔNICO DJe-100 DIVULG 16-05-2016 PUBLIC 17-05-2016)

${ }^{18}$ Uma posição de "ceticismo interno" em relação a um dado sistema jurídico, no sentido do capítulo "Internal Skepticism" de Justice for Hedgehogs (DWORKIN, R. Justice for Hedgehogs. Cambridge: Belknap Press, 2011, p. 88-96).

19 “'[...] o pensamento jurídico de Ronald Dworkin 'agendou' o debate teórico jurídico durante os anos 19801990. As suas críticas ao positivismo jurídico (tornadas célebres pelo assim denominado "debate HartDworkin") e ao pragmatismo jurídico americano o inseriram no centro das principais polêmicas teóricojurídicas das últimas décadas. Nesse sentido, os seus trabalhos fixaram a agenda das discussões e dos problemas teóricos que passaram a ser dominantes nos foros acadêmicos e teóricos." (MACEDO JUNIOR, R. P. Do Xadrez à Cortesia: Dworkin e a Teoria do Direito Contemporânea. Tese de Livre Docência, USP Faculdade de Direito. São Paulo. 2012, p. 20)
} 
desinteressante ou mesmo mal orientado" ${ }^{20}$. Ao mesmo tempo, Dworkin tem a qualidade e a importância de seu trabalho continuamente questionadas, disputando-se, inclusive, se sua teoria é do mesmo gênero da de seus pares. ${ }^{21}$

Penso que a razão para essa desconfiança está em uma má compreensão - ou em uma forte discordância - em relação ao ponto central da tese de Dworkin sobre interpretação no direito: a afirmação de que cada teoria do direito pressupõe uma concepção diferente de obrigação política (ou a impossibilidade dessa obrigação) e que as grandes divergências entre essas teorias são, na verdade, divergências sobre legitimidade ${ }^{22}$.

É compreensível que essa desconfiança ganhe ainda mais força quando consideramos que Dworkin também afirma que as divergências na prática jurídica - sobre a verdade de proposições determinadas, do tipo "o direito brasileiro permite cotas raciais" - também podem ser reportadas a divergências sobre legitimidade. É por essa visão um tanto heterodoxa de Dworkin sobre o que é fazer filosofia do direito ${ }^{23}$ que ele foi o autor escolhido como referência para esse trabalho, que tem como tema justamente a relação entre legitimidade e interpretação.

\subsection{POR QUE RAZ?}

Joseph Raz é, assim como Dworkin, um dos protagonistas do debate contemporâneo em teoria do direito. Em Oxford, foi aluno de Herbert Hart, de quem se tornou "herdeiro incontestável" 24 , elaborando a teoria do direito positivista mais influente desde a apresentada em $O$ Conceito de Direito ${ }^{25}$.

\footnotetext{
${ }^{20}$ PRIEL, D. The Place of Legitimacy in Legal Theory. McGill Law Journal, v. 1, n. 57, 2011, p. 3.

${ }^{21}$ PRIEL, The Place of Legitimacy in Legal Theory, p.3.

${ }^{22}$ Como resume Stephen Perry, "Different theories of law presuppose different theories of political obligation (or else deny that there can be such a theory). To determine which theory of law is correct we must, therefore, at some point address the general question of political obligation, and this necessarily takes us deep into issues of substantive political morality. This is, I believe, the nerve of Dworkin's general theory of interpretation, understood as a methodology for doing philosophy of law" (PERRY, Associative obligations and the obligation to obey the law, p. 8)

${ }^{23}$ Como nota Hart, ao explicar o motivo de ter escolhido Dworkin como seu principal adversário no pós escrito a seu O Conceito de Direito: "he [Dworkin] has not only argued that nearly all the distinctive theses of this book are radically mistaken, but he has called in question the whole conception of legal theory and of what it should do which is implicit in the book" (HART, The Concept of Law, p. 239)

${ }^{24}$ COLEMAN, J. Law and Political Morality. APA Newsletters (Newsletter on Philosophy and Law), v. 6 , n. 2, 2007, p. 7

${ }^{25}$ POSTEMA, G. A treatise of legal philosophy and general jurisprudence. New York: Springer, v. 11, 2011, p. 348.
} 
A "tese das fontes" proposta por Raz, segundo a qual a identificação do direito deve ser feita exclusivamente através de fatos $^{26}$ dissocia a identificação do direito de qualquer pergunta sobre sua justificação. Essa proposta, oposta à de Dworkin, não deve parecer incomum. Pensar o direito como relacionado estritamente a questões de fato - "deputados votaram", "Presidente sancionou”, “juiz sentenciou”, “Tribunal reformou” - é parte de um “esquema mental" que faz parte do senso comum do jurista ${ }^{27}$.

Ainda assim, a teoria do direito de Raz parece ser justamente o que Dworkin diz que uma teoria do direito não deveria ser. Mais do que equivocada em suas conclusões, ela toma para si objetivos e estabelece métodos que, considerados os argumentos de Dworkin, simplesmente não fariam sentido.

Para dar apenas um exemplo textual dessa divergência: após resumir em algumas linhas os argumentos de Raz sobre a centralidade do conceito de "autoridade" na identificação do direito, Dworkin observa que, mesmo assim resumido, o argumento de Raz deve "parecer estranho" ao leitor, pois é importante, prática e politicamente, determinar o que os juízes podem e devem fazer no exercício de sua responsabilidade de aplicar o direito e seria "bizarro" que esse ponto crucial fosse "baseado em uma análise abstrata do conceito de autoridade" 28 .

Mas, como veremos, Raz constrói sua teoria de forma engenhosa. Ele defende o tipo de análise conceitual em que ela se baseia. De forma semelhante ao que faz Dworkin, ele afirma que "a teoria do direito é uma parte da filosofia prática, aplicada a uma instituição social" 29 e não nega a relação entre o direito e a moralidade; ao contrário, afirma que o direito reivindica autoridade legítima ${ }^{30}$, pretendendo modificar a moralidade ${ }^{31}$. Mas, de forma oposta a Dworkin, defende que apenas podemos dar sentido a essa reivindicação se dissociarmos a identificação do direito de considerações de moralidade política, fazendo-a depender apenas de fatos.

\footnotetext{
${ }^{26}$ RAZ, Authority, Law and Morality, p. 231-235.

${ }^{27}$ MACEDO JR., R. P. O direito em desacordo: o debate entre o interpretativismo e o convencionalismo jurídico. São Paulo: Tese apresentada ao concurso de Professor Titular - Departamento de Filosofia e Teoria Geral do Direito - USP, 2013, p. 216, tratando do convencionalismo e da "tese das fontes sociais" em geral.

${ }^{28}$ DWORKIN, Thirty Years On, p. 198-199

${ }^{29}$ RAZ, Practical Reason and Norms, p. 149

${ }^{30}$ RAZ, J. The Claims of Law. In: ed. Oxford: Clarendon Press, 2009, p. 30

${ }^{31}$ RAZ, J. Incorporation by Law. Legal Theory, Cambridge, n. 10, 2004, p. 1.
} 
Entender a divergência entre os dois autores demanda, portanto, mais elaboração. Especialmente, a teoria de Raz não pode ser descrita como um positivismo vulgar desatento à prática jurídica. Como já observei, sua teoria, na verdade, pode parecer bastante atraente ao senso comum de juristas. A escolha desse autor se justifica, assim, por sua teoria oferecer um desafio original, influente e radical às proposições de Dworkin a respeito da centralidade da legitimidade na interpretação do direito.

\subsection{OBJETIVOS E ORGANIZAÇÃO DO TRABALHO}

Apresentada a possível relação entre teorias da obrigação política e teoria do direito e a importância de Dworkin e Raz para a análise dessa questão, quero deixar mais claros os objetivos deste trabalho.

Para Dworkin, uma teoria genuína sobre o direito é, na verdade, uma teoria normativa (no sentido de não meramente descritiva, mas engajada). Isso pode parecer muito abstrato até que entendamos a que essa normatividade se refere. Se teorias do direito são teorias sobre um esquema de direitos e obrigações que permitem a coerção estatal legítima ${ }^{32}$, então a disputa sobre a melhor teoria do direito será uma disputa sobre o que pode dar legitimidade a essa coerção.

Naturalmente, não é assim que os positivistas veem suas próprias teorias do direito, que pretendem descritivas. Mas quando olham para a teoria de Dworkin sem perceber a relação que ele afirma existir entre legitimidade e interpretação, acabam fazendo uma leitura equivocada, notadamente compreendendo-a como uma teoria sobre quais são os requisitos de validade de proposições jurídicas. ${ }^{33}$

\footnotetext{
${ }^{32}$ DWORKIN, Law's Empire, p. 93

33 "Positivists disagree among themselves on many questions, but as a first cut what unites all of them is that they treat the question of validity as prior to and distinct from the question of content. And they often assume that this picture is shared by all legal theorists." (PRIEL, The Place of Legitimacy, p. 7). Priel aponta que isso é feito explicitamente por Andrei Marmor ("Basically, the dispute [between positivists and non-positivists] is about the conditions of legal validity", Legal Positivism: Still Descriptive and Morally Neutral" (2006) 26:4 Oxford J Legal Stud 683, p. 689) e Brian Leiter ("When lawyers or judges have a theoretical disagreement about law in Dworkin's sense, they are disagreeing about what most legal philosophers call the criteria of legal validity ....", Explaining Theoretical Disagreement" (2009) 76:3 U Chi L Rev, p. 1216) (PRIEL, ibid.). Voltarei a essa questão no Capítulo 3.
} 
Outro erro derivado da não percepção da relação entre legitimidade e interpretação na teoria de Dworkin é o foco excessivo em sua distinção entre princípios e $\operatorname{regras}^{34}$ e a compreensão de sua crítica ao positivismo como uma crítica de que os princípios não poderiam cumprir os requisitos de validade do positivismo, quando, na verdade, o argumento de Dworkin está baseado no tipo de justificação moral que os princípios exigem ${ }^{35}$.

Um dos objetivos do trabalho é apontar o erro dessas leituras da teoria do direito de Dworkin, que, de diferentes formas, ainda a veem como uma teoria preocupada com descrições e classificações, como uma "fenomenologia descritiva" ou uma "teoria do direito taxonômica"36.

Mais importante, perceber que os desacordos em teoria do direito podem ser compreendidos como desacordos políticos e com influência direta na prática jurídica permite que a teoria do direito sirva, de fato, ao esclarecimento de tais desacordos e à orientação sobre o que os juristas (e os cidadãos) devem fazer ${ }^{37}$; ou seja, à orientação sobre como o direito deve ser interpretado. Destacar e defender esse componente central da teoria do direito de Dworkin é o principal objetivo deste trabalho.

O próximo capítulo apresenta a "tese das fontes" de Joseph Raz, que dissocia a identificação e a justificação do direito e, penso, pode oferecer alguns dos mais poderosos argumentos para, contra Dworkin, fundamentar o tipo de análise do direito subjacente às teorias da obrigação política identificadas na Seção 1.2, acima.

\footnotetext{
34 “Entre muitos, Dworkin ainda é conhecido como o autor da distinção entre regras e princípios. Segundo uma visão mais simplória e escolar, ele é muitas vezes qualificado como uma espécie de 'inventor' da distinção, o que é, evidentemente, uma impropriedade" (MACEDO Jr., O direito em desacordo, p. 25)

35 "A forma como Dworkin formulou a sua objeção estimulou a expansão de um longo e prolífico debate entre ele e os positivistas que, ao meu ver, nem sempre se dirigiu ao ponto central de sua crítica. Isso porque a essência de sua objeção não versava sobre a falta de referência ou sobre o 'esquecimento' dos princípios (tal como tradicionalmente compreendidos pela dogmática jurídica) na descrição do que é o direito, mas sim sobre o fato de que os princípios são parâmetros (ou regras, em sentido amplo) que exigem justificação moral." (MACEDO Jr., O direito em desacordo, p. 35-36). Sobre isso, cf. DWORKIN, R. The Concepts of Law. In: Justice in Robes. Cambridge: Harvard Belknap Press, 2006, p. 234.

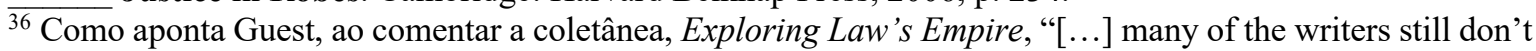
fully grasp what I think must have been obvious before even the publication of Law's Empire in 1986 but certainly after it, that Dworkin is not engaged in descriptive phenomenology (or, as he calls it "taxonomic jurisprudence"). Dworkin's idea that law is a subset of morality, coupled with his account of the unity of value, is powerful and compelling. It is "liberating" as he rather grandly says in Justice for Hedgehogs." (GUEST, Ronald Dworkin, p. vii-viii)

${ }^{37}$ DWORKIN, R. Hart's Postscript and the Point of Political Philosophy in Justice in Robes. Cambridge: Belknap Press, 2006, p. 186.
} 
No Capítulo 3, trato dos argumentos de Dworkin no sentido contrário. Destacarei como, para ele, definir quais proposições jurídicas são corretas - desde saber se é verdadeiro que "o direito brasileiro proíbe trafegar a $130 \mathrm{~km} / \mathrm{h}$ na Rodovia dos Bandeirantes" até se "o direito brasileiro admite o casamento homoafetivo" - depende de definir quais padrões de correção reforçam a legitimidade do estado e, consequentemente, a obrigação dos cidadãos de obedecer ao seu direito.

No capítulo 4, apresentarei o argumento de Dworkin sobre qual seria a raiz do erro positivista, o argumento conceitual de que o conceito de direito é uma espécie do que ele chama de conceito interpretativo, que pode ser compreendido apenas com referência ao propósito que é a ele atribuído, e que o positivismo cria teorias falhas ao tentar explicar o conceito de direito como o que ele chama de conceito criterial, que é compreendido através de uma referência convencional.

No capítulo 5, tratarei de como Dworkin reformulou sua teoria afirmando não que o direito e a moral são independentes nem que a moral é parte do direito, mas fazendo a afirmação aparentemente extravagante de que o direito é parte da moral. A partir disso, enfrentarei a questão de se ainda temos alguma razão para diferenciar direito e moralidade, respondendo ao argumento de Scott Hershovitz em The End of Jurisprudence ${ }^{38}$.

Por fim, apresentarei algumas conclusões, defendendo que uma teoria do direito consciente do papel justificatório que o direito tem deve se preocupar com a questão da legitimidade, não sendo possível a construção de uma teoria do direito meramente descritiva como pretende Raz.

Passos seguintes na pesquisa seriam responder (i) se temos ou não uma obrigação de obedecer ao direito e quais seriam as melhores teorias para fundamentar essa obrigação e (ii) o que essas teorias exigiriam na prática. Considerando Joseph Raz e Ronald Dworkin, isso significaria perguntar, respectivamente, se a tese da justificação normal e a integridade são capazes de fundamentar uma obrigação de obedecer ao direito e o que elas exigem das autoridades (juízes, inclusive) e dos cidadãos em geral. Ressalvo que não darei esses passos. A dissertação será limitada, nos termos apresentados acima, à pergunta sobre qual é a relação entre a identificação do direito e sua justificação. 
Outra limitação do trabalho é que não pretendo reconstruir toda - e sequer a maior parte - das teorias do direito de Raz e Dworkin. O foco é apenas naquilo que interessa ao problema de pesquisa. Isso é especialmente importante no que diz respeito a Dworkin, cuja obra é em grande parte uma defesa de sua concepção de direito como integridade. Com isso, meu foco será, quanto a Raz, em seu argumento sobre a tese das fontes e, quanto a Dworkin, em sua compreensão do direito como justificação para a coerção estatal. 


\section{DesCreVer SEM JUSTIFICAR: A TeSe DAS FonTES DE JOSEPH RAZ}

Raz afirma que é uma característica essencial do direito que ele reivindique autoridade legítima ${ }^{39}$ e que "o direito consiste apenas em considerações autoritativas positivistas" ${ }^{40}$. Quero, inicialmente, explicar como ele chega a essas conclusões. Para isso, apresentarei (2.1) sua noção de autoridade, (2.2) a relação que ele faz entre direito e autoridade e (2.3) seu argumento sobre por que, para ter autoridade, o direito precisa ser identificado independentemente da moral - a tese das fontes.

Também tratarei (2.4) do argumento de Raz sobre a obrigação de obedecer ao direito. Apesar de estar fora de sua teoria do direito, naturalmente se trata de um argumento referente à obrigação de obedecer ao direito segundo um conceito raziano de direito, cuja apresentação já servirá para indicar consequências da adoção de uma teoria como a tese das fontes.

Assim, em seguida, tratarei, (2.5) de qual pode ser a função de uma teoria do direito construída dessa forma e, por fim, destacarei, mais diretamente, (2.6) como as conclusões de Raz implicam uma diferença radical entre o que o direito exige e o que pode ser justificado.

\subsection{O QUE É AUTORIDADE?}

Raz trabalha com algumas categorias de razões que precisamos entender para compreendermos seu conceito de autoridade: razões de primeira ordem e razões de segunda ordem, estas subdivididas em razões de segunda ordem positivas e em razões de segunda ordem negativas (ou exclusionárias).

\footnotetext{
${ }^{39}$ Para Raz, o conceito de "autoridade legítima" está pressuposto no conceito de "autoridade de fato", pois este depende de que a reivindicação do governo de que sua autoridade é legítima seja aceita por um número suficiente de pessoas poderosas para garantir que ele controle uma determinada área. (RAZ, The Claims of Law, p. 28)

${ }^{40}$ No original "Law consists only of authoritative positivist considerations" (RAZ, J. The Problem about the Nature of Law. In: Clarendon Press, 1995, p. 206)
} 
Razões de primeira ordem são razões para agir ${ }^{41}$. Razões de segunda ordem são razões para agir por uma razão (razões de segunda ordem positivas) ou para não agir por uma razão (razões de segunda ordem negativas, ou razões exclusionárias [exclusionary reasons]). Esquematicamente:

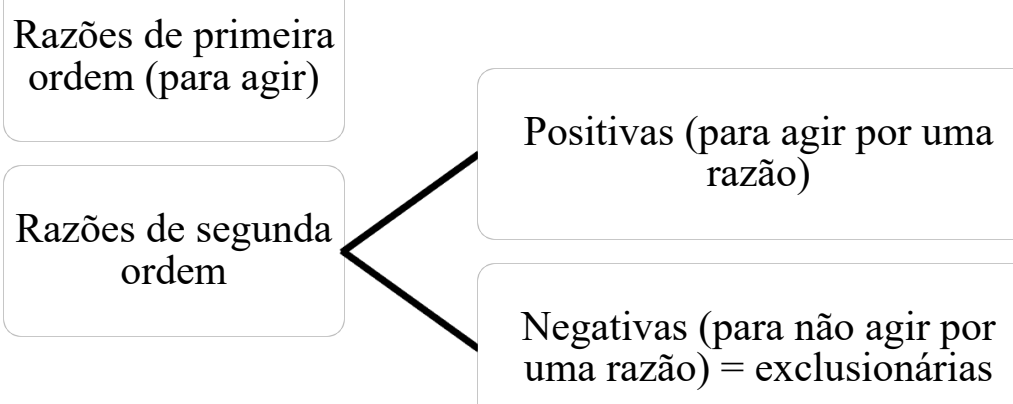

No exemplo de Raz, as ordens de uma mãe são razões (de primeira ordem) para seu filho agir; se o pai diz a seu filho que ele deve obedecer a sua mãe, ele está colocando uma razão para o filho agir por uma razão, ou seja, uma razão de segunda ordem. ${ }^{42}$

Há, ainda, casos em que um fato é ao mesmo tempo uma razão (de primeira ordem) para agir e uma razão (de segunda ordem) para desconsiderarmos razões contra ela. Esses fatos são chamados por Raz de razões protegidas [protected reasons] ${ }^{43}$, ou razões preemptivas $^{44}$ e são, como veremos, uma categoria fundamental para entendermos como o direito funciona. As razões protegidas ou pre-emptivas não se somam às outras razões que o indivíduo tem para agir - que Raz chama de razões dependentes. Elas excluem essas razões

${ }^{41} \mathrm{O}$ conceito de "razão para agir" é amplo: "A reason for an action is a consideration that renders its choice intelligible, and counts in its favour" (RAZ, The Problem of Authority, p. 129) ou "The reason for an action are considerations which count in favour of that action" (RAZ, J. Postscript to the Second Edition: Rethinking exclusionary reasons. In:

Practical Reason and Norms. Oxford: Oxford University Press, 1999, p. 186)

42 RAZ, J. Legitimate Authority. In: The Authority of Law: Essays on Law and Morality. 2nd edition. ed. Oxford: Clarendon Press, 2009, p. 17.

43 " [...] sometimes the same fact is both a reason for an action and an (exclusionary) reason for disregarding reasons against it. I shall call such facts protected reasons for an action" (RAZ, Legitimate Authority, p. 18).

44 Tomarei "razões protegidas" e "razões preemptivas" como sinônimos. Na nota de rodapé n. 21 de The Morality of Freedom (p. 42), Raz se refere ao capítulo 1 do livro The Authority of Law dizendo que, lá, ele "explained some of the formal features of pre-emptive reasons"; no referido capítulo, entretanto, ele usa somente a expressão "exclusionary reasons", jamais "pre-emptive reason”. 
dependentes e tomam seu lugar ${ }^{45}$. Isto é, não há uma competição entre razões com “diferentes pesos", há uma exclusão. ${ }^{46}$

Um exemplo seria de duas pessoas que têm uma controvérsia sobre o cumprimento de um contrato e decidem submetê-la a um árbitro. Inicialmente, cada uma dessas pessoas tem razões (de primeira ordem) para agir: uma das partes tem razões para cobrar uma indenização. A outra parte tem razões para não pagar nenhuma indenização. Quando o árbitro decidir, sua decisão não será uma razão a mais, que vai se somar às razões das partes. A decisão do árbitro não tem simplesmente "mais peso" que as razões dos que estão submetidos à arbitragem; ela excluirá - ela é uma razão exclusionária - e substituirá - ela também é uma razão de primeira ordem para agir -essas razões dependentes. ${ }^{47} \mathrm{~A}$ decisão do árbitro é, portanto, uma razão protegida.

A partir dessas categorias, Raz constrói seu conceito de autoridade. Seu argumento é que reconhecer o poder de "esvaziamento" [pre-emptiveness] das razões emitidas por determinado agente seria a única forma de reconhecer a sua autoridade. ${ }^{48}$

No caso do árbitro, por exemplo, a única forma adequada de reconhecer sua autoridade é tomá-la como uma razão que substitui as razões dependentes referentes ao cumprimento do contrato que as partes tinham antes de submeter a ele sua controvérsia. ${ }^{49}$ Uma característica fundamental da autoridade é, assim, que ela "transfere a decisão de uma pessoa para outra" ${ }^{\circ 0}$; no caso, das partes para o árbitro. Não reconhecer isso seria permitir que as partes refizessem o trabalho do árbitro, que retomassem a controvérsia que a arbitragem pretendia resolver. ${ }^{51}$

Essa é a intenção das autoridades ao emitir razões: elas as emitem para que sejam entendidas como ordens e ordens são dadas com a intenção de que aqueles que as recebem

\footnotetext{
45 "The fact that an authority requires performance of an action is a reason for its performance which is not to be added to all other relevant reasons when assessing what to do, but should exclude and take the place of some of them". (RAZ, The Morality of Freedom, p. 46)

${ }^{46}$ RAZ, Postscript to the Second Edition: Rethinking exclusionary reasons, p. 189

${ }^{47}$ RAZ, J. The Morality of Freedom. Oxford: Oxford University Press, 1986, p. 41-42

${ }^{48}$ RAZ, J. Authority, Law and Morality. In: RAZ, J. Ethics in the Public Domain: Essays in the Morality of Law and Politics. Oxford: Clarendon Press, 1995, p. 213.

${ }^{49}$ RAZ, The Morality of Freedom, p. 42.

${ }^{50} \mathrm{RAZ}$, Postscript to the Second Edition: Rethinking exclusionary reasons, p. 193

${ }^{51}$ Waluchow critica esse exemplo da arbitragem, afirmando que ela não compartilha com o direito algumas características essenciais, de modo que as conclusões sobre as razões que o árbitro emite não podem ser extrapoladas para o direito (cf. WALUCHOW, Inclusive Legal Positivism, p. 132).
} 
as tomem como razões protegidas, ou seja, razões cujos fundamentos não serão discutidos. ${ }^{52}$ Em outras palavras, as autoridades reivindicam legitimidade, entendida justamente da forma como tratei desse conceito na Introdução: como um direito de governar [right to rule] ${ }^{53}$, um direito de emitir razões vinculantes, a que corresponde um dever de obedecer ${ }^{54}$.

Que tipo de argumento é esse? Não é, para Raz, um argumento moral, mas um argumento conceitual. O erro na afirmação de que aqueles que submeteram a questão à arbitragem sopesam todas as razões para seguir as diretivas do árbitro e todas as razões para não as seguir é um erro conceitual. O correto é descrever as razões emitidas por autoridades como exclusionárias porque essa é a melhor representação da "estrutura de raciocínio que necessariamente está envolvida na reflexão sobre regras autoritativas" ${ }^{55}$, embora, como se verá, as autoridades que reivindicam criar razões exclusionárias possam falhar em criá-las para aqueles que estariam sujeitos a elas.

Tudo isso dito, conclui-se que, considerando a forma como decidimos o que devemos fazer, isto é, considerando como nosso raciocínio prático funciona, a autoridade consiste na possibilidade de emitir ou modificar razões protegidas.

\subsection{AUTORIDADE E DIREITO}

Raz afirma que é uma característica essencial do direito reivindicar ${ }^{56}$ autoridade legítima. Considerando o conceito de autoridade visto acima, isso significa que o direito reivindica que as razões que ele emite têm a capacidade de afastar as razões para a nãoobediência, que ele emite razões exclusionárias:

A reivindicação de autoridade legítima do direito não é apenas uma reivindicação de que as regras são razões. Ela inclui a reivindicação de que elas são razões exclusionárias para não

\footnotetext{
${ }^{52}$ RAZ, Legitimate Authority, p. 22.

${ }^{53}$ RAZ, The Problem of Authority: Revisiting the Service Conception, p. 128

54"The obligation to obey a person which is commonly regarded as entailed by the assertion that he has legitimate authority is nothing but the imputation to him of a power to bind. For the obligation to obey is an obligation to obey if and when the authority commands, and this is the same as a power or capacity in the authority to issue valid or binding directives." (RAZ, The Morality of Freedom, p. 24)

${ }_{55}$ RAZ, Postscript to the Second Edition: Rethinking exclusionary reasons., p. 191-193.

${ }^{56}$ Ao dizer que "o direito" reivindica, Raz quer dizer que os órgãos do estado, especialmente os tribunais, o fazem: "It is useful to avail ourselves of the general habit of personifying the law and talking of what it requires, permits, claims, authorizes, etc. The law requires, permits and claims what the organs of government, acting lawfully, and in particular the courts, say that it does" (RAZ, The Morality of Freedom, p. 70)
} 
levarmos em consideração [disregarding] as razões para a não conformidade [nonconformity]. ${ }^{57}$

É assim que Raz faz a ligação entre seu conceito de autoridade e seu conceito de direito. O direito reivindica autoridade legítima, isto é, reivindica que as razões que ele emite vinculam os que estão sujeitos a ele, que criam uma obrigação de obedecer ${ }^{58}$.

Mesmo quando não parece impor diretamente obrigações - quando não determina que alguém faça ou deixe de fazer alguma coisa -, a natureza autoritativa do direito ainda estaria presente. Por exemplo, uma lei que concede a determinado tipo de entidade personalidade jurídica só tem relevância porque imporá obrigações a essa entidade e àqueles que se relacionam com ela. O conceito de "obrigação" é, assim, central à compreensão de o que é uma autoridade..$^{59}$

A reivindicação de autoridade do direito é também muito ampla. Além de reivindicar que as razões que ele emite são protegidas (e, portanto, criam obrigações), o direito é o mais importante sistema institucionalizado que pode existir em uma sociedade, reivindicando ter legitimidade para regular todos os aspectos da vida das pessoas sujeitas a ele ${ }^{60} \mathrm{e}$ reivindicando ter supremacia sobre quaisquer outros sistemas normativos que se apliquem a essas pessoas $^{61}$. Essa é uma das razões que justificam nossa ênfase na análise da autoridade de governos mesmo em um mundo em que entidades privadas têm cada vez mais poder. Por mais poder que tenha, certamente nenhuma empresa reivindica autoridade sobre todos os aspectos da vida de ninguém. ${ }^{62}$

Até aqui definimos autoridade e relacionamos autoridade ao direito, mas não dissemos se o direito de cada país tem ou não a autoridade legítima que reivindica ter. O fato de um governo não ter a autoridade legítima que reivindica significa que ele não tem direito?

Não. O que vimos até agora sobre a relação entre direito e autoridade não significa que o direito necessariamente tenha autoridade, mas que ele necessariamente reivindica ter

\footnotetext{
${ }^{57}$ RAZ, The Claims of Law, p. 30

${ }^{58} \mathrm{RAZ}$, The Morality of Freedom, p. 24

${ }^{59}$ RAZ, The Morality of Freedom, p. 44-45

${ }^{60}$ RAZ, J. The Institutional Nature of Law. In:

2nd Edition. ed. Oxford: Clarendon Press, 2009, p. 116 -117

${ }^{61} \mathrm{RAZ}$, J. The Uniqueness of Law. In: Press, 1999, p. 151.

${ }^{62}$ RAZ, The Morality of Freedom. p. 4
} 
autoridade. É isso que se deve deduzir do fato de que no direito utilizamos uma terminologia própria da moralidade - falamos em deveres, obrigações, direitos, etc. Essa terminologia, segundo Raz, demonstra não o que o direito é, mas o que ele aspira ser. Ele aspira ser moralmente justificado ou, em outras palavras, ele reivindica ter autoridade legítima ${ }^{63}$ Essa reivindicação aparece em todos os momentos em que algum agente estatal usa o direito como fundamento para afirmar que alguém tem uma obrigação: quando um fiscal cobra um tributo, quando um policial aplica uma multa, quando um juiz determina uma prisão, etc. Quando nos ocupamos de dizer que algo é verdadeiro juridicamente estamos falando de o que seria verdadeiro caso as reivindicações de autoridade legítima que o direito faz fossem verdadeiras. Adotamos o que Raz chama de "ponto de vista relevante" 64.

Por reivindicar ter autoridade legítima, o direito deve ter, pelo menos, a capacidade [can] de ter essa autoridade. Sem essa capacidade, suas reivindicações, mais do que incorretas, seriam ininteligíveis. No exemplo que o próprio Raz dá, se o direito fosse uma série de proposições sobre o comportamento de vulcões certamente lhe faltaria a capacidade de ter autoridade ${ }^{65}$. Ou seja, mesmo que nenhum estado tenha a autoridade que reivindica ter, a identificação do direito com a autoridade dá certos contornos mínimos para o que podem ser sistemas jurídicos. Como se verá a seguir, essa relação entre direito e autoridade também serve à desconsideração da moralidade na identificação do direito.

\subsection{DIREITO E MORALIDADE: A TESE DAS FONTES}

A "tese das fontes" [source thesis] é a teoria que Raz propõe para explicar a relação entre direito e moral. Segundo ela, a identificação do direito deve ser feita exclusivamente através de fatos $^{66}$, como a promulgação de uma lei ou a publicação de um acórdão. Necessariamente todas as normas jurídicas são definidas exclusivamente por fatos como esses. Em uma abordagem mais radical do que a do positivismo de Hart, a tese das fontes

${ }^{63}$ RAZ, J. On The Nature of Law. In: Between Authority and Interpretation. Oxford: Oxford University Press, 2009, p. 111-112.

${ }^{64}$ No exemplo de Raz, a situação é análoga à de um católico especializado em direito rabínico que diz a um judeu o que este deveria fazer "do ponto de vista judeu ortodoxo" (RAZ, J. Legal Validity. In: The Authority of Law: Essays on Law and Morality. 2nd Edition. ed. Oxford: Clarendon Press, 2009, p. 156-157)

${ }^{65}$ RAZ, Authority, Law and Morality, p. 216-217.

${ }^{66}$ RAZ, Authority, Law and Morality, p. 231-235. 
tem como implicação que princípios morais nunca estão incluídos entre os critérios para determinar se uma norma jurídica é válida. ${ }^{67}$

Essa tese deriva da compreensão de Raz, vista acima, de que o direito reivindica autoridade legítima, autoridade que, por sua vez, implica o poder de emitir razões exclusionárias para a obediência. Nas palavras de Raz,

Já que é da essência mesma da pretensa autoridade que ela emita normas [rulings] que são vinculantes independentemente de qualquer outra justificação, segue que deve ser possível identificar essas normas sem engajar-se em argumentos justificatórios, i.e., como decorrentes de certas atividades e interpretadas à luz de padrões publicamente verificáveis que não envolvam argumentos morais. ${ }^{68}$

Essa relação entre a reivindicação de autoridade legítima feita pelo direito e a forma de identificá-lo, através da tese das fontes, merece um pouco mais de atenção. Qual seria o problema de permitir que a identificação do direito, pelo menos em alguns casos, dependesse de alguma consideração de moralidade? Como isso poderia comprometer sua autoridade?

Como visto, Raz afirma que se o direito reivindica autoridade ele deve ter pelo menos a capacidade de ter autoridade. Para ter tal capacidade é preciso que o direito impeça que os que estão sujeitos a ele voltem a questionar aquelas questões que são justamente as que o direito pretendeu resolver. Isso significa que, se havia uma divergência sobre qual seria a alíquota justa para um tributo e uma lei fixa essa alíquota em $10 \%$, então reconhecer autoridade ao direito significa reconhecer que essa nova lei coloca uma razão exclusionária que, aceita, afasta todas as outras razões dependentes, pelas quais a alíquota deveria ser fixada em, por exemplo, 5 ou $20 \%$.

Aceitar que algum critério de justiça pudesse figurar nessa identificação seria negar ao direito a autoridade que ele reivindica ter. Seria permitir que ainda coubesse àquele que está sujeito à autoridade a decisão sobre questões sobre as quais cabia justamente à autoridade decidir, negando a característica fundamental da autoridade de "transferir a decisão de um pessoa para outra". Afinal, se é para continuarmos discutindo se a alíquota

\footnotetext{
${ }^{67}$ POSTEMA, A treatise of legal philosophy and general jurisprudence. Vol. 11, p. 350. Trata-se da diferença entre o que se convencionou chamar de positivismo inclusivista (que admite que princípios morais componham os critérios de validade em um sistema jurídico) e positivismo exclusivista (que não o admite).

${ }^{68}$ RAZ, J. Legal Positivism and the Sources of Law. In: Morality. 2nd Edition. ed. Oxford: Clarendon Press, 2009, p. 51-52

The Authority of Law: Essays on Law and
} 
correta seria de $5 \%$ ou de $20 \%$, qual é o sentido de termos uma regra jurídica que determine que ela é de $10 \%$ ?

Manter esse tipo de discussão seria inconsistente com a autoridade do direito tanto se nos basearmos em critérios de justiça - do tipo "a alíquota deve ser menor porque o produto é essencial" - quanto se nos basearmos em argumentos de coerência com outras regras jurídicas ${ }^{69}$ - do tipo "existe um produto muito semelhante, que tem uma alíquota muito menor e não há razão para essa distinção”.

Com isso, a tese das fontes permitiria identificar uma das funções básicas do direito $^{70}$ : "prover padrões publicamente verificáveis pelos quais se considera que os membros da sociedade estão vinculados de forma que não possam justificar a não-

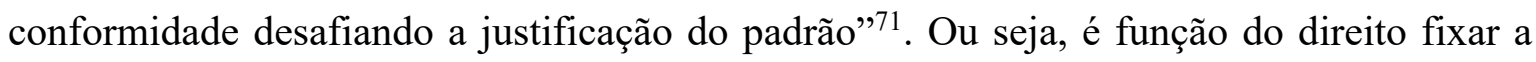
alíquota em $10 \%$, vinculando os contribuintes e impedindo que possam apresentar como justificativa para o não recolhimento do tributo a injustiça ou a incoerência da alíquota fixada.

Uma ressalva importante é que a tese das fontes não significa que os tribunais nunca se baseiam em considerações além dessas fontes. Significa apenas que, quando o fazem, eles não estão aplicando regras jurídicas vinculantes, mas apenas exercendo sua discricionariedade. ${ }^{72}$ Os tribunais são instituições fundamentais para uma compreensão do direito - Raz os chama de "instituições primárias" -, pois, para Raz, o "ponto de vista jurídico" diz respeito justamente às normas que os tribunais devem aplicar ${ }^{73}$, mas a teoria do direito não esgota o que os tribunais fazem, ela não se confunde com uma teoria da adjudicação. Mesmo no caso em que uma regra jurídica incorpora alguma consideração moral ${ }^{74}$, tal consideração não se tornará, por isso, jurídica, do mesmo modo que uma

\footnotetext{
${ }^{69}$ Uma interpretação que busca coerência no direito "fails to make sense of the existence of legal authorities" (RAZ, J. The Relevance of Coherence. Boston University Law Review, v. 72, n. 2, 1992, p. 295)

${ }^{70}$ Sobre como essa "função" não significa a atribuição de um valor (um "point" no sentido dworkiniano), ver MACEDO Jr., R. P. Do Xadrez à Cortesia: Dworkin e a Teoria do Direito Contemporânea. Tese de Livre Docência, USP - Faculdade de Direito. São Paulo. 2012, p. 206-207. Para uma crítica sobre como esse "argumento funcional" poderia levar igualmente a uma defesa de "razões absolutas" e não apenas exclusionárias, ver MURATA, D. P. Em Meio à Tempestade: Valoração e Descrição na Teoria do Direito. Dissertação de Mestrado, USP - Faculdade de Direito. São Paulo. 2018 p. 95.

${ }^{71}$ RAZ, Legal Positivism and the Sources of Law, p. 52

${ }^{72}$ RAZ, J. Legal Reasons, Sources, and Gaps. In:

2nd Edition. ed. Oxford: Clarendon Press, 2009, p. 59

${ }^{73}$ RAZ, The Institutional Nature of Law, p. 113

${ }^{74}$ Por exemplo, "Na aplicação da lei, o juiz atenderá aos fins sociais a que ela se dirige e às exigências do bem comum" (art. $5^{\circ}$, Lei de Introdução às Normas do Direito Brasileiro) e "O juiz não é obrigado a observar critério
} 
remissão da lei brasileira a uma lei estrangeira ${ }^{75}$ não faz com que esta lei estrangeira passe a fazer parte do direito brasileiro ${ }^{76}$, por mais que os tribunais estejam obrigados a aplicá-la.

Trata-se da diferença entre o que Raz chama de raciocínio sobre o direito [reasoning about law] e de raciocínio de acordo com o direito [reasoning according to law]. O primeiro é governado pela tese das fontes e indicará qual é o conteúdo do direito (qual é a regra aplicada àquela situação), o segundo indicará como deve ser decidido um caso, por exemplo diante de um tribunal, e pode ou não se limitar a identificar o conteúdo do direito. Raciocinar de acordo com o direito será mais do que simplesmente raciocinar sobre o direito nos casos em que uma lei estrangeira ou o conhecimento de outra área (por exemplo, de contabilidade) precisar ser utilizado em uma decisão ou, mais importante, quando considerações morais precisarem ser mobilizadas. ${ }^{77}$ Nesses casos, "o raciocínio jurídico, entendido como o raciocínio de acordo com o direito, envolve muito mais do que estabelecer o que o direito é"78.

Como observa Postema, ao adotarmos a tese das fontes, a teoria do direito passa a ser apenas uma pequena parte do que seria uma teoria daquilo que chamamos de prática jurídica em geral. ${ }^{79-80}$

Voltarei a essa questão dos limites do que se entende por direito no último capítulo desta dissertação. Já é possível adiantar, contudo, que, diferentemente do que Dworkin sugere em várias de suas críticas ao positivismo em geral e a Raz em particular, o que temos aqui não é um argumento linguístico. A separação entre direito e moral não é defendida por

de legalidade estrita, podendo adotar em cada caso a solução que considerar mais conveniente ou oportuna" (art. 723, p.u., Código de Processo Civil, a respeito da sentença em jurisdição voluntária).

${ }^{75}$ Por exemplo, "Para qualificar e reger as obrigações, aplicar-se-á a lei do país em que se constituírem" (art. $9^{\circ}$, Lei de Introdução às Normas do Direito Brasileiro)

${ }^{76} \mathrm{Cf}$. RAZ, Incorporation by Law, p. 10 sobre regras de conexão e também o efeito vinculante de contratos e regulamentos.

${ }^{77}$ RAZ, J. On The Autonomy of Legal Reasoning. In: Ethics in the public domain. Oxford: Clarendon Press, 1995 , p. $332-333$

${ }^{78}$ RAZ, On The Autonomy of Legal Reasoning, p. 333

${ }^{79}$ POSTEMA, A treatise of legal philosophy and general jurisprudence, p. 385

${ }^{80}$ Posteriormente, Raz também inclui "convenções de interpretação" dentro da tese das fontes: "Raz percebe que um conceito tão restritivo não faria jus às nossas experiências. Para expandi-lo, ele tenta englobar aquilo que chama de convenções de interpretação (conventions of interpretation) dentro da tese das fontes sociais. Por convenção de interpretação ele quer dizer um método de interpretar os dispositivos legais, sejam leis ou precedentes, que seja aceito convencionalmente pelos praticantes de direito em um determinado sistema jurídico (RAZ, 2009e [On The Nature of Law, in Between Authority and Interpretation], p. 120-125). Esquematicamente, teríamos uma tese das fontes sociais com o seguinte conteúdo: 'conteúdos explícitos das leis e decisões judiciais + as regras de interpretação aceitas convencionalmente naquela comunidade"" (MURATA, Em Meio à Tempestade..., p. 106). 
Raz com base no sentido comum da palavra "direito". Seu objetivo é encontrar características fundamentais de nossa compreensão da instituição social que é o direito, ${ }^{81}$ por isso ele chama seu empreendimento teórico de "avaliativo" 82 . Ele conclui que entre essas características fundamentais do direito está ser autoritativo e que entre as características fundamentais da autoridade está emitir razões exclusionárias. É dessas conclusões que é retirada a tese das fontes.

\subsection{OBRIGAÇ̃̃O DE OBEDECER AO DIREITO}

Se o direito pretende emitir razões que excluem as razões para a não conformidade isto é, determinam que essas razões sejam desconsideradas na decisão dos cidadãos sobre como agir -, podemos desconfiar que uma obrigação de obedecê-lo colocaria uma exigência muito grande aos cidadãos e que, consequentemente, seria difícil justificar todo esse poder. ${ }^{83}$ Como indicado na Introdução, essas são as conclusões de muitos dos teóricos da obrigação política. Essas também são as conclusões de Raz.

Raz trata de vários argumentos usualmente utilizados para se afirmar a existência de uma obrigação de obedecer ${ }^{84}$, além de fornecer dois argumentos originais (o da "tese da justificação normal" 85 e o do "respeito ao direito" ${ }^{86}$ ). Em todos esses casos conclui, porém,

\footnotetext{
81' This argument for the sources thesis is not an argument from the ordinary sense of 'law' or any other term. It relies on fundamental features of our understanding of a certain social institution, the primary examples of which are contemporary municipal legal systems but which extend beyond them" (RAZ, Legal Positivism and the Sources of Law, p. 50)

${ }^{82}$ RAZ, Authority, Law and Morality, p. 235.

${ }^{83}$ Raz faz uma restrição aos chamados "erros jurisdicionais" (jurisditional mistakes), que seriam erros evidentes e relacionados aos limites da jurisdição de cada autoridade. Nesses casos suas decisões seriam nulas (RAZ, The Morality of Freedom, p. 62). Para um argumento sobre a arbitrariedade dessa restrição, cf. MURATA, Em Meio à Tempestade..., p. 129.

${ }^{84} \mathrm{O}$ argumento do consentimento (RAZ, J. The Obligation to Obey the Law. In:

The Authority of Law: Essays on Law and Morality. 2nd Edition. ed. Oxford: Clarendon Press, 2009, p. 238-239), o argumento do "mau exemplo" (ibid., p. 237-238), o argumento do dever de manter boas instituições (ibid., p. 241) e o argumento da democracia (ibid., p. 241), além do argumento de razões prudenciais (ibid., p. 244)

85 “[...] the normal way to establish that a person has authority over another person involves showing that the alleged subject is likely better to comply with reasons which apply to him (other than the alleged authoritative directives) if he accepts the directives of the alleged authority as authoritatively binding and tries to follow them rather than by trying to follow the reasons which apply to him directly."(RAZ, The Morality of Freedom, p. 53)

86 "A person who respects the law expresses in this way his attitude to society, his identification with and loyalty to it. Such a person may find it appropriate to express these attitudes to society, among other ways, through his attitude to the law. [...] In any case, for the person who respects the law there is an obligation to obey. His respect is the source of this obligation" (RAZ, Legal Reasons, Sources, and Gaps, p. 260)
} 
ou que o argumento é insuficiente para fazer surgir uma obrigação de obedecer para qualquer pessoa ou que é suficiente para obrigar apenas alguns cidadãos. ${ }^{87}$

O importante a destacar aqui é que Raz procede da mesma forma que os teóricos da obrigação política a que me referi na Seção 1.2 acima. Identificado, em primeiro lugar, o direito - no caso de Raz, através de sua tese das fontes -, ele procura, em segundo lugar, responder se há uma obrigação de obedecê-lo. Ou seja, a relação do direito com o conceito de autoridade e a relação do conceito de autoridade com a emissão de razão exclusionárias não têm nada de engajadas. São descrições, que não significam que o direito seja justificado, nem mesmo significam que alguma autoridade possa ser legítima.

Depois de descrito o direito dessa forma, outra questão será se ele tem legitimidade e pode gerar uma obrigação de obedecer aos cidadãos, isto é, se as razões que ele emite e reivindica que sejam exclusionárias devem ser, de fato, assim consideradas. ${ }^{88}$ Nesse momento, e apenas a partir desse momento, Raz já não pretende mais estar descrevendo o que o direito é, mas se engajando em um argumento moral ${ }^{89}$.

\subsection{O QUE PODE SER UMA TEORIA DO DIREITO?}

Está bem clara em Raz, portanto, a distinção entre descrever e justificar. Ele não é um cético moral e admite que podem existir argumentos para justificar a autoridade de um Estado, desenvolvendo sua própria teoria sobre que argumentos poderiam ser esses - a tese da justificação normal e o argumento sobre o respeito ao direito. A tese da justificação

\footnotetext{
${ }^{87}$ Isso não significa, porém, que exista um direito à desobediência civil, que, como é pública, pode trazer consequências negativas que podem torná-la moralmente errada (RAZ, J. A Right to Dissent? I. Civil Disobedience. In: _ The Authority of Law: Essays on Law and Morality. 2nd Edition. ed. Oxford: Clarendon Press, 2009), nem um direito à objeção de consciência, já que o objetor pode achar que não tem um dever quando, na verdade, ele o tem (RAZ, J. A Right to Dissent? II. Conscientious Objection. In: The Authority of Law: Essays on Law and Morality. 2nd Edition. ed. Oxford: Clarendon Press, 2009, p. 277). Ou seja, não é porque não há um dever de obedecer ao direito por ser direito que todas as exigências feitas pelo Estado serão moralmente injustificadas.

${ }^{88}$ Como resume Rubens Glezer: "[...] a Tese das Fontes Sociais não é um argumento sobre a obrigatoriedade das diretrizes jurídicas e nem quais são as condições para que regras jurídicas sejam reconhecidas como efetivas razões para a ação. Ao contrário, para Raz, a eventual normatividade do direito existe apenas se forem preenchidas certas exigências morais bastante demandantes: regras jurídicas somente são 'normas' (obrigatórias) se existir uma relação de autoridade legítima entre o sujeito e o Estado." (GLEZER, R. E. O Positivismo de Joseph Raz: Autoridade e Razão Prática sem Prática Social. São Paulo: Universidade de São Paulo - Tese de Doutorado, 2014, p. 12)

${ }^{89}$ Como o próprio Raz esclarece, a tese da justificação normal é "a moral thesis about the type of argument which could be used to establish the legitimacy of authority' (RAZ, Authority and Justification, Philosophy \& Public Affairs, 14/1 (winter 1985), p. 18).
} 
normal e o argumento sobre o respeito ao direito são, porém, parte da teoria política de Raz, que nada tem a ver com a forma como ele constrói sua teoria do direito.

A identificação de o que é o direito, feita pela teoria do direito, é empreendimento completamente diverso dessa investigação sobre legitimidade e é feita pela tese das fontes. Raz entende que a teoria do direito é fundamentalmente "uma investigação sobre a natureza do direito e as características fundamentais das instituições e práticas jurídicas" ${ }^{90}$. Como pode ser feita essa investigação?

Sendo uma investigação filosófica, ela pressupõe que existam pessoas que usam o conceito de direito de forma competente e pretende "melhorar a compreensão que elas têm do conceito" 91 , dando uma "compreensão mais sistemática" sobre ele ${ }^{92}$. Como ressalvado por Raz em relação às explicações de conceitos em geral, isso não significa que tenham que ser identificadas todas as condições necessárias e suficientes para a aplicação do conceito de direito. A análise conceitual também se ocupa da conexão de um conceito com outros conceitos; "explicamos conceitos em parte ao localizá-los dentro de uma rede conceitual"93.

A pergunta sobre o que o direito é buscará, então, suas características fundamentais, inclusive relacionando-o com outros conceitos. Como visto, isso é feito por Raz, primeiramente, destacando a centralidade do conceito de autoridade dentre essas características; partimos, depois, à pergunta sobre o que a autoridade tem de essencial, o que, por sua vez, é explicado através das categorias "razões de primeira ordem" e "razões de segunda ordem" e, mais especificamente, "razões exclusionárias" e "razões protegidas".

Feito tudo isso, podemos concluir que a identificação do direito - isto é, a identificação de quais proposições jurídicas são verdadeiras e quais não são - deve ser independente de considerações morais, o que nos leva à tese das fontes. O uso do verbo “dever” aqui não indica nenhum imperativo moral, mas um esclarecimento conceitual. Levar em consideração razões morais para identificar o direito é se confundir.

\footnotetext{
${ }^{90}$ RAZ, J. Two Views of the Nature of the Theory of Law: A Partial Comparison. In: RAZ, J. Between Authority and Interpretation - On the Theory of Law and Practical Reason. Oxford: Oxford University Press, 2009, p. 49.

${ }^{91}$ Essa seria a diferença entre uma explicação filosófica e uma explicação "comum”, já que esta última "pode objetivar tornar as pessoas usuárias competentes do conceito" (Raz, Two Views of the Nature of the Theory of Law, p. 55-56).

92 RAZ, Two Views of the Nature of the Theory of Law, p.71

${ }^{93}$ RAZ, Two Views of the Nature of the Theory of Law, p. 56-57.
} 
Para Raz, o que uma teoria do direito pode nos oferecer, portanto, é clareza sobre como um conceito importante funciona e sobre as práticas e instituições a que esse conceito se refere. Clareza sobre como identificar o que é direito e o que não é, empreendimento relevante já que o direito é "um tipo de instituição humana de importância decisiva na regulação da vida social"94, "reivindica oferecer a estrutura geral para a conduta de todos os aspectos da vida social e se coloca como o supremo guardião da sociedade" 95 ao mesmo tempo em que é "suficientemente diferente de outros sistemas normativos para merecer ser estudado separadamente" 96 .

O objetivo é esclarecer que tipo de reivindicação o direito faz, que tipo de obrigações ele pretende impor e como isso se relaciona a outros âmbitos do nosso raciocínio prático ${ }^{97}$ como o direito pode, por meio da emissão de razões exclusionárias modificar a moralidade, entendida como o conjunto de razões que temos para agir ${ }^{98}$. Nas palavras de Raz, a tarefa da teoria do direito seria "melhorar nossa compreensão da sociedade ajudando-nos a compreender como as pessoas compreendem a si próprias" ${ }^{" 99}$. A teoria do direito será tão mais competente quanto mais se conformar às regras que orientam a utilização do conceito de direito que ela pretende explicar.

A tarefa do teórico seria tão neutra que Raz afirma que apenas uma má teoria poderia levar a alguma mudança prática. À medida em que as conclusões dessa má teoria, que pretendem ser descritivas mas não são, fossem aceitas por quem participa da prática, a prática se modificaria tornando verdadeira a teoria que era inicialmente falsa. ${ }^{100}$ Uma boa teoria, por outro lado, apenas explicará. A teoria de Raz pretende explicar o conceito como ele é, o conceito que "as pessoas usam para entender características de suas próprias vidas e do mundo ao seu redor" ${ }^{101}$. Pode haver nisso algo de avaliativo - o teórico precisará

\footnotetext{
${ }^{94}$ RAZ, Legal Positivism and the Sources of Law, p. 52.

${ }^{95}$ RAZ, The Institutional Nature of Law, p. 121

${ }^{96}$ RAZ, The Institutional Nature of Law, p. 105

97 “Mesmo um positivista como Raz está hoje preocupado com as razões jurídicas que podemos ter e com as diferenças específicas das razões jurídicas para agir. Ele não cai, porém, na mesma linha dos positivistas que o antecederam e cuja preocupação era com as normas em si: seu objeto de reflexão diz respeito ao processo decisório.” (LOPES, J. R. D. L. Filosofia analítica e hermenêutica: Preliminares a uma teoria do direito como prática. Revista de Informação Legislativa, Brasília, n. 212, p. 203-226, out/dez 2016, p. 215)

${ }_{98}$ Esta questão está claramente colocada nesses termos em RAZ, Incorporation by Law.

${ }^{99}$ No original: "to advance our understanding of society by helping us understand how people understand themselves" (RAZ, Authority, Law and Morality, 237)

${ }^{100}$ RAZ, On The Nature of Law, p. 98-99.

${ }^{101}$ RAZ, Two Views of the Nature of the Theory of Law, p.75
} 
identificar o que é mais importante ao explicar o conceito de direito ${ }^{102}$ - mas não há nada de moral ${ }^{103}$. A clareza que o teórico pode trazer ao oferecer uma teoria descritiva não depende de que ofereça, também, uma justificativa da prática que ele descreve.

Como veremos, isso será criticado por Dworkin, que dirá que a descrição pretendida por Raz é malsucedida e que, mais do que descrever, uma teoria do direito deve se preocupar em nos dizer como agir ${ }^{104}$. De fato, a teoria de Raz não diz respeito a como os tribunais decidem ou devem decidir. Como já destaquei, Raz afirma que sua teoria não se confunde com uma teoria da adjudicação e que muito do que os tribunais fazem não é - e nem deve ser - aplicar o direito. O raciocínio jurídico é uma espécie de raciocínio moral e "teses jurídicas [legal doctrines] são justificadas apenas se forem moralmente justificadas e devem ser seguidas apenas se for moralmente correto segui-las"105. Decidir casos, assim como decidir como agir em qualquer situação, é um empreendimento moral ${ }^{106}$, mas teorizar sobre a natureza do direito não é.

\subsection{UM ABISMO ENTRE O QUE O DIREITO EXIGE E O QUE PODE SER JUSTIFICADO}

Como já adiantei, não entrarei na discussão sobre se a tese da justificação normal e o respeito ao direito são suficientes para estabelecer uma obrigação de obedecer ao direito e em qual extensão. Apresentando o argumento de Raz, pretendo, porém, ter mostrado como é possível a construção de um conceito de direito independentemente de referências à sua justificação.

Raz procura descrever a natureza da instituição social que é o direito; em um esforço analítico, pretende esclarecer como essa instituição funciona e como afeta nossa razão

\footnotetext{
102 “[...][ao] afirmar que tais características são importantes, não se está elogiando-as como boas [...] Tudo que é afirmado é a centralidade em nossa experiência social das instituições que expressam o que afirmam ser o julgamento coletivo e vinculante de sua sociedade sobre como as pessoas devem se comportar" (RAZ, Authority, Law and Morality, p. 236)

${ }^{103}$ Waluchow lê Raz nesse ponto como afirmando que seria possível que a teoria destacasse alguns elementos da prática porque eles são moralmente relevantes, sem que isso comprometesse o teórico a dizer que a prática é moralmente justificada (WALUCHOW, Inclusive Legal Positivism, p. 22). Ainda assim, a atividade do teórico será desengajada.

${ }^{104}$ DWORKIN, The Concepts of Law, p. 229

${ }^{105}$ RAZ, Ethics in the Public Domain, p. 340

${ }^{106}$ A moralidade se aplica a todos nós simplesmente por ser compostas por razões, entendidas como considerações que devem guiar o comportamento de agentes. Mesmo que seu papel institucional dê a eles algumas razões específicas, os juízes são pessoas e, simplesmente por isso, estão sujeitos à moralidade (RAZ, Incorporation by Law, p. 2-3). Voltarei a este ponto no Capítulo 5.
} 
prática - ou, em outras palavras, como o direito pode modificar a moralidade. Por isso, entendo que é incorreto classificar o empreendimento raziano de linguístico (ou “semântico"). ${ }^{107}$ A afirmação de que o direito reivindica autoridade e que essa reivindicação significa que suas diretivas devem ser compreendidas como razões exclusionárias não é uma afirmação sobre o sentido da palavra "direito". Raz pretende, de fato, estar esclarecendo o que é o direito como aspecto fundamental da nossa realidade social. ${ }^{108}$

Dworkin afirma que Raz não é bem-sucedido nessa tarefa descritiva. Para ele, a concepção raziana de autoridade pressuporia "um nível de deferência em relação à autoridade jurídica que quase ninguém demonstra em democracias modernas". Dworkin argumenta que nós não tratamos nem leis que consideramos boas como excludentes das razões a elas subjacentes. Essas razões subjacentes (“dependentes”, diria Raz) mantêm-se válidas e algumas vezes precisamos recorrer a elas para decidir se vamos seguir o direito ${ }^{109}$. Para ele, o fato de que a interpretação de uma regra dependa de considerações morais não impede que ela seja considerada autoritativa. ${ }^{110}$ A mesma crítica é feita por outros teóricos em relação à concepção de Raz de autoridade em geral, negando que o conceito de autoridade precise ser relacionado com o conceito de "razões exclusionárias" 111 ou mesmo negando que faça sentido falar em razões desse tipo. ${ }^{12} \mathrm{O}$ que se pode argumentar contra isso?

Um argumento empírico teria alguma força aqui. Um instituto de pesquisa poderia, a partir de uma amostra da população de um país, procurar definir como essa população vê o direito, se de fato o vê como reivindicando o nível de deferência que Raz descreve. Mas esse não seria um argumento definitivo. Embora o argumento de Raz seja descritivo, ele não é descritivo das atitudes das pessoas, mas da instituição de que elas participam. Não podemos descartar, assim, que as pessoas estejam simplesmente erradas sobre a forma como encaram o direito e sua autoridade. A abordagem de Raz pretende "ajudar a explicar em que

\footnotetext{
${ }^{107}$ Como as primeiras formulações do argumento de Dworkin sobre o "ferrão semântico" pareciam sugerir (cf. DWORKIN, Law's Empire, p. 45-46).

${ }_{108}$ RAZ, Authority, Law and Morality, p. 237.

${ }^{109}$ DWORKIN, R. Thirty years on. In: p. 206

Justice in Robes. Cambridge: Harvard University Press, 2006,

110 DWORKIN, R. Introduction: Law and Morals. In:

Justice in Robes. Cambridge: Harvard University Press, 2006, p. 33; a mesma crítica é feita por Will Waluchow (WALUCHOW, Inclusive Legal Positivism, p. 129-140)

${ }^{111} \mathrm{Um}$ resumo desses argumentos é oferecido em POSTEMA, A treatise of legal philosophy and general jurisprudence, p. 370-372.

${ }_{112}$ Para um argumento nesse sentido, ver MURATA, Em Meio à Tempestade..., p. 79-114.
} 
as pessoas acreditam quando elas acreditam que uma pessoa tem autoridade", essa abordagem destaca características importantes do que as pessoas entendem por autoridade, mas ela "não necessariamente se conforma em todos os detalhes à noção de autoridade de todas as pessoas" $" 113$.

Como visto, a teoria do direito defendida por Raz nos leva a exigências tão altas de conformidade por parte dos cidadãos que o próprio Raz não consegue fundamentar que os estados contemporâneos estejam, de fato, justificados em exigir o que sua teoria afirma que eles exigem. Isto é, as reivindicações que o direito faria de que as razões que ele emite são excludentes das razões em sentido contrário são não apenas ocasionalmente falsas, mas sistematicamente e quase sempre falsas ${ }^{114}$.

Penso que a questão é, então, se nossa prática jurídica é assim tão restrita a ponto de não admitir que se defenda que o direito deve (isto é, que temos razões morais substantivas para entender que ele deva) ser entendido como algo diferente de ordens de uma autoridade com a força exclusionária afirmada por Raz.

O fato de que a teoria do direito de Raz nos leva a esse abismo entre o que o direito exige e o que pode ser moralmente justificado permite que a abandonemos em favor de outra teoria que não nos leve a essa situação? Nos próximos dois capítulos, responderei a essa pergunta positivamente e defenderei que a teoria de Dworkin pode cumprir esse papel. 


\section{TEORIA do DIREITO COMO JUSTIFICAÇÃo: A ABORDAGEM DE RONALD DWORKIN}

Um professor diz a seus alunos que o prazo para a interposição de um recurso de apelação é de 15 dias (art. 1.003, §5 , Código de Processo Civil). O Supremo Tribunal Federal decide que a imunidade tributária prevista para livros também se aplica a e-books (RE 330817). O Superior Tribunal de Justiça afirma que pode ser concedida justiça gratuita a estrangeiros não residentes no Brasil (REsp 1225854). Esses são exemplos aleatórios de afirmações sobre o que o direito brasileiro é. São proposições em que está em questão o que Dworkin chama de conceito doutrinal de direito, o conceito que utilizamos quando perguntamos o que o direito permite, exige ou proíbe ${ }^{115}$.

A categoria "conceito doutrinal"116 diferencia esse tipo de situação daquelas em que estamos empregando o conceito de direito em um sentido aspiracional ou em um sentido sociológico. O conceito aspiracional é utilizado para nos referirmos ao ideal de legalidade ou ao ideal do Estado de Direito (rule of law) como um ideal de moralidade política. ${ }^{117} \mathrm{O}$ conceito sociológico é utilizado para denominar determinada estrutura social para algum fim particular, como facilitar um projeto de pesquisa, descrever a estrutura de alguma sociedade antiga, demonstrar alguma correlação, etc. Nesses casos, não há nada de errado em utilizarmos um sentido estipulativo de direito. Por outro lado, também não há nada que permita a conclusão de que essa definição estipulativa tenha descoberto a "essência" de alguma coisa. ${ }^{118}$ Um outro conceito de direito seria, ainda, o "taxonômico", utilizado por teóricos do direito que supõem que qualquer comunidade política que tem direito em um sentido sociológico tem também um conjunto de regras e padrões individualizados que são

\footnotetext{
${ }^{115}$ DWORKIN, Introduction: Law and Morals, p. 2.

116 Traduzo "doctrinal" pelo neologismo "doutrinal" ao invés de "doutrinário" para evitar confusões com o que se entende por "doutrina" no Brasil: "[n]um certo sentido, pode-se afirmar que muitas vezes o conceito dogmático de direito, apresentado nos livros de 'doutrina jurídica', mais se aproxima do conceito sociológico, definido por Dworkin, na medida em que acolhe o princípio da legalidade e o fato da positivação como o ponto de partida dogmático como sua concepção do direito" (MACEDO Jr, Do Xadrez à Cortesia: Dworkin e a Teoria do Direito Contemporânea, p. 182). Ressalvo que se tomássemos doutrina simplesmente como "teorias visam mostrar o que é "requerido, proibido, permitido ou criado"” (REIS, L. S. Direito e Método: a contribuição de Ronald Dworkin. São Paulo: Dissertação de Mestrado - Departamento de Filosofia e Teoria Geral do Direito USP, 2013, p. 100), então a tradução por “doutrinário" também seria adequada. A escolha de "doutrinal” visa apenas evitar possíveis ambiguidades.

${ }^{117}$ DWORKIN, Introduction: Law and Morals, p. 5.

${ }^{118}$ DWORKIN, Introduction: Law and Morals, p. 2-3.
} 
jurídicos em oposição a padrões morais, costumeiros ou de outros tipos. Este último conceito seria para Dworkin, entretanto, uma "ficção escolástica"119 , por motivos que ainda abordarei.

Tais categorias servem para deixar mais claro do que estão tratando as teorias do direito. É do conceito doutrinal de direito que estamos nos ocupando ao construir uma teoria do direito que permita dizer o que o direito permite, exige ou proíbe em casos concretos. ${ }^{120}$ A teoria dará, então, os critérios para dizermos se proposições jurídicas do tipo "o direito brasileiro permite $\mathrm{x}$ " e "o direito brasileiro proíbe y" são corretas ou incorretas. Em outras palavras, responderá o que faz com que seja verdade que, por exemplo, o prazo para interposição de um recurso de apelação seja de 15 dias, e-books tenham direito a imunidade e estrangeiros não residentes tenham direito à justiça gratuita.

Com a afirmação de que a teoria do direito oferece os critérios para identificar $o$ que o direito é um positivista como Raz pode concordar. Dworkin não diz, porém, apenas que uma teoria do direito oferece critério para dizer o que o direito é. Ele afirma que o direito é o "esquema de direitos e responsabilidades que permitem a coerção porque decorrem de [flow from] decisões passadas do tipo adequado" 121 e que, considerando esse conceito, as diferentes teorias - ou concepções - sobre o conceito doutrinal de direito pretendem responder às seguintes questões: “A conexão entre direito e coerção é justificada? Existe algum propósito [point] em exigirmos que haja coerção apenas de acordo com o direito?", "Se existe esse propósito [point], qual é ele?"

“Que sentido de "decorrem" melhor serve a esse propósito [point]?”. ${ }^{122}$

Ainda voltarei a essa distinção entre conceitos e concepções. O importante, agora, é perceber que Dworkin está propondo que as diferentes teorias do direito se baseiam, cada uma, em diferentes formas de justificar a coerção estatal ${ }^{123}$, oferecendo uma resposta tanto

\footnotetext{
${ }^{119}$ DWORKIN, Introduction: Law and Morals, p. 4.

${ }^{120}$ DWORKIN, R. Justice for Hedgehogs. Cambridge: Belknap Press, 2011, p. 402

${ }^{121}$ No original: "Law is the scheme of rights and responsibilities that license coercion because they flow from past decisions of the right sort." (DWORKIN, Law’s Empire, p. 93)

122 DWORKIN, Law's Empire, p. 94

${ }^{123}$ Em texto mais recente, Dworkin chegou mesmo a propor que a centralidade da justificação da coerção aplica-se não só aos direitos nacionais, mas também ao direito internacional, na relação entre países: "However, the modern question — what justifies coercive political power? - arises not just within each of the sovereign states who are members of the Westphalian system but also about the system itself: that is, about each state's decision to respect the principles of that system. For those principles are not independent of but are actually
} 
sobre qual é o sentido [point] dessa justificação pelo direito quanto sobre como esse sentido pode ser melhor servido.

Mas é disso mesmo que tratam as diferentes teorias do direito? A afirmação do conceito de direito como justificação da coerção não é incontroversa entre elas. Ao contrário, as teorias do direito - mesmo as teorias do conceito doutrinal de direito - geralmente não são feitas nessas bases. Raz, por exemplo, não parte expressamente desse conceito que liga o direito à justificação da coerção ${ }^{124} \mathrm{e}$, mesmo assim, constrói, como visto, toda uma teoria sobre como o direito deve ser compreendido e, através de sua tese das fontes, podemos dizer, sobre como a veracidade das proposições jurídicas deve ser verificada. Ao contrário do que sugere o conceito de direito proposto por Dworkin, essa compreensão e essa verificação devem ser feitas, para Raz, independentemente de qualquer análise de justificação.

Que argumentos poderíamos ter para afirmar que esse ponto de partida de Dworkin, esse conceito de direito, é o correto? Por que dizer que o direito é o "esquema de direitos e responsabilidades que permitem a coerção" e que as teorias do direito se distinguem pela forma como justificam essa coerção?

\subsection{TEORIAS SOBRE OS FUNDAMENTOS DO DIREITO}

Para responder por que deveríamos aceitar o conceito de direito proposto por Dworkin, podemos nos perguntar, antes, o que poderia ser uma concepção de direito (e uma teoria do direito) não relacionada à justificação da coerção. A distinção que Dworkin faz entre fundamentos do direito (grounds of law) e força do direito (force of law) é útil para pensarmos essa possibilidade e, também, para percebermos como a teoria do direito de Raz, sua tese das fontes, pretende se ocupar apenas dos fundamentos do direito e, não se preocupando com sua força (assunto de sua filosofia política), assume um caráter "taxonômico" e perde muito de sua relevância.

Os fundamentos do direito (grounds of law) são os padrões de correção das proposições jurídicas, sendo as proposições jurídicas “todas as várias afirmações e

part of the coercive system each of those states imposes on its citizens." (DWORKIN, R. A New Philosophy for International Law. Philosophy and Public Affairs, v. 41, n. 1, 2013, p. 16-17)

${ }^{124}$ O próprio Dworkin cita Raz como exemplo de teórico cuja teoria não parte dessa definição (DWORKIN, Law's Empire, p. 429). 
reivindicações que as pessoas fazem sobre o que o direito permite, proíbe ou lhes dá o direito de ter"125; por exemplo, é possível dizer que o fundamento para a proposição jurídica de que é crime matar é a existência do tipo penal de homicídio no Código Penal (art. 121, CP), lei federal que observa a competência privativa da União para legislar sobre direito penal (art. 22, I, CF). A força do direito (force of law), por sua vez, é o poder de qualquer proposição jurídica de justificar a coerção ${ }^{126}$; por exemplo, a justificação para que o estado imponha a pena de prisão ao homicida.

Falar em "poder" e "força" pode dar a impressão de que se está tratando de um poder de fato, que poderia ser descrito por algum observador que percebesse, por exemplo, que no Brasil existem cerca de 80 mil pessoas presas por homicídio ${ }^{127}$. Mas a força do direito de que Dworkin está tratando diz respeito à justificação. Isto é, seguindo no exemplo, diz respeito a saber se é correto que o estado prenda essas pessoas, se ele tem um direito de fazêlo.

O que faria, então, uma teoria que não se pergunta sobre a capacidade do direito de justificar a coerção? Ela se ocuparia apenas de buscar os fundamentos das proposições jurídicas, distinguindo o que é jurídico e o que não é. Estaria preocupada com uma taxonomia de normas e, eventualmente, com buscar relações entre essas normas. Nada nessa busca nos leva a dizer que identificamos, ao identificar o direito, também as obrigações dos juízes ou de qualquer outra pessoa. A pergunta sobre quais são os critérios para identificar o direito não é a pergunta sobre quais são os critérios para identificar um argumento que deva ser utilizado por um juiz. Os juízes muitas vezes terão que aplicar padrões que não são jurídicos (padrões morais, regras de outras jurisdições, regras de domínios específicos do conhecimento, como matemática e contabilidade, etc.) e, para eles, identificar quais padrões eles devem aplicar porque são direito e quais padrões não jurídicos eles devem aplicar por outras razões geralmente não traz nenhuma diferença prática. ${ }^{128}$ Mesmo assim, uma teoria sobre os fundamentos do direito buscará identificar o que é um padrão jurídico e o que não é.

\footnotetext{
${ }^{125}$ DWORKIN, Law's Empire, p. 4

${ }^{126}$ DWORKIN, Law's Empire, p. 110.

127 http://agenciabrasil.ebc.com.br/geral/noticia/2017-12/populacao-carceraria-do-brasil-sobe-de-622202para-726712-pessoas

${ }^{128}$ RAZ, Incorporation by Law, p. 15
} 
A tese das fontes, por exemplo, identifica o direito com uma ideia de autoridade, entendida como capacidade de emitir razões exclusionárias e, com isso, dá os critérios (os fundamentos do direito) para que possamos identificar quais proposições jurídicas são verdadeiras. São jurídicas aquelas proposições que se baseiam apenas em fatos reconhecidos como fontes de direito naquele sistema jurídico em particular - por exemplo, proposições respaldadas pelo ato de promulgação de uma lei.

No caso do crime de homicídio, uma teoria sobre os fundamentos do direito poderia nos dizer que faz parte do direito brasileiro uma proibição ao homicídio, apontando como fundamento o fato de ter sido promulgado o Código Penal, que traz essa regra, e a observância na edição dessa lei das regras de competência fixadas na Constituição Federal. Mas daí não se seguiria nenhuma justificativa para agir de uma forma ou de outra. A pergunta sobre o Estado estar ou não justificado a prender seria posterior e "externa" à teoria e, diferentemente dela, dependente de argumentos substantivos de moralidade política.

Essa separação entre a análise dos fundamentos e da força do direito também afeta a forma como as teorias da obrigação política, vistas na Seção 1.2 da Introdução, são construídas, inclusive a própria tese da justificação normal de Raz. Tais teorias se ocuparão apenas da força do direito, presumindo a ausência de controvérsia - ou pelo menos a ausência de controvérsias reportáveis a divergências de moralidade política - sobre seus fundamentos, estes objeto da teoria do direito. ${ }^{129}$

\subsubsection{VALIDADE E CONTEÚDO DO DIREITO}

Uma outra forma de explicar o que faz uma teoria ocupada com os fundamentos do direito, em oposição a uma teoria ocupada com a força do direito, é destacar sua relação com o conceito de validade ${ }^{130}$. Essa categoria, geralmente apresentada ao estudante de Direito no

\footnotetext{
${ }^{129}$ Nesse sentido, estendo a conclusão também para as teorias sobre desobediência civil, DWORKIN, Law’s Empire, p. 112-113.

${ }^{130}$ Em The Place of Legitimacy in Jurisprudence, Dan Priel utiliza quatro conceitos para tentar mostrar o erro dos positivistas na leitura que eles fazem da teoria do direito de Dworkin. Trata-se dos conceitos de validade das normas jurídicas, conteúdo das normas jurídicas, normatividade do direito e legitimidade do direito (p. 6). Tratarei, aqui, da relação entre validade e conteúdo e, mais a frente (na subseção 3.1.2.2), da relação entre legitimidade e conteúdo.
} 
início de sua graduação, corresponde ao pertencimento a um sistema jurídico. Como explica Tércio Sampaio Ferraz Jr, no que chama de "ponto de vista dogmático":

Validade é uma qualidade da norma que designa sua pertinência ao ordenamento, por terem sido obedecidas as condições formais e materiais de sua produção e consequente integração no sistema. ${ }^{131}$

Raz faz algumas qualificações à definição de validade como pertencimento a um sistema jurídico. Ele argumenta que existem normas que não pertencem a um dado sistema jurídico e que, ainda assim, são válidas perante esse sistema - como normas jurídicas estrangeiras, mediante regras de conexão. Melhor seria, por isso, definir válido como "legalmente vinculante", o que significa que "uma regra válida é uma regra que tem efeitos jurídicos". ${ }^{132}$ De forma aparentemente surpreendente, Raz afirma que dizer que uma norma é válida é dizer que "ela tem as consequências normativas que ela pretende ter" ${ }^{33}$, o que significa que "se uma regra jurídica pretende impor uma obrigação a X, então X está sob essa obrigação porque essa regra é uma regra jurídica"134. Isso pode parecer inconsistente com a ambição descritiva da teoria de Raz, por deduzir da validade de uma regra uma obrigação, mas logo ele ressalva que se trata de afirmações desengajadas, feitas "a partir de um ponto de vista relevante", que não implicam a aceitação dessas consequências normativas, isto é, não implicam a aceitação da legitimidade do direito e de sua capacidade de efetivamente impor obrigações, mas apenas descrevem um ponto de vista jurídico, explicando quais os deveres e os direitos que as pessoas teriam de acordo com o direito. ${ }^{135}$

Assim, mesmo com esse aparente desvio, a tese das fontes de Raz ainda pode ser vista como uma teoria sobre condições de validade de normas jurídicas, no sentido em que tradicionalmente este conceito é utilizado. Como aponta Waluchow, Raz iguala a existência de uma regra jurídica com sua validade: "Se uma regra jurídica existe então ela é válida e se ela é válida então ela existe. [...] Não há leis inválidas de acordo com Raz" ${ }^{136}$, o que

\footnotetext{
${ }^{131}$ FERRAZ JUNIOR, T. S. Introdução ao estudo do direito: técnica, decisão, dominação. $4^{\mathrm{a}}$ edição. ed. São Paulo: Atlas, 2003, p. 203

${ }^{132}$ RAZ, Legal Validity, p. 148-149

${ }^{133}$ RAZ, Legal Validity, p. 150

${ }^{134}$ RAZ, Legal Validity, p. 149

${ }^{135}$ RAZ, Legal Validity, p. 153-157

${ }^{136}$ WALUCHOW, Inclusive Legal Positivism, p. 82
} 
corresponde justamente ao que é feito por uma explicação como a de Ferraz Jr. reproduzida acima. $^{137}$

Mais especificamente, a tese das fontes dirá que são válidas as normas derivadas de ordens emitidas por instituições competentes, atendidas as exigências de que alguns fatos tenham acontecido. No caso brasileiro, as leis devem ter sido propostas pela autoridade competente - observadas, por exemplo, as regras de iniciativa privativa do Presidente da República (art. 61, $\S 1^{\circ}, \mathrm{CF}$ ) - devem ter passado por votação nas casas do Congresso Nacional (art. 65, CF) e devem ser sancionadas pelo Presidente da República (art. 66, CF). As divergências sobre a validade de uma norma dirão respeito, então, estritamente a fatos como esses, serão desacordos empíricos ${ }^{138}$ :

Já que a validade de uma lei depende de sua fonte e já que a fonte é uma ação ou uma série de ações, dúvidas e discussões sobre a validade de leis giram em torno de questões factuais, de assuntos suscetíveis de determinação objetiva para os quais as visões morais ou políticas de alguém são essencialmente irrelevantes. ${ }^{139}$

Trata-se de uma teoria que procura diferenciar uma norma jurídica de outra espécie de norma (social, moral, de um jogo, etc.) pensando o direito como um conjunto determinado de normas que passam por testes de validade e, por isso, são jurídicas - um conceito taxonômico de direito. Atendidos os requisitos para que uma norma seja válida - cumpridas as condições colocadas pelos fundamentos do direito - o conteúdo dessas normas, isto é, o que cada norma prescreve, proíbe, etc., será facilmente identificável. A partir desse conteúdo, por sua vez, será aferido se o direito tem ou não legitimidade, podendo ou não gerar uma obrigação de obedecer.

\subsection{DIREITO COMO JUSTIFICAÇÃO DA COERÇÃO}

\footnotetext{
${ }^{137}$ Existe também um uso comum do conceito de "validade" no Brasil em relação a atos jurídicos, sobretudo no direito civil, que é atribuído a Pontes de Miranda e distingue validade de existência e de eficácia (para uma apresentação do que seriam esses três "planos", cf. MELLO, M. B. D. Teoria do Fato Jurídico - Plano da Existência. 16 Edição. ed. São Paulo: Saraiva, 2010, p. 101-108). Ressalvo que não estou tratando de validade nesse sentido.

${ }^{138}$ Dworkin diferencia "desacordos empíricos", sobre fatos (como ter ou não uma norma sido promulgada em determinada data) de "desacordos teóricos", sobre quais são os fundamentos do direito. (DWORKIN, Law's Empire, p. 4-6).

${ }^{139}$ RAZ, Legal Validity, p. 152
} 
Proposições do tipo "de acordo com o direito brasileiro, é permitido/proibido x" costumam ser acompanhadas de consequências práticas sobre a vida das pessoas. Muitas vezes, consequências extremas, com utilização de violência. É uma característica das diversas instituições que chamamos de "direito" que suas normas são respaldadas pela ameaça do uso da força ${ }^{140}$. A prisão de alguém, a cobrança de um imposto (que pode resultar em uma expropriação) e o oferecimento de um serviço público (que coloca obrigações para quem está incumbido de prestá-lo, cujo descumprimento também pode levar ao uso de meios coercitivos) são exemplos de práticas respaldadas por uma ameaça de uso da força e fundamentadas em proposições que utilizam o conceito doutrinal de direito.

Como afirma Kenneth Himma,

Uma das características mais evidentes do direito [...] em todo sistema jurídico existente de que temos conhecimento, é que ele autoriza a utilização de mecanismos coercitivos para algumas violações do direito. O caráter coercitivo do direito, como o conhecemos de nossa experiência, não é menos evidente do que o fato de que os direitos consistem de normas e de que os sistemas jurídicos têm órgãos que produzem normas. A autorização para a utilização de mecanismos coercitivos é absolutamente onipresente entre os sistemas jurídicos que existem em nosso mundo. Isso é incontroverso e não suscita nenhuma questão conceitual; é um fato empírico. ${ }^{141}$

Uma primeira pergunta que a afirmação da centralidade da coerção no direito pode colocar é se ela não é exagerada. A ameaça e a utilização de violência têm realmente um papel tão importante na prática jurídica? Quando pensamos, por exemplo, no regime jurídico dos contratos ou em uma área como o direito societário, a coerção ainda teria essa importância? Essa questão é colocada por Leslie Green, para quem a centralidade que Dworkin dá à coerção

mostra uma tendência kelseniana que frequentemente se expressa no pensamento de Dworkin. Nessa visão, o propósito [point] do direito não é governar as relações interpessoais diretamente, impondo deveres e colocando padrões de comportamento, ele é governá-las indiretamente instruindo as autoridades sobre quando usar ou se abster de usar a força. É plausível ou distorce o sentido, por exemplo, da responsabilidade civil [tort] ou dos contratos, vê-los como primordialmente guiando e

\footnotetext{
${ }^{140}$ Keneth Himma chega a dizer que a autorização para o uso de mecanismos de imposição coercitiva [coercive enforcement mechanisms] é uma "característica conceitualmente necessária do direito" (HIMMA, K. The Authorization of Coercive Enforcement Mechanisms as a Conceptually Necessary Feature of Law. https://papers.ssrn.com/sol3/papers.cfm?abstract_id=2660468, Setembro 2015, p. 1).

${ }^{141}$ HIMMA, The Authorization of Coercive..., p. 11
} 
constrangendo governos em seu uso da força? Nossas discussões sobre essas áreas do direito não parecem fazer nem exigir essa pressuposição. ${ }^{142}$

Acredito que a resposta a essa pergunta é que o que o direito reivindica é obediência. A centralidade é da obrigação de obedecer e o descumprimento dessa obrigação é potencialmente sancionado. Quando pensamos em contratos, por exemplo, sua elaboração em desconformidade com as regras do Código Civil fará com que ele não gere direitos e obrigações para as partes e se alguma delas agir como se o contrato tivesse gerado tais direitos e obrigações ela poderá ser sancionada. O mesmo vale para cláusulas ilícitas no estatuto de uma sociedade. Não se trata apenas de dizer quais são as obrigações das autoridades - de cobrar, prender, coagir, etc. - mas de dizer quais são as obrigações dos cidadãos, cujo descumprimento essas autoridades terão o dever de sancionar.

Feito esse esclarecimento, podemos concordar com Keneth Himma que o direito autorizar a utilização da coerção é mesmo incontroverso, um fato que não levanta nenhuma questão conceitual. Mas dizer isso serve para destacar como o conceito doutrinal de direito “funciona para nós incorporado em uma prática que pressupõe que proposições jurídicas têm implicações para o exercício do poder" ${ }^{143}$ ou, em outras palavras, para mostrar como

a argumentação jurídica se dá sobre um platô de um vago consenso [rough consensus] de que se o direito existe ele oferece uma justificação para o uso coletivo do poder contra cidadãos individuais ou grupos. ${ }^{144}$

Dworkin pretende mostrar que não podemos fazer sentido do direito sem presumir essa justificação. ${ }^{145}$ Se nem em princípio essa justificação, pressuposta em nossas práticas, puder ser oferecida, então, como argumenta Stephen Perry "nossas práticas estão profundamente confusas e alguma coisa deu seriamente errado com nossos conceitos de autoridade e de direito"146.

142 GREEN, L. Associative Obligations and the State. In: BURLEY, J. Dworkin and his critics. Oxford: Blackwell Publishing, 2004, p. 281.

${ }^{143}$ DWORKIN, Introduction: Law and Morals, p. 19

${ }^{144}$ DWORKIN, Law's Empire, p. 108-109

145 "Unlike many before him, he does not try to show that law must have a unifying-and-distinctive purpose by showing what unifying-and-distinctive purpose law has. Rather, he tries to show that law must have a unifyingand-distinctive purpose by showing that we cannot make sense of law without assuming one." (GARDNER, J. Law's Aims in Law's Empire. In: HERSHOVITZ, S. Exploring Law's Empire: The Jurisprudence of Ronald Dworkin. Oxford: Oxford University Press, 2008. p. 208)

${ }^{146}$ PERRY, Law and Obligation, p. 295 
Levando em conta as consequências que se retira na prática de dizer $o$ que o direito $e ́$ - de que esteja autorizada a ameaça ou a utilização de coerção - isto é, a forma como funciona o conceito de direito ${ }^{147}$, parece, assim, menos arbitrária a afirmação de Dworkin de que as diferentes teorias do direito devem ser vistas como diferentes formas de justificar a coerção. Considerando as consequências que as proposições jurídicas têm para o exercício do poder, a pressuposição de que existe uma obrigação de obedecer, embora possa ser derrotada, é necessária para que possamos mesmo construir uma teoria do conceito doutrinal de direito. ${ }^{148}$

Se nos valemos de uma teoria do direito que é apenas uma teoria dos fundamentos do direito, porém, essa justificação será um non sequitur. O direito descrito por uma teoria preocupada apenas com seus fundamentos não pode ter qualquer consequência para a forma como devemos (cidadãos e autoridades) decidir o que fazer. Não podemos a partir de fatos que essas teorias estão identificando deduzir razões que justifiquem que alguém aja ou decida de alguma forma. ${ }^{149}$ No máximo, uma teoria sobre os fundamentos do direito poderia ser a teoria de um conceito sociológico de direito, conforme definido acima, o que pode ser ilustrado com o seguinte exemplo.

Imagine-se que em uma pesquisa sobre "as relações entre direito penal e saúde pública" o pesquisador parta do pressuposto que todos os dispositivos do Código Penal vigentes são parte do direito penal e, com isso, busque as relações entre o tipo penal de aborto (art. 124, CP) e gastos do SUS. Esse é um conceito possível, certamente inteligível e útil para a pesquisa, mas ele não diz nada sobre se a proibição ao aborto é ou não constitucional $^{150}$, i.e., se ela está ou não de acordo com o direito brasileiro. É um conceito construído independentemente de qualquer questionamento sobre a possibilidade de o direito

\footnotetext{
${ }^{147}$ A partir de um certo momento, sobretudo de Law's Empire, Dworkin passa a focar sua crítica ao positivismo no argumento de que os positivistas entendem mal que tipo de conceito o conceito doutrinal de direito é e oferece a categoria "conceito interpretativo" para classificá-lo. Apresentarei essa formulação do argumento anti-positivista de Dworkin no Capítulo 4, tentando, até lá, apresentá-lo independentemente dela, que, acredito, é apenas uma outra forma de fazer a mesma crítica que apresento neste capítulo.

148 "For us, a theory of doctrine is an indispensable part of, and nearly exhausts, a theory of adjudication not just because we believe in a moral obligation to obey the law but because, given our sense of how the doctrinal concept of law functions, we must suppose this in order even to construct a theory of legal doctrine" (DWORKIN, Introduction: Law and Morals, p. 19); Dworkin já apontava como nosso conceito de direito pressupor um dever de obediência pelos juízes em DWORKIN, R. O Modelo de Regras II. In: Levando os Direitos a Sério. Tradução de Nelson Boeira. $3^{\text {a }}$ edição. ed. São Paulo: WMF Martins Fontes, 2010, p. 79. ${ }^{149}$ NINO, C. S. Derecho, Moral, Politica. Doxa: Cuadernos de Filosofia del Derecho, v. 1, n. 14, Junho 1993 , p. 39-40.

${ }^{150}$ Questão pendente de julgamento pelo STF, na ADPF 442.
} 
gerar alguma obrigação. Por isso, se usado em um enunciado do tipo "de acordo com o direito brasileiro, o aborto é crime" não pode ter, per se, nenhuma consequência em uma discussão sobre o que qualquer cidadão ou autoridade pública deve fazer, salvo meramente como uma razão prudencial ${ }^{151}$ (caso pratique ou caso se omita na punição do ato, há chance de sofrer uma sanção, já que muitas vezes o descumprimento de normas do Código Penal gera sanções). Não é desse tipo de conceito de que tratamos quando divergimos sobre o que o direito exige em um caso concreto ${ }^{152}$.

Já a proposição de Dworkin de que as diferentes teorias do direito devem ser compreendidas como relacionadas a diferentes teorias da obrigação política significa dar ao conceito doutrinal de direito alguma força moral. Não se trata de descrever um fenômeno. ${ }^{153}$ É um fato que os tribunais brasileiros dizem que o aborto é crime e que o SUS funciona levando esse entendimento em consideração, mas essas são apenas descrições sobre atitudes de pessoas - juízes, gestores, médicos, enfermeiros. Sob um ponto de vista sociológico é possível, a partir dessas descrições, dizer que isso é o que prescreve o direito brasileiro. Mas quando se busca justificar como um juiz ou um ministro do STF deve decidir, afirmar que o direito brasileiro proíbe o aborto ${ }^{154}$ é tomar uma posição em um debate contra aqueles que dizem que, corretamente interpretado, o direito brasileiro garante à mulher a possibilidade de interromper sua gravidez. ${ }^{155}$

A pergunta sobre o que o direito é será respondida já pressupondo que essa resposta deve ter alguma consequência na forma como nós (cidadãos) devemos decidir o que fazer e

${ }^{151}$ Sobre a impossibilidade de razões prudenciais gerarem obrigações, ver RAZ, The Obligation to Obey the Law, p. 242-244 e DWORKIN, Levando os Direitos a Sério, p. 326

152 Como Dworkin já notava em O Modelo de Regras II, "Há uma objeção adicional que pode ser feita, mas que deixarei sem resposta. Não tenho resposta para o argumento de que o termo "direito" (law) pode ser usado de maneira que torne a tese positivista verdadeira por estipulação. Isto é, ele pode ser usado de tal maneira que aquele que fala somente reconheça como padrões 'jurídicos' aqueles que forem citados por juízes e juristas os quais, na verdade, são identificados por algum teste comumente aceito. Não há dúvida de que 'direito' pode ser usado dessa maneira e talvez alguns juristas procedam assim. Eu, porém, estava interessado no que considerei um argumento sobre o conceito de direito que é hoje de uso generalizado. Trata-se, penso eu, do conceito de padrões que estipulam os direitos e deveres que um governo tem o dever de (has a duty to) reconhecer e fazer cumprir (enforce), ao menos em princípio, através de instituições conhecidas como os tribunais e a polícia" (DWORKIN, O Modelo de Regras II, p. 75)

${ }^{153}$ GUEST, S. Ronald Dworkin. $3^{\text {a }}$ ed. Stanford: Stanford University Press, 2013. p. vii.

${ }^{154}$ Não estou me referindo às hipóteses em que o Código Penal expressamente afasta a ilicitude da conduta aborto necessário, para salvar a vida da gestante (art. 128, I, CP) e aborto no caso de gravidez resultante de estupro (art. 128, II, CP) - para os quais a licitude do aborto é muito menos controversa.

${ }^{155}$ Nesse sentido, respondendo a argumentos de Hart sobre a possibilidade de descrição do direito, cf. DWORKIN, R. Hart's Posthumous Reply. Harvard Law Review, v. 130, 2017, p. 2103; nesse artigo, Dworkin também diferencia a constatação de que a pena de morte é aplicada nos Estados Unidos com a afirmação (que ele entende equivocada) de que o direito americano, corretamente interpretado, a permite (ibid., p. 2099-2100) 
na forma como as autoridades (juízes, inclusive) devem exercer o poder. Será respondida de forma que possa tornar o direito capaz de gerar obrigações para os cidadãos (uma obrigação de obedecer ao direito) e, consequentemente, tornar legítima a utilização da coerção pelo Estado para que se faça cumprir tais obrigações (um direito de governar).

Para prover essa justificação, a identificação do direito não poderá ser feita meramente através de questões de fato - do tipo "o Congresso Nacional aprovou e o Presidente sancionou x" -, dependendo necessariamente de argumentos de moralidade política. Como conclui Nicos Stravopoulos,

A concepção de Dworkin é, portanto, fundamentalmente antitética a qualquer visão que pretenda explicar os fundamentos de direitos e obrigações jurídicos (isto é, dizer em virtude de quais fatos jurídicos mais básicos direitos e obrigações são criados e explicar como eles o fazem) sem apelar a fatores morais. ${ }^{156}$

Aqui está um primeiro argumento contra a possibilidade de teorias descritivas do direito. A partir do momento em que entendemos como funciona o conceito doutrinal de direito, como ele justifica atos muito concretos - por exemplo, os atos de negar a uma mulher um procedimento de interrupção de sua gravidez e, caso ela própria a interrompa, o ato de levá-la à prisão - não há espaço para uma posição desengajada de descrição de quais proposições jurídicas são corretas e quais não são. Não se trata apenas de avaliar $o$ que é central na prática, como Raz pretende com sua teoria e, sequer, apenas de identificar que a prática jurídica é "moralmente relevante"157, mas de enfrentar o cerne das questões de moralidade que se apresentam na prática jurídica. ${ }^{158}$

Trata-se, penso, de salvar a teoria do direito da irrelevância e da mistificação. Da irrelevância porque impede que a teoria foque-se na construção de um conceito de direito que não é capaz de dar nenhuma razão para que alguém decida em uma ou outra direção;

\footnotetext{
${ }^{156}$ STRAVOPOULOS, N. The Debate that Never Was. Harvard Law Review, v. 130, n. 2082, 2017, p. 2087

${ }^{157}$ Como defendido por Waluchow, que afirma que isso é feito pelo próprio Raz (WALUCHOW, Inclusive Legal Positivism, p. 22-23)

${ }^{158}$ Rubens Glezer tem a tese de que as divergências entre Raz e Dworkin (dentre outros críticos) têm, na verdade, raiz em uma divergência mais fundamental sobre o que se entende por prática social. Raz veria a prática como fato - que não constitui, por si só razões para agir (GLEZER, O Positivismo de Joseph Raz, p. 83 ) -, enquanto Dworkin veria a prática como racionalidade - segundo a qual para agir de acordo com uma prática é necessário entender qual é seu sentido, sentido este que dá razões para agir àqueles que dela participam (GLEZER, ibid., p. 76, 82). Glezer argumenta que essa divergência de fundo passa despercebida pelos participantes do debate, mas acredito que o argumento de Dworkin poderia ser visto, pelo menos da forma como eu o apresento, como uma crítica à compreensão da prática como fato e uma defesa da compreensão da prática como racionalidade.
} 
isto é, um conceito sem nenhuma relevância prática, fornecido pelo que Dworkin chama em Law's Empire de "uma teoria cuja única utilidade seria fornecer testes de memória para estudantes" ${ }^{159}$, uma teoria que, em busca de objetividade científica e rigor metodológico absoluto paga "o alto preço de se tornar uma teoria irrelevante e distanciada da prática" 160 . Da mistificação porque impede a teoria de construir um conceito que, descritivo, não deveria servir de fundamento para nenhuma decisão, mas que, na prática, assim funcionará a cada vez que uma autoridade derivar da afirmação de que "o direito é..." a justificativa para tomar alguma decisão que influenciará a vida de alguém.

Isso abre espaço para que a construção de uma teoria do direito seja consciente da importância do direito em nossa vida política e da ameaça e das oportunidades que ele pode representar para a questão fundamental e substantiva do respeito à dignidade dos cidadãos.

\subsubsection{TEORIA DO DIREITO E IGUALDADE}

Até onde isso nos leva? Se entendemos que é necessário que a teoria do direito trate da capacidade do direito de justificar a coerção, de sua força, então a pergunta fundamental que essa teoria terá que enfrentar é em que condições tal coerção não implicará subordinação, entendida como uma violação ao direito de igualdade que cada um possui.

Não quero aqui enfrentar a questão de se existe um direito à igualdade e o que ele implica, mas, supondo esse direito ${ }^{161}$, a "justificação da coerção" poderá ser reformulada como uma compatibilização da existência de autoridades estatais com a ideia de que os membros de uma comunidade política devem ser tratados de forma igualitária.

${ }^{159}$ DWORKIN, Law's Empire, p. 112

${ }^{160}$ BUSTAMANTE, T. A Breve História do Positivismo Descritivo - O que resta do positivismo jurídico depois de H. L. A. Hart? Novos Estudos Jurídicos , v. 20, 2015, p. 325

${ }^{161}$ Dworkin afirma que teorias da justiça tão diversas como seu liberalismo igualitário e o libertarianismo podem ser vistas como diferentes interpretações do que a igualdade - entendida como a ideia de que "os interesses dos membros da comunidade importam e importam igualmente" - exige. Essa espécie de consenso entre as teorias da justiça corresponde ao que ele chama de "platô igualitário", sobre o qual diferentes teorias da justiça seriam construídas (DWORKIN, R. Comment on Narveson: In Defense of Equality. Social Philosophy \& Policy, v. 1, n. 1, 1983, p. 24-25) e que exclui "posições políticas que foram outrora dominantes e ainda são populares em determinados círculos" (DWORKIN, R. Resposta aos Críticos. In: Levando os Direitos a Sério. Tradução de Nelson Boeira. $3^{a}$. ed. São Paulo: WMF Martins Fontes, 2010, p. 564), como teorias racistas, por exemplo. 
É nesses termos que Dworkin coloca a questão sobre a obrigação política. ${ }^{162}$ É necessário um governo para que possamos viver com dignidade ${ }^{163}$ - "a anarquia significaria o fim completo da dignidade"164 - mas um governo também pode ameaçar nossa dignidade ao nos forçar a aceitar seu domínio e ao nos tornar partícipes de um domínio injustificado sobre outros cidadãos. Nas palavras de Dworkin,

as organizações políticas coercitivas comprometem a dignidade de seus membros a não ser que cada um deles aceite uma responsabilidade recíproca para com os outros de respeitar as decisões coletivas e que tais decisões observem condições apropriadas. ${ }^{165}$

Tais "condições apropriadas" serão aquelas que permitam que as leis e políticas dos governos possam razoavelmente ser vistas como expressando "igual respeito e consideração" pelos membros da comunidade política ${ }^{166}$. Isso levando em conta tanto a forma como essas leis e políticas foram criadas - se os representantes foram eleitos, se o voto era universal, se as eleições não tiveram fraudes, se os juízes são escolhidos por métodos não discriminatórios ${ }^{167}$, etc. - quanto, o que é nosso objeto aqui, considerando a forma como o poder é exercido. ${ }^{168}$

É claro que essa resposta ainda deixa em aberto a questão de em que consiste esse "igual respeito e consideração"; na formulação de Dworkin, por exemplo, isso não significa igualdade distributiva ${ }^{169}$. Mas o importante é destacar como, a partir do momento em que entendemos o direito como justificação da coerção, a identificação de quais devem ser seus fundamentos precisará passar por esse tipo de questão substantiva de moralidade política. Em seu nível mais abstrato, a teoria de Dworkin é, portanto, derivada da ideia de igual respeito e consideração. Como conclui, Stephen Guest,

\footnotetext{
162 Joseph Raz também faz movimento semelhante ao relacionar sua "justificação normal” da autoridade com o valor da "autonomia" (cf. MURATA, Em Meio à Tempestade..., p. 116-121), mas essa relação não implica, dentro da teoria de Raz, nenhuma consequência para a forma como o direito deve ser identificado.

163 Dworkin oferece uma concepção de dignidade que se relaciona a dois princípios: autorrespeito e autenticidade (DWORKIN, Justice for Hedgehogs, p. 204). O autorrespeito corresponde ao reconhecimento de uma "importância objetiva" em viver bem (DWORKIN, ibid., p. 205) e a autenticidade corresponde a viver de acordo com os valores que se acha adequados (DWORKIN, ibid., p. 210).

${ }^{164}$ DWORKIN, Justice for Hedgehogs, p. 320

${ }^{165}$ DWORKIN, Justice for Hedgehogs, p. 319-320

${ }^{166}$ DWORKIN, Justice for Hedgehogs, p. 321-322

${ }^{167}$ Para um argumento sobre por que a escolha dos integrantes da Suprema Corte dos Estados Unidos não é antidemocrático, ver DWORKIN, Justice for Hedgehogs, p. 396-398.

${ }^{168}$ DWORKIN, Justice for Hedgehogs, p. 321 e p. 390.

${ }^{169}$ DWORKIN, Law's Empire, p. 403
} 
Qual é o sentido, ele [Dworkin] pergunta, de justificar uma ação em nome do direito a não ser que essa ação também tenha uma justificação moral? Essa é a principal preocupação da teoria moral e política de Dworkin e se apoia no que podemos chamar de seu princípio fundacional: que as pessoas deveriam ser tratadas com igual consideração e respeito. Quando estamos fazendo sentido do direito, devemos presumir que seu melhor sentido expressa uma igual consideração para com as pessoas. ${ }^{170}$

Assim, por exemplo, a defesa da integridade como concepção de direito deve ser entendida como uma defesa de que essa é a melhor forma de respeitar a dignidade dos cidadãos, cumprindo a obrigação de igual respeito e consideração para com eles. ${ }^{171}$

Perceber isso nos dá mais clareza do que realmente está em questão quando discutimos sobre casos controversos. Qual seria o problema, afinal, de tratar casos semelhantes de forma diferente? Se o STF decidiu que um índice que não recompõe a inflação viola o direito à propriedade e, por isso, não pode servir para correção monetária de precatórios $^{172}$, porque ele não poderia manter esse mesmo índice para correção de outros valores devidos pelo mesmo credor ${ }^{173}$ ? Ou, pensando na doutrina, por que não admitir que a forma como justificamos um ramo da responsabilidade civil seja simplesmente inconsistente com a justificação de outro? A razão não é simplesmente a "elegância teórica" ou o "rigor científico" da jurisprudência ou da teoria da responsabilidade civil que estamos construindo. A razão real é que não é essa a forma como uma comunidade comprometida com a igualdade deveria se governar ${ }^{174}$.

${ }^{170}$ GUEST, Ronald Dworkin, p. 19

${ }^{171}$ A integridade será atendida quando as responsabilidades que ela gerar forem compatíveis com uma “concepção plausível” de igual consideração (DWORKIN, Law's Empire, p. 201), requisito que pode ser criticado por ser pouco exigente. Por exemplo, argumentando-se que se é exigido apenas "plausibilidade" da concepção de igual consideração "we may expect that only if a community comes close to wearing its malice on its sleeve will the legitimacy of its institutions be denied" (RÉAUME, Is Integrity a Virtue?, p. 403) e que aceitar que a boa-fé pode gerar obrigações "seems like a recipe for perpetuating one of the most pernicious forms of oppression - pernicious precisely because it is so difficult to overcome in the face of its perpetrators' self-righteousness" (ibid., p. 405).

172 ADI 4357, julgada em 2014, em que foi julgada inconstitucional por "violação ao direito de propriedade" a utilização do índice de correção monetária da caderneta de poupança para correção monetária de precatórios.

${ }^{173}$ RE 870947, julgado em 2017, em que, pelos mesmos motivos, foi julgada inconstitucional a utilização do índice de correção monetária da caderneta poupança nas condenações judiciais impostas à Fazenda Pública.

174 “"....] We cannot simply ignore the claim that our purported justification would in fact show our legal practice to be unprincipled, because it appeals to a particular principle in justifying coercion against some citizens and rejects the same principle in denying compensation to other people. If that claim is justified, our proposed decision would be objectionable, not just as a matter of theoretical elegance, but also as a matter of how a community committed to equal citizenship should govern itself" (DWORKIN, R. In Praise of Theory. In: Justice in Robes. Cambridge: Harvard University Press, 2006, p. 53) 


\subsubsection{LEGITIMIDADE E CONTEÚDO DO DIREITO}

Tratei acima de como a categoria da validade costuma ser central a teorias que se ocupam apenas dos fundamentos do direito. Apresentado o argumento pela necessidade de também se levar em conta a força do direito, já podemos perceber o erro que existe em se considerar que Dworkin está tratando de validade. Sua preocupação é com conteúdo e, em última instância, com legitimidade ${ }^{175}$, legitimidade que corresponde justamente à força justificatória do direito.

Para ele, a legitimidade não é uma consequência de as normas jurídicas terem o "conteúdo correto"; não se trata, como venho dizendo, de primeiro identificar o direito e, depois, perguntar se ele é legítimo, em duas etapas bem delimitadas. Considerações de legitimidade influenciam a determinação das fontes e do conteúdo do direito. ${ }^{176}$ Isto é, determinar quais são as os direitos e as obrigações que as pessoas têm sob um determinado sistema jurídico não será feito somente através de fatos da história institucional daquela comunidade política; serão considerações de moralidade política - sobre legitimidade - que determinarão como esses fatos poderão criar direitos e obrigações. Chamando tais considerações morais de "fatos morais" 177 , Nicos Stravopoulos afirma que, nessa visão

os fatos morais são, portanto, os fundamentos do direito, mas não diretamente determinam seu conteúdo. Eles determinam como a prática institucional determina o direito, i.e., quais aspectos específicos da prática são relevantes para a contribuição da prática para o direito. ${ }^{178}$

A prática jurídica não poderá ser vista pelo teórico do conceito doutrinal de direito, portanto, "senão através das lentes da moralidade" ${ }^{179}$. Não é possível simplesmente descrevê-la a partir de fatos. ${ }^{180}$ Serão considerações de moralidade que determinarão, por exemplo, qual é o peso que deve ter a jurisprudência consolidada sobre uma matéria na forma

\footnotetext{
175 PRIEL, The Place of Legitimacy, p. 7

176 PRIEL, The Place of Legitimacy, p. 24; STRAVOPOULOS, The Debate that Never was, p. 2091

177 Tomo "fatos morais" como um simples sinônimo de "considerações de moralidade", o que entendo que é coerente com a dimensão interpretativa de tais considerações, dimensão da qual tratarei no capítulo seguinte.

${ }^{178}$ STRAVOPOULOS, Legal Interpretivism

${ }^{179}$ GUEST, How to Criticize Ronald Dworkin's Theory of Law, p. 356

${ }^{180}$ Essa é uma consequência da crítica de Dworkin à chamada “teoria da regra social”, que ele apresenta em $O$ Modelo de Regras II: "É verdade que os juízos normativos frequentemente supõem uma prática social como uma parte essencial do argumento em favor desse juízo; como afirmei esta é a marca registrada da moralidade convencional. No entanto, a teoria da regra social concebe de maneira equivocada essa conexão. Ela acredita que a prática social constitui uma regra que o juízo normativo aceita; na verdade, a prática social ajuda a justificar uma regra que é expressa pelo juízo normativo” (DWORKIN, O Modelo de Regras II, p. 91)
} 
como um tribunal decide e que importância devem ter os registros dos debates da Assembleia Constituinte de 1988 sobre a forma como nossa constituição é interpretada.

Uma teoria da obrigação política - como é a da integridade, por exemplo - será, assim, parte integrante de uma teoria sobre qual será o conteúdo do direito, de uma teoria sobre quais são seus fundamentos ${ }^{181}$, em uma relação de mútua implicação. Como resume Stephen Perry,

A resposta à questão de se temos ou não uma obrigação geral de obedecer ao direito de um sistema jurídico específico depende de se o conteúdo daquele direito, considerado como um todo, apresenta integridade, enquanto a questão de qual é o conteúdo do direito depende, em parte, de se o direito entendido como tendo este ou aquele conteúdo teria integridade (e, assim, faria surgir uma obrigação de obedecer ao direito). ${ }^{182}$

A noção de "validade" será ou irrelevante ou apenas uma forma de expressar que se chegou a uma conclusão sobre a identificação do conteúdo do direito ${ }^{183}$; por exemplo, em uma afirmação como "é válido o casamento entre pessoas do mesmo gênero no direito brasileiro" ou, no exemplo do próprio Dworkin, "constituições podem ser interpretadas como colocando os limites morais sobre que lei pode validamente ser criada naquela nação" 184 .

Mesmo problemas de "inconstitucionalidade formal", que poderiam ser descritos como problemas de validade, também devem ser remetidos a considerações de legitimidade. ${ }^{185} \mathrm{Um}$ exemplo é a questão das emendas às constituições estaduais por iniciativa do Legislativo em matérias em que, para leis, há iniciativa privativa do Executivo (art. 61, §1 $1^{\circ}, \mathrm{CF}$ ). Por mais que se fale que tais emendas são "inválidas”, essa afirmação é apenas a conclusão de um argumento sobre os limites do poder constituinte atribuído às assembleias legislativas (o chamado "poder constituinte decorrente") e sobre o significado da separação de poderes e do federalismo. ${ }^{186}$

\footnotetext{
${ }^{181}$ PERRY, Associative obligations and the obligation to obey the law, p. 7

182 PERRY, Associative obligations and the obligation to obey the law, p. 38

183 PRIEL, The Place of Legitimacy, p. 22

${ }^{184}$ DWORKIN, Introduction: Law and Morals, p. 6, grifei

${ }^{185}$ Agradeço a Jacqueline Abreu por chamar atenção para essa questão.

${ }^{186}$ Ver, nesse sentido, embora sem muita elaboração, ADI 3644, Relator: Min. Gilmar Mendes, Tribunal Pleno, julgado em 04/03/2009, especialmente a discussão sobre existência de tentativa de "burla" às regras de iniciativa pelas assembleias legislativas.
} 
O foco no conteúdo do direito em detrimento da categoria de validade também afasta a visão "taxonômica" do direito a que já me referi, segundo a qual o direito seria composto por um conjunto de normas (sejam regras, com estruturas do tipo "se x, então y", sejam princípios, com estruturas mais abertas) contáveis e individualizáveis. Não há um “teste de validade", independente de considerações de legitimidade, pelo qual tais normas possam passar. Assim como ocorre com o conceito de "validade", o conceito de "norma" (ou "regra") também servirá apenas para expressar que se chegou a uma conclusão. ${ }^{187}$

Os positivistas, por outro lado, tratam a questão da validade como prévia $e$ distinta da questão do conteúdo. ${ }^{188}$ Isto é, a definição do critério para saber se uma norma pertence ou não a um dado sistema jurídico não diz nada sobre qual é conteúdo dessa norma. Tratase de abordagem completamente diversa da adotada quando colocamos a legitimidade no centro das preocupações da teoria do direito.

\subsection{DIVERGÊNCIAS TEÓRICAS E POINT DO DIREITO}

Podemos, agora, voltar ao conceito de direito proposto por Dworkin e às perguntas que ele deduz desse conceito para entendermos como, respondendo-as, cada teoria do direito pressuporá uma diferente justificação ao enunciar os critérios de identificação do direito.

Como visto, o conceito proposto é de "esquema de direitos e responsabilidades que permitem a coerção porque decorrem de decisões passadas do tipo adequado" ${ }^{189}$. Esses “direitos e responsabilidades" são as permissões, proibições e obrigações de que tratamos acima, às quais se referem as proposições jurídicas. A "permissão da coerção" corresponde às atitudes do Estado para a aplicação dessas normas, desde prender alguém até pagar um benefício previdenciário (neste caso a coerção seria aplicada ao funcionário público que não

\footnotetext{
187 "Since it rejects the orthodox view that institutions communicate (or tacitly endorse) valid legal norms, pure interpretivism has no use for the orthodox notion of norms understood to play substantial explanatory roles (or for a metaphysically important notion of a law, as distinct from the informal notion that picks out statutes or other legislation) and is not a doctrine about conditions of validity. Legal norms (or rules or other standards) may figure in conclusions of reasoning that summarize the legal effect of institutional practice and are useful for exposition. Since standards so understood are derived from the explanation of the legal effect of practice, their existence is not constitutively responsible for the effect. They may also play an epistemic role: we may draw inferences about what rights and obligations exist from tried and tested formulations of standards, but the inferences are always subject to independent confirmation and the formulations are subject to revision" (STRAVOPOULOS, Legal Interpretivism, p. 9-10)

${ }^{188}$ PRIEL, The Place of Legitimacy, p. 7.

${ }^{189}$ DWORKIN, Law's Empire, p. 93
} 
fizesse cumprir uma determinação de pagamento, por exemplo). As “decisões passadas" são as leis (decisões do Congresso), decretos, portarias, instruções e instrumentos semelhantes (decisões do Executivo) e jurisprudência (decisões do Judiciário).

Como a essas decisões corresponde uma permissão para a coerção, a primeira pergunta será:

(i)

“A conexão entre direito e coerção é justificada? Existe algum propósito [point] em exigirmos que haja coerção apenas de acordo com o direito?"

Aqui, o teórico buscará responder se há alguma justificativa para que a coerção seja permitida apenas em nome dessas “decisões passadas". Responderá se é justificada a exigência de que a força seja utilizada apenas de acordo com o direito, independentemente de quão útil seja essa utilização e de quão benéfico ou nobres sejam os objetivos dessa coerção. ${ }^{190}$

Diante de uma resposta negativa - isto é, diante da resposta de que não há sentido em exigir que o Estado atue apenas de forma consistente a essas decisões passadas - a saída será pragmática: juízes e autoridades devem fazer o que for melhor para o futuro daquela comunidade política ${ }^{191}$. Não há razão para que o direito limite ou direcione o exercício do poder. Ainda voltarei a essa hipótese.

Por outro lado, sendo positiva a resposta, partimos para a segunda pergunta, que será:

$$
\text { “Se existe esse propósito [point], qual é ele?" }
$$

Podemos imaginar aqui uma infinidade de respostas. Uma possibilidade seria dar segurança aos cidadãos subordinados ao direito, isto é, previsibilidade. Outra seria a integridade, a concepção adotada por Dworkin, uma espécie de coerência em princípio ${ }^{192}$, que requer que o governo fale "com uma só voz", estendendo a todos os cidadãos os padrões de justiça que usa para alguns ${ }^{193}$.

\footnotetext{
${ }^{190}$ DWORKIN, Law's Empire, p. 93

${ }^{191}$ DWORKIN, Law's Empire, p. 95, tratando especificamente de juízes

192 "Integrity demands that the public standards of the community be both made and seen, so far as this is possible, to express a single, coherent scheme of justice and fairness in the right relation" (DWORKIN, Law's Empire, p. 219).

${ }^{193}$ DWORKIN, Law's Empire, p. 165
} 
É preciso esclarecer, contudo, o que se quer dizer com "propósito" - outras traduções possíveis seriam "intencionalidade" 194 e "sentido" - ou point, no original. Não se trata de uma função, que não tem nenhum papel justificador ${ }^{195}$. Não se trata da busca de um objetivo em termos de consequências ${ }^{196}$. Não se trata, tampouco, em qualquer sentido, de uma explicação histórica de "por que o direito foi criado"197. O point é um valor ${ }^{198}$ que é atribuído pelo intérprete ${ }^{199}$ àquela prática, procurando não explicá-la, mas justificá-la.

A atribuição desse point será, então, política, no sentido de oferecer uma justificação de legitimidade para o Estado, que aplica o direito e atua conforme o direito. Isso fica claro na conclusão de Dworkin em In Praise of Theory, quando ele justifica a importância do point que ele próprio atribui ao direito, a integridade:

[...] Então, minhas últimas palavras pretendem lembrar vocês de por que a integridade é tão importante. Cada democracia contemporânea é uma nação dividida, e nossa própria democracia [a americana] é particularmente dividida. Somos divididos cultural, étnica, política e moralmente. Nós, entretanto, aspiramos a viver juntos como iguais e parece absolutamente crucial a essa ambição que nós também aspiremos que os princípios sob os quais somos governados nos tratem como iguais. [...] Precisamos assumir esse dever soberano se reivindicamos um Estado de Direito [rule of law] que não é apenas um instrumento para conquistas econômicas e paz social, mas um emblema e espelho da consideração igualitária pública que nos dá o direito de reivindicarmos uma comunidade. ${ }^{200}$

${ }^{194}$ Como feito em MACEDO Jr., Do Xadrez à Cortesia.

195 “A função do direito constitui uma dimensão da ação que pode ser analisada externamente. Assim, podemos, por exemplo, afirmar que o direito contratual clássico cumpre a função de garantir o modo de produção capitalista. [...]A função, em certa medida, é externa à própria ação. [...] O elemento da intencionalidade a que se reporta Dworkin, contudo, não se define pela função. O point, ou elemento valorativo que guia ação, ao contrário, traduz outra dimensão, interna da ação e constitutiva desta. Ela mesma envolve um papel ativo do intérprete na 'imposição' de um valor ou de uma intenção [...]. (MACEDO Jr. Do Xadrez à Cortesia, p. 106107)

${ }^{196}$ Como Philip Soper pressupõe ao criticar a "escolha" de teorias do direito com base em suas consequências morais (cf. SOPER, P. Choosing a Legal Theory on Moral Grounds. Social Philosophy \& Policy, v. 4, n. 1, 1986); para uma crítica à utilização de critérios consequencias como argumento contra ou a favor de uma teoria do direito, cf. WALUCHOW, Inclusive Legal Positivism, p. 88-94.

${ }^{197}$ Law’s Empire, p. 52

${ }^{198}$ Raz critica Dworkin por supor que haveria apenas um valor a ser relacionado ao direito - "Seemingly, Dworkinian interpretation is conceived from the start as committed to strong monism, for it is committed to finding one purpose which unites and dominates all the parts of the interpreted object or practice (dominates, for in the post-interpretive stage, what the practice requires is adjusted to suit the imposed purpose)." (RAZ, The Relevance of Coherence, p. 315, rodapé omitido) - mas esse argumento pode ser afastado pela própria defesa que Dworkin faz da integridade como teoria do direito, que força que valores sejam compatibilizados e, ao mesmo tempo, permite que haja contradições entre diferentes áreas do direito (DWORKIN, Replies, p. 381).

${ }^{199}$ Essa atribuição de valor pelo intérprete não é um mero ato de vontade e está sujeita a uma série de limitações. Como afirmarei mais a frente, o intérprete deve apresentar uma justificativa para aquela prática e não inventar uma prática nova.

${ }^{200}$ DWORKIN, In Praise of Theory, p. 73-74 
Estabelecido esse propósito [point], a próxima pergunta será

$$
\begin{aligned}
& \text { "Que sentido de "decorrem de" [flow from] melhor serve a esse propósito } \\
& \text { [point]?". }
\end{aligned}
$$

É a resposta a esta última pergunta que dará os padrões para a identificação do direito (dará os fundamentos do direito) e, assim, determinará os "direitos e responsabilidades" que as pessoas efetivamente têm sob determinado sistema jurídico ${ }^{201}$.

Assim, se o point escolhido for a previsibilidade, os direitos e responsabilidades das pessoas serão aqueles previstos expressamente nos textos das "decisões passadas", pois, tendo acesso a esses textos, os cidadãos conseguiriam planejar suas ações já contando que eles seriam literalmente seguidos. Ou seja, a literalidade das decisões passadas seria o fundamento do direito porque esse fundamento seria o que melhor serviria ao point previsibilidade. Trata-se do que, em Law's Empire, Dworkin chama de convencionalismo ${ }^{202}$, que corresponderia a uma espécie de positivismo que, diferentemente do positivismo de Raz, é consciente da normatividade do conceito doutrinal de direito ${ }^{203}$. Alguém que defendesse esse point para o direito diria, então, que as decisões sobre casos controversos devem se basear no texto expresso de leis e outros instrumentos normativos e não em argumentos morais. Mas essa defesa não será baseada na natureza ou essência do direito e sim em um argumento moral substantivo sobre ser esta a melhor forma de dar legitimidade à coerção estatal. ${ }^{204}$

\footnotetext{
${ }^{201}$ A forma como identifica os direitos e deveres segue a estrutura que Dworkin apresenta, em Justice for Hedgehogs, para a interpretação em geral: "A particular interpretation succeeds - it achieves the truth about some object's meaning - when it best realizes, for that object the purposes properly assigned to the interpretive practice properly identified as pertinent. Interpretation can therefore be understood, analytically, to involve three stages. We interpret social practices, first, then we individuate those practices, when we take ourselves to be engaged in legal rather than literary interpretation. We interpret, second, when we attribute some package of purposes to the genre or subgenre we identify as pertinent, and, third, when we try to identify the best realization of that package of purposes on some particular occasion." (DWORKIN, Justice for Hedgehogs, p. 131). Como o próprio Dworkin destaca, embora essa estrutura tenha muito de artificial, ela é importante porque nos ajuda a focar na relação fundamental entre valor e critérios de interpretação (DWORKIN, ibid., p. 135).

202 DWORKIN, Law's Empire, p. 114-150.

${ }^{203}$ Por isso, também chamado de "positivismo político" (DWORKIN, Introduction: Law and Morals, p. 27)

${ }^{204}$ Dworkin faz esse argumento através do caso hipotético de responsabilidade civil de uma empresa de medicamentos. Se uma paciente não sabe de que empresa comprou um medicamento que gerou efeitos colaterais e há uma série de empresas que produzem esse medicamento, é possível que todas as empresas sejam acionadas conjuntamente? A resposta negativa a essa pergunta sob o fundamento de que não há previsão legal expressa de tal responsabilidade solidária depende de um argumento sobre por que apenas previsões expressas geram direitos e obrigações, relacionados a, por exemplo, argumentos sobre porque a eficiência e previsibilidade devem ser vistos como o point do direito. (DWORKIN, Introduction: Law and Morals, p. 914)
} 
Se, por outro lado, o point for a integridade, o direito deverá ser interpretado procurando consistência mesmo além do texto das normas, afastando, por exemplo, discriminações que não possam ser justificadas por alguma razão de princípio. As pessoas terão os direitos fundados nos princípios que melhor justificam a prática como um todo. ${ }^{205}$ A própria definição de quais são os materiais relevantes para a identificação do direito também dependerá do point que lhe foi atribuído na pergunta anterior. Como já destacado, considerações de legitimidade influenciarão a determinação das fontes do direito. ${ }^{206}$

Um exemplo pode ajudar a ilustrar como essa determinação dos direitos e responsabilidades que as pessoas têm é sensível à resposta anterior sobre qual é o point do direito. A reeleição para cargos do Executivo era proibida pelo texto original da Constituição de $1988^{207}$, até que a EC 16 de 1997 passou a permiti-la por uma vez, modificando o art. 14, $\S 5^{\circ}$ da Constituição ${ }^{208}$. Manteve-se, porém, o $\$ 7^{0209}$ do mesmo artigo, que prevê a inelegibilidade do cônjuge do chefe do Poder Executivo.

Uma abordagem convencionalista nos levaria à conclusão de que essa última regra deve ser aplicada em sua literalidade. Afinal, a EC 16 foi aprovada seguindo os procedimentos constitucionais, não tratou desse $\$ 7^{\circ}$ e é perfeitamente inteligível a regra de que o chefe do poder executivo poderá disputar uma reeleição, mas que seu cônjuge não pode disputar a eleição imediatamente posterior a seu mandato.

Por outro lado, se adotarmos uma abordagem de busca do sentido da mudança constitucional - propondo, por exemplo, que esse sentido seja de limitar alguma espécie de abuso de poder político -, pode parecer inconsistente ter se diminuído a restrição à reeleição de políticos, que são aqueles que efetivamente exercem o poder, e, ao mesmo tempo, terem sido mantidas restrições mais severas para seus cônjuges.

\footnotetext{
${ }^{205}$ DWORKIN, Law's Empire, p. 225

${ }^{206}$ PRIEL, The Place of Legitimacy, p. 24

${ }^{207}$ Art. 14. [...] $\S 5^{\circ}$ São inelegíveis para os mesmos cargos, no período subseqüente, o Presidente da República, os Governadores de Estado e do Distrito Federal, os Prefeitos e quem os houver sucedido, ou substituído nos seis meses anteriores ao pleito. (Redação original)

${ }^{208} \S 5^{\circ}$ O Presidente da República, os Governadores de Estado e do Distrito Federal, os Prefeitos e quem os houver sucedido, ou substituído no curso dos mandatos poderão ser reeleitos para um único período subseqüente. (Redação dada pela Emenda Constitucional no 16, de 1997)

${ }^{209} \S 7^{\circ}$ São inelegíveis, no território de jurisdição do titular, o cônjuge e os parentes consangüíneos ou afins, até o segundo grau ou por adoção, do Presidente da República, de Governador de Estado ou Território, do Distrito Federal, de Prefeito ou de quem os haja substituído dentro dos seis meses anteriores ao pleito, salvo se já titular de mandato eletivo e candidato à reeleição.
} 
Foi essa segunda abordagem a adotada pelo Supremo Tribunal Federal ao julgar o Recurso Extraordinário 344882 em 2003, sob o fundamento de que

o ordenamento jurídico e a Constituição, sobretudo, não são aglomerados caóticos de normas; presumem-se um conjunto harmônico de regras e de princípios: por isso, é impossível negar o impacto da Emenda Constitucional $n^{\circ} 16$ sobre o $\S 7^{\circ}$ do art. 14 da Constituição, sob pena de consagrar-se o paradoxo de impor-se ao cônjuge ou parente do causante da inelegibilidade o que a este não se negou $^{210}$.

E qual é o problema de "consagrar-se o paradoxo"? Supondo que entendamos que o melhor mesmo era proibir qualquer hipótese de reeleição, por que não permitirmos que se mantenha pelo menos essa vedação sub-ótima do $§ 7^{\circ}$ ? Mais uma vez, a resposta não é elegância teórica ou rigor científico. A resposta passa pela afirmação de alguma teoria como a integridade como point do direito e pela negativa de que uma teoria como o convencionalismo possa ocupar esse papel.

Trata-se de apenas um exemplo de como a escolha de uma teoria do direito específica, através da atribuição de um point ao direito, muda conclusões muito concretas sobre quais são os direitos e obrigações que o direito impõe. Esta é, porém, uma forma de explicar divergências na prática jurídica que não está disponível para uma teoria com pretensões apenas descritivas como a de Raz.

\subsubsection{CETICISMO, PRAGMATISMO E TEORIA DO DIREITO}

O exemplo citado acima parte do pressuposto de que existe um propósito [point] em se permitir a coerção apenas com base no direito. Pressupõe, assim, que algum argumento pela existência da obrigação política foi vitorioso (resposta à pergunta $i$ vista acima) e que juízes e cidadãos têm razões para entender que são justificadas as reivindicações de obediência feitas pelo direito. Mas e se não conseguíssemos construir esse argumento? E se, mesmo admitindo que o direito deve ser identificado de forma sensível a considerações de moralidade política, não conseguíssemos oferecer um fundamento para, sequer em princípio, justificar a afirmação de que apenas através do direito a coerção é justificada? 
Nesse caso, destituído o direito de qualquer força justificatória, a discussão sobre seus fundamentos será fútil e desinteressante e, como já apontei na Introdução, não teremos critérios para dizer que uma proposição jurídica é verdadeira ou não. Isto é, seríamos forçados a uma conclusão cética. Poderíamos até dizer que "de acordo com o Código Civil, x", mas isso não deveria ter nenhuma implicação prática na forma como qualquer pessoa (contratantes ou juízes) se comporta. Isso não significa, porém, que tribunais e o Estado em geral deixariam de existir. Como as autoridades deveriam se comportar no exercício de seus cargos?

Em Law's Empire, a resposta a essa pergunta corresponde a uma concepção de direito, que vai ganhar cada vez mais atenção de Dworkin em obras posteriores ${ }^{211}$, o chamado Pragmatismo: o teórico pragmático nega que decisões políticas passadas - como a aprovação de leis - possam, em si, oferecer qualquer justificação para que o Estado exerça ou deixe de exercer a coerção ${ }^{212}$. No exemplo de Waluchow, seria o caso de um teórico de alguma corrente marxista que entenda que o direito é apenas um disfarce para a opressão de classe, sem nenhum valor moral. ${ }^{213}$ Não necessariamente o teórico pragmático terá conscientemente analisado a reivindicação de legitimidade do estado e concluído que ela não é bem-sucedida, mas isso é o que estaria pressuposto em seu argumento.

Cada decisão deverá ser tomada isoladamente considerada sua justiça e eficiência, sem que o fato de ser consistente com determinada decisão passada (lei, sentença, decreto, etc.) acrescente qualquer coisa a tal análise. As divergências existentes na prática (e na teoria) dirão respeito, então, diretamente a divergências sobre justiça e sobre eficiência ${ }^{214}$ : se juízes divergirem a divergência não seria propriamente sobre o que o direito é, mas sobre o que é mais justo ou sobre alguma causalidade (eficiência).

Consequentemente, o pragmatismo nega que qualquer pessoa tenha realmente um direito em um sentido jurídico. Não seria possível que alguém fizesse jus a algo em razão de decisões legislativas passadas ou de jurisprudência consolidada quando isso fosse contrário aos interesses da comunidade como um todo. Para o pragmático, a referência a direitos e deveres jurídicos apenas se justificaria quando servisse à sociedade a longo prazo;

211 STRAVOPOULOS, The Debate that Never Was, p. 2084

212 Ressalvo que estou tratando de "pragmatismo" estritamente no sentido do termo proposto por Dworkin.

${ }^{213}$ WALUCHOW, Inclusive Legal Positivism, p. 14-15

${ }^{214}$ DWORKIN, Law's Empire, p. 151 
nestes casos, os juízes deveriam agir "como se" as pessoas tivessem esses direitos ${ }^{215}$, o conceito de direito subjetivo teria utilidade apenas de uma forma, nesse sentido, estratégica. O direito em geral também; os juízes deveriam geralmente seguir decisões passadas do Congresso pelos benefícios de coordenação e eficiência que decorreriam disso. ${ }^{216}$

Em resumo, conforme uma posição pragmática, não seria possível identificar nada chamado "direito" que devesse ter alguma influência na forma como autoridades e cidadãos devem ser comportar.

Essa descrição de um "pragmático hipotético" feita por Dworkin é relevante para entendermos que sua teoria do direito não implica igualar direito e moralidade ${ }^{217}$, nem desprezar as fontes institucionais do direito. Ao contrário, se respondermos positivamente à questão sobre a relação entre o direito e a coerção a ser justificada, então uma alta dose de conformidade será obrigatória. A justificativa para tal conformidade será, porém, moral. ${ }^{218}$

\subsubsection{O DIREITO INJUSTO É UM PARADOXO?}

A posição cética do pragmatismo é apresentada por Dworkin sem pressupor uma organização política marcada pela injustiça. Não é a situação extrema do "direito injusto", que aparece em perguntas como “o direito injusto é direito?” ou, em um exemplo comum de direito injusto, “os nazistas tinham direito?”. É desse tipo de pergunta que pretendo agora tratar.

Para Dworkin, o problema do direito injusto, embora ocupe um "lugar proeminente em seminários de teoria do direito", não tem "quase nenhuma importância prática"219.

\footnotetext{
${ }^{215}$ DWORKIN, Law's Empire, p. 152

${ }^{216}$ DWORKIN, Introduction: Law and Morals, p. 22.

${ }^{217}$ John Gardner, por exemplo, faz uma leitura equivocada nesse sentido: "How law is depends entirely on how it ought to be. Law is comprehensively tailored to its purpose" (GARDNER, J. Nearly Natural Law. The American Journal of Jurisprudence, v. 52, n. 1, 2007, p. 14-15). Como destaca Stephen Guest, "Which of two rival interpretations of a rule of law is better? For Dworkin, the one that more closely accords with the foundational principle [o princípio de que as pessoas devem ser tratadas com igual respeito e consideração]. But, contrary to a popular misunderstanding of Dworkin, this does not mean that in order to work out the law you merely make law into whatever is necessary to treat people as equals." (GUEST, Ronald Dworkin, p. 1920)

${ }^{218}$ MURATA, Em Meio à Tempestade, p. 180.

219 "an ancient jurisprudential puzzle of almost no practical importance that has nevertheless had a prominent place in seminars on legal theory" (DWORKIN, Justice for Hedgehogs, p. 410).
} 
Entender por que esse problema, que ocupa tanto os teóricos, é desimportante para Dworkin pode tornar mais claros os argumentos desenvolvidos até aqui.

Como tenho argumentado, conectar a identificação do direito - seus fundamentos com sua legitimidade - sua força - implica dissolver a diferença entre a pergunta sobre o que é o direito e sobre a obrigação de obedecê-lo. Assim, casos de "direito injusto" que, à primeira vista, aparentariam colocar um dilema podem ganhar uma resposta mais direta. Se supomos que o direito nazista é completamente ilegítimo, isto é, se as práticas dentro desse sistema não permitem que construamos nenhuma interpretação que possa ter algum poder justificatório ${ }^{220}$, então ele não será capaz de gerar nenhum direito ou obrigação ${ }^{221}$, que é o que importa saber quando tratamos do conceito doutrinal de direito. Falar que "mesmo assim ele é direito" poderá servir nessa situação apenas para algum tipo de análise sociológica; por exemplo, para saber como era organizado o Estado nazista. Mas disso não se pode retirar nenhuma conclusão sobre o que alguém - autoridade, juiz, cidadão - deve fazer. Mesmo assim, não poderíamos dizer que aquele que diz que os nazistas têm direito sem nenhuma outra qualificação está errado - nem que apenas ele está certo. Nossa linguagem é flexível o suficiente para admitir essas duas afirmações. ${ }^{222}$

Pensemos na situação do julgamento de oficiais nazistas que, seguindo regras colocadas por aquele governo, submeteram pessoas a tratamentos degradantes. Que diferença existe entre dizer que o direito nazista "não era direito" e que, portanto, os oficiais não poderiam utilizá-lo para escusar suas ações e dizer que o direito nazista era direito, mas era tão imoral que não era capaz de gerar obrigações de obedecer? Nenhuma diferença. Em ambos os casos, tudo o mais constante, as regras colocadas pelo governo nazista não devem ter nenhum impacto na forma como esses oficiais devem ser responsabilizados. ${ }^{223}$

\footnotetext{
${ }^{220}$ DWORKIN, Law's Empire, p. 102

${ }^{221}$ DWORKIN, Justice for Hedgehogs, p. 411; isso já aparecia em Modelo de Regras II como uma consequência da crítica de Dworkin à chamada "teoria da regra social": "Se alguém considera uma prática social sem sentido, tola ou insultuosa, ele poderá acreditar que nem mesmo em princípio ela justifica afirmar a existência de quaisquer deveres ou regras normativas de conduta. E nesse caso tal pessoa dirá não que a regra lhe impõe um dever que ela rejeita, mas que, apesar do que os outros pensam, não lhe impõe nenhum dever" (DWORKIN, O Modelo de Regras II, p. 92)

${ }^{222}$ DWORKIN, Law's Empire, p. 104

${ }^{223}$ Estou deliberadamente ignorando outras questões que poderiam surgir em um caso como esse, como a de coação sobre esses oficiais, de criação de obrigações ex post facto, etc. Essas questões se colocariam da mesma maneira em ambas as abordagens que estou apresentando.
} 
Em outros casos, o direito pode ser legítimo, mas o que se apresenta como sendo o direito que rege uma determinada situação pode, depois de uma análise mais atenta, revelarse como não sendo realmente direito por não satisfazer as condições de verdade que uma proposição jurídica deve satisfazer. Esse seria o caso de leis julgadas inconstitucionais. Para retomar o exemplo, seria o caso de alguém que diz que o direito brasileiro na verdade permite o aborto, mesmo que se trate de uma conduta tipificada no Código Penal.

Em ambos os casos, como aponta Stephen Guest, a questão para Dworkin "não é conceitual, mas uma questão de quais são os direitos que as pessoas podem exigir dentro de um estado"224. Isso é o que importa e é essa a pergunta que uma teoria do direito que não tem pretensões apenas descritivas deveria tentar responder. ${ }^{225}$

Mas vale perguntar se existiria uma terceira possibilidade. Não de um sistema jurídico que é todo ilegítimo, nem de uma lei injusta que não faz parte do direito bem compreendido identificado pela integridade, mas a possibilidade de uma lei que faz parte do direito identificado pela integridade e, mesmo assim, não gera um dever de obediência. Dworkin dá a entender que sim, que uma lei muito injusta poderia fazer parte do direito e que, mesmo fazendo parte do direito, haveria um direito de resistir a ela considerada sua injustiça. O exemplo que ele usa é da Fugitive Slave Act nos Estados Unidos, que dispunha que escravos fugitivos continuavam sendo escravos e deveriam ser capturados pelas autoridades. Nessa situação, a melhor descrição do que acontecia seria dizer que os proprietários de escravos tinham um direito de que seus escravos fossem capturados, mas que tal direito seria "derrotado" [trumped] $]^{226}$.

Há espaço para essa terceira possibilidade dentro da teoria de Dworkin? Trevor Allan diz que não, que ou a lei injusta faz parte do direito e retira dele toda a legitimidade ou ela simplesmente não faz parte do direito, identificado conforme a integridade. Ele afirma que seria inconsistente com a teoria de Dworkin uma obrigação apenas "prima facie" colocada

\footnotetext{
${ }^{224}$ GUEST, Ronald Dworkin, p. 105.

225 Tudo isso parece passar despercebido por Raz ao criticar Dworkin afirmando que para este "law can only modestly fail in its claims" sendo impossível que o direito seja totalmente ilegítimo (RAZ, On The Nature of Law, p. 113). Acredito que o erro está, mais uma vez, na confusão entre conceito doutrinal e conceito sociológico de direito.

${ }^{226}$ DWORKIN, Justice for Hedgehogs, p. 410-411
} 
pelo direito; não haveria espaço para, como Dworkin afirma, que em "casos muito raros" juízes tivessem a "obrigação moral de ignorar a lei quando ela é muito injusta"227.

A resposta a esse tipo de crítica está no argumento de Dworkin de que a legitimidade pode ter graus. Como ele afirma em Justice for Hedgehogs,

[...] embora as leis e políticas de um estado possam, em geral, mostrar uma tentativa de boa-fé de proteger a dignidade dos cidadãos, de acordo com alguma compreensão de boa-fé sobre o que isso significa, pode ser impossível reconciliar algumas leis e políticas específicas com essa compreensão. ${ }^{228}$

Em relação a leis como a Fugitive Slave Act não há uma obrigação de obediência por parte dos cidadãos e, não havendo essa obrigação, também não está um juiz justificado a aplicá-la ${ }^{229}$. Ainda dizemos que a lei faz parte do direito porque não conseguimos conciliar a afirmação de que ela não faz com o que identificamos serem os fundamentos do direito por exemplo, com uma ideia de supremacia do legislativo, apoiada, por sua vez, em um argumento sobre democracia e representatividade - e essa afirmação de que a norma é jurídica tem algum peso moral porque o Estado em questão não é completamente ilegítimo. É um exemplo, porém, de hipótese em que a legitimidade do estado está parcialmente comprometida e a desobediência civil será justificada ${ }^{230}$. Hipótese em que cidadãos e autoridades terão outras obrigações morais concorrentes às obrigações colocadas pelo direito, que podem, como vimos acima, ser derrotadas.

A admissão de que a legitimidade pode ter graus também leva a outras consequências. Em um caso de a legitimidade ser comprometida muito gravemente, mais do que a desobediência civil, a saída deve ser a revolução. ${ }^{231}$ Em casos menos graves, a integridade pode recomendar que aquele ato normativo específico seja aplicado, mas que,

${ }^{227}$ ALLAN, Law, Justice and Integrity, p. 727, citando DWORKIN, Introduction, Law and Morals, p. 18-19 ${ }^{228}$ DWORKIN, Justice for Hedgehogs, p. 322

${ }^{229}$ David Dyzenhaus vê uma inconsistência na posição de Dworkin sobre o direito injusto, porque ela permitiria que um juiz tivesse que aplicar uma lei que ele deve considerar parte do direito em relação a cidadãos que ele sabe que não deveriam considerar essa mesma lei como parte do direito. (DYZENHAUS, D. Dworkin and unjust law. In: WALUCHOW, W. J. The Legacy of Ronald Dworkin. Oxford: Oxford University Press, 2016, p. 154). Mas a identificação do direito e a aferição de sua legitimidade é uma só para todos os personagens dessa situação. Qualificar uma norma como jurídica em situações extremas como a do Fugitive Slave Act não implica nem um dever de obediência (pelo cidadão) nem um dever de aplicação (pelo juiz). Isso porque, ausente a obrigação de obedecer, a coerção estatal simplesmente não será justificada.

${ }^{230}$ DWORKIN, Justice for Hedgehogs, p. 323; tratei dessa questão em RIBEIRO, C. G. Desobediência Civil e Teorias do Direito. In: MACEDO JR. (org.), R. P. Teoria do Direito Contemporânea. Curitiba: Juruá Editora, 2017.

${ }^{231}$ DWORKIN, Justice for Hedgehogs, p. 323 
considerada sua inadequação com o esquema de princípios que melhor justifica o direito daquela comunidade, ele não deve ser estendido por analogia para casos diferentes; é o que Dworkin chama de negar ao ato normativo "força gravitacional" 232 . Mesmo em casos extremos de injustiça, como no sistema de apartheid da África do Sul, há relatos de que juízes, ao levar em consideração o papel justificatório do direito, apenas permitiam discriminações raciais quando leis expressamente as previssem, negando que houvesse um "princípio geral discriminatório" no direito sul-africano do qual seriam deduzidos novos direitos e obrigações ${ }^{233}$, isto é, negando "força gravitacional” às diversas leis que previam práticas discriminatórias.

O problema do direito injusto pode, portanto, trazer alguns esclarecimentos sobre o que uma teoria do direito pode ser, mas, diferentemente do que uma teoria com pretensões estritamente descritivas poderia supor, não coloca nenhum paradoxo. Levando em consideração o papel justificatório que o direito tem, a pergunta sobre se o direito injusto é ou não direito se mostra, embora persistente, mal colocada.

\subsection{O DIREITO ALÉM DOS TRIBUNAIS}

Tenho me referido repetidamente à identificação do direito feita não só por juízes, mas também por outras autoridades e, principalmente, pelos cidadãos. Isso é importante para destacar que uma teoria que procura apresentar o direito como justificação para a coerção não é uma teoria que se aplique apenas à definição das responsabilidades dos juízes, mas uma teoria que se aplica à definição de quais são os direitos e as obrigações dos cidadãos em geral. Isso vale para qualquer teoria que reconheça o papel justificatório do direito, mas é ainda mais reforçado pela adoção da concepção de direito proposta por Dworkin, a do direito como integridade.

Pensemos inicialmente na adoção de uma concepção convencionalista de direito. Essa concepção é fundamentada por um argumento de segurança jurídica e previsibilidade,

${ }^{232}$ DWORKIN, R. Casos Difíceis. In:

Levando os Direito a Sério. São Paulo: WMF Martins Fontes , 2002, p. 189; um exemplo talvez seja a não extensão de normas colocadas pela recente Reforma Trabalhista (Lei 13.467/17) que se entenda incompatíveis com princípios centrais ao Direito do Trabalho relacionados à proteção do trabalhador como hipossuficiente. O aforismo de que "restrições a direitos fundamentais são interpretadas restritivamente" também é um exemplo nesse sentido.

${ }^{233}$ CHASKALSON, A. From wickedness to equality: the moral transformation of south african law. Institutional Journal of Constitutional Law, v. 1, n. 4, 2003, p. 595. 
capaz de gerar uma obrigação de obedecer para os cidadãos. Se existe uma obrigação de obedecer ao direito identificado como um conjunto de decisões esparsas que passam por procedimentos específicos, como o processo legislativo e o processo judiciário, caberá, então, a cada cidadão e a cada autoridade reconhecer nessas decisões seus direitos e deveres como membros de uma comunidade política. Nas suas relações que sejam diretamente regidas por essas decisões, os cidadãos deverão observar as diretivas colocadas por elas; nas demais relações, o direito não colocará nenhuma obrigação. ${ }^{234}$ Ou seja, mesmo adotada essa concepção convencionalista, não é correto dizer que a identificação do direito deverá ser feita apenas por juízes.

Caso adotemos uma concepção de direito como integridade, o papel de cada cidadão na identificação do direito será ainda mais acentuado. A obrigação política de cada um passará a ser não apenas uma obrigação de obedecer uma a uma decisões específicas, mas uma questão de "fidelidade a um esquema de princípios que cada cidadão tem a responsabilidade de identificar, em última instância para si próprio, como o esquema de princípios da comunidade" ${ }^{235}$. Nas palavras de Dworkin,

a integridade demanda do bom cidadão, decidindo como ele tratará seu vizinho quando seus interesses conflitem, que interprete o esquema comum de justiça ao qual ambos estão comprometidos simplesmente em virtude de serem cidadãos ${ }^{236}$.

Trata-se de o que ele chama de uma atitude protestante em relação à política em seu sentido mais amplo. ${ }^{237}$ Cada cidadão deverá ver suas obrigações dentro de sua comunidade como questões de justiça ${ }^{238}$ e a comunidade oferecerá a ele a oportunidade de que leve tais questões a um órgão, como um tribunal, que considerará seriamente suas razões. ${ }^{239} \mathrm{O}$ mesmo

\footnotetext{
${ }^{234}$ DWORKIN, Law's Empire, p. 189

${ }^{235}$ DWORKIN, Law's Empire, p. 190.

${ }^{236}$ DWORKIN, Law's Empire, p. 189-190

${ }^{237}$ DWORKIN, Law's Empire, p. 413; para uma crítica a essa atitude protestante a partir da dificuldade de identificar os princípios subjacentes à prática jurídica pelos cidadão e da maior adequação do discurso político (ao invés do direito) para expressar princípios de justiça em geral, cf. MURPHY, L. The Political Question. In: COLEMAN, J. Hart's Postscript: Essays on the Postscript to the Concept of Law. Oxford: Oxford University Press, 2001 p. 405-408

${ }^{238}$ Um argumento semelhante é feito por John Rawls, ao tratar do tema da desobediência civil: "In justifying civil disobedience one does not appeal to principles of personal morality or to religious doctrines, [...] Instead one invokes the commonly shared conception of justice that underlies the political order. It is assumed that in a reasonably just democratic regime there is a public conception of justice by reference to which citizens regulate their political affairs and interpret the constitution. [...]" (RAWLS, A Theory of Justice, p. 321).

${ }^{239}$ Cf. DWORKIN, R. Political Judges and the Rule of Law. In: A Matter of Principle. Cambridge: Harvard University Press, 1985, p. 32, em que Dworkin defende a ideia da atitude protestante, embora sem essa denominação, como uma concepção de "rule of law".
} 
vale para uma autoridade do Poder Executivo na interpretação de quais são suas responsabilidades jurídicas. Essa interpretação também deverá ser fiel ao "esquema de princípios" da comunidade e se submeterá, nesses termos, ao controle de um órgão responsável por aplicar o direito, como um tribunal.

É verdade que ao identificar quais são as obrigações que o direito coloca o cidadão deve se colocar em uma posição hipotética de um juiz ou de alguma autoridade em posição semelhante. $\mathrm{O}$ direito será o que, desse ponto de vista, ele deve identificar. ${ }^{240}$ Mas essa é apenas uma consequência da afirmação de que os juízes devem reconhecer os direitos e as obrigações que as pessoas têm. A decisão do juiz, em regra, deverá ser cumprida por ser a decisão de uma autoridade estatal, mas a atitude protestante permite que o cidadão argumente que, ainda assim, o direito está ao seu lado. Pode haver, isto é, uma deferência política (se moralmente justificada) mas não uma deferência cognitiva ${ }^{241}$ (sobre alguma instituição ter o monopólio da verdade quanto ao que é o direito ${ }^{242}$ ) em relação às decisões de algum órgão como um tribunal. Autoridades (juízes, inclusive) e cidadãos devem utilizar os mesmos parâmetros para identificar o que o direito é. Isto é, em ambos os casos os fundamentos do direito serão os mesmos.

Não é apenas uma feliz coincidência que a identificação do direito e da obrigação de obedecê-lo seja feita da mesma maneira por cidadãos e autoridades. Se estamos preocupados com legitimidade, uma obrigação de obedecer (dos cidadãos) deve corresponder necessariamente a um direito de governar (do Estado).

Com isso, já poderíamos afastar o argumento de Raz de que a teoria do direito de Dworkin é apenas uma teoria da adjudicação, entendida como uma teoria voltada apenas à identificação do direito por juízes ${ }^{243}$. Mas é importante ressaltar que, na verdade, não se trata,

\footnotetext{
${ }^{240}$ Voltarei a esta questão no último capítulo.

${ }^{241}$ DWORKIN, Replies, p. 386

${ }^{242}$ A ausência de tal monopólio não implica que não exista resposta certa para questões jurídicas controversas. Dworkin afirma que Leslie Green faz essa confusão entre a afirmação da "responsabilidade protestante" de cada cidadão de identificar o direito e a afirmação de que não existe uma resposta certa para questões jurídicas (DWORKIN, Replies, p. 379). Para o argumento de Dworkin sobre a existência de uma resposta certa para casos difíceis, cf., por exemplo, DWORKIN, Is There Really No Right Answers in Hard Cases? em A Matter of Principle.

${ }^{243}$ RAZ, Two Views of the Nature of the Theory of Law, p. 75; um argumento semelhante é feito por Waluchow, que afirma, ainda, que Dworkin trata de direitos subjetivos que os cidadãos teriam contra os juízes (WALUCHOW, Inclusive Legal Positivism, p. 48-49), além de pelas razões expressas acima, acredito que esse argumento está incorreto porque os cidadãos têm direito contra o Estado e não contra a pessoa que naquele momento ocupa a função de magistrado naquela jurisdição.
} 
sequer, necessariamente de uma teoria que se aplique aos juízes. Como afirma Dworkin, não se segue de suas afirmações sobre a necessidade de justificação na identificação do direito que um tipo de autoridade em particular, como os juízes, deva ter a responsabilidade de fazer esse esforço de justificação em alguma ocasião em particular. ${ }^{244}$ É verdade que em Justice for Hedgehogs Dworkin define direitos “jurídicos" como aqueles que são "aplicáveis [enforceable] a pedido [on demand] em uma instituição adjudicatória tal como um tribunal" 245 , mas essa "instituição adjudicatória" não precisa corresponder ao Judiciário e mesmo que corresponda a ele, não precisa corresponder a todos os membros do Judiciário exatamente como ele é hoje no Brasil ou nos Estados Unidos.

A atribuição de competência a diferentes autoridades é sujeita a uma série de contingências de cada comunidade política. É trivial que juízes em diferentes países e mesmo dentro de um mesmo país têm diferentes competências. No Brasil, por exemplo, qualquer magistrado de primeira instância pode, com eficácia inter partes, declarar uma lei inconstitucional, um magistrado de segunda instância não pode fazê-lo sem observar a regra da reserva de plenário - remetendo a questão ao Pleno ou ao Órgão Especial de seu tribunal (art. 97, CF) - e o Pleno do STF pode fazê-lo com eficácia erga omnes (art. 102, I, a), CF). Isso significa que seria necessária uma teoria do direito diferente - prescrevendo diferentes fundamentos do direito, com diferentes formas de se aferir a verdade de proposições jurídicas - para cada um desses magistrados? Dworkin diz que, considerando que uma corte inferior deve ter um respeito por precedentes que uma corte superior não está obrigada a ter, é possível dizer que o direito é diferente para cada uma dessas cortes, mas que também é possível dizer que o direito é "realmente" o que deve ser aplicado pela corte superior, que tem a última palavra. A flexibilidade da nossa linguagem permitiria ambos esses tipos de exposição. ${ }^{246}$ Para o que importa à análise do conceito doutrinal de direito, que diz respeito aos direitos e obrigações que as pessoas efetivamente têm, entendo, entretanto, que o correto é dizer que o direito é um só e pode ser identificado com aquilo que deveria decidir a instituição adjudicatória que tem a última palavra sobre ele.

\footnotetext{
${ }^{244}$ DWORKIN, In Praise of Theory, p. 56

${ }^{245}$ DWORKIN, Justice for Hedgehogs, p. 404-405, existe um argumento contra essa definição, segundo o qual obrigações não "enforceable", como obrigações dos legisladores, cujo descumprimento não gera sanção, também deveriam ser consideradas jurídicas (SAGER, L. G. Putting Law in Its Place. In: WALUCHOW, W. J. The Legacy of Ronald Dworkin. Oxford: Oxford University Press, 2016), de que tratarei no Capítulo 4.

${ }^{246}$ DWORKIN, Law's Empire, p. 453
} 
Com isso, quero destacar que dizer o que o direito é não equivale necessariamente a dizer o que qualquer juiz deve fazer. Há uma série de constrangimentos (eles mesmos jurídicos) a que diferentes juízes estão submetidos ${ }^{247}$, que limitam os assuntos sobre os quais eles podem decidir (como divisões de competência por matéria) e as considerações eles podem utilizar para decidir (como no exemplo das decisões fundamentadas na declaração de inconstitucionalidade de uma lei).

Isso quer dizer que nada do que foi dito até aqui nos impede de construir o argumento de que os juízes, como são hoje selecionados, via concurso públicos e indicações, não estão capacitados a terem todo o poder que lhes é atribuído ${ }^{248}$, isto é, o poder de identificar corretamente o direito e aplicá-lo. Nas palavras de Dworkin,

[s]e a comunidade diz a um juiz "A Constituição é a lei maior e seu trabalho é dizer o que a Constituição significa", então, como eu tenho frequentemente tentado argumentar, essa instrução acabará exigindo uma "incursão" muito considerável em moralidade política. Mas nós não precisamos instruir nossos juízes dessa forma. É perfeitamente inteligível que nossos juízes não devam ser encarregados de ter a interpretação final e autoritativa da Constituição. ${ }^{249}$

Críticas a um suposto ativismo judicial que prescrevem uma determinada forma de identificação do direito como remédio, geralmente recomendando leituras mais literais dos dispositivos legais, cometem, assim, uma séria confusão ao misturar a questão das capacidades institucionais dos magistrados com a questão de o que é o "raciocínio jurídico". 250

Seria possível, por exemplo, aceitar o que Dworkin chama de "leitura moral" da Constituição, segundo a qual a constituição americana torna obrigatórios uma série de princípios morais, e afirmar, ainda assim, que juízes não devem ter a autoridade para

\footnotetext{
${ }^{247}$ Waluchow sugere que esses constrangimentos deveriam levar a teoria do direito a trabalhar com a categoria "força institucional" ao lado das categorias "fundamentos do direito" e "força do direito" propostas por Dworkin (WALUCHOW, Inclusive Legal Positivism, p. 37). Acredito, entretanto, que essa categoria é desnecessária quando entendemos que questões processuais (inclusive de competência) também são questões jurídicas, que também devem ser identificadas conforme a integridade ou outra teoria normativa.

${ }^{248}$ Há espaço, portanto, para um argumento como o de Carl Sunstein sobre a falta de "capacidade institucional" do Judiciário sem que, como ele pretende, o interpretativismo de Dworkin precise ser abandonado. Para uma apresentação do debate entre Dworkin e Sunstein, cf. PASCHOALINI, F. Interpretação e Instituições: O Diálogo entre Cass Sunstein e Ronald Dworkin. In: MACEDO JR., R. P. (org.). Teoria do Direito Contemporânea. Curitiba: Juruá Editora, 2017.

${ }^{249}$ DWORKIN, In Praise of Theory, p. 56-57

${ }^{250}$ DWORKIN, In Praise of Theory, p. 57
} 
proceder a essa leitura. ${ }^{251} \mathrm{O}$ melhor desenho institucional será aquele que atribuir tal autoridade à instituição que tem mais chances (está mais capacitada) de chegar às melhores respostas sobre questões morais ${ }^{252}$, que pode não ser uma instituição como a Suprema Corte nos Estados Unidos ou o Supremo Tribunal Federal no Brasil.

A identificação do direito dirá respeito, portanto, uma vez que aceitamos seu papel justificatório, a cada cidadão e autoridade. Se o que buscamos é a construção de uma teoria que identifique o direito de forma a tornar-lhe legítimo criando uma obrigação de obedecêlo, então não podemos admitir que tal identificação seja monopólio dos tribunais e seja realizada mediante considerações de moralidade que se apliquem somente a eles.

\subsection{UMA TEORIA QUE NOS DIGA O QUE FAZER: CONTINUIDADE ENTRE TEORIA E PRÁTICA}

Vimos que as diferentes teorias do direito correspondem a diferentes maneiras de justificar a coerção estatal e fundamentar uma obrigação política. Também destaquei que essa compreensão do papel da teoria do direito como justificação é uma diferença fundamental da abordagem de Dworkin em relação a seus críticos positivistas especialmente $\mathrm{Raz}$-, que pretendem oferecer uma teoria do direito meramente descritiva.

Isso nos leva a mais uma diferença fundamental entre a abordagem dworkiniana e a de seus críticos: a defesa da inexistência de uma diferença substancial entre a teoria e a prática do direito. ${ }^{253}$ Diferentemente da teoria de Raz, a teoria de Dworkin pretende ter uma influência direta sobre a prática jurídica, especialmente sobre a atividade dos juízes. Tratase, precisamente, do contrário das ambições de uma teoria como a de Raz, que, como visto, é explícita em diferenciar a identificação do direito das responsabilidades daqueles que têm

\footnotetext{
${ }^{251}$ DWORKIN, R. Introduction. In: Oxford: Oxford University Press, 1996, p. 12

${ }^{252}$ DWORKIN, ibid., p. 34; cf. também, defendendo esse argumento de Dworkin das críticas de Jeremy Waldron, FERNANDES, R. B. Controle de Constitucionalidade e Democracia no debate entre Ronald Dworkin e Jeremy Waldron. Trabalho de Conclusão de Curso, Faculdade de Direito da Universidade de São Paulo. São Paulo. 2013.

253 " [...] it is impossible to distinguish the two kinds of claims - to distinguish the first-order claims of lawyers in legal practice from second-order philosophers' claims about how first-order claims are to be identified and tested - sufficiently to assign them to different logical categories" (DWORKIN, R. Hart's Postscript and the Point of Political Philosophy. 2006, p. 164)
} 
a função de aplicá-lo e pretende não ter nenhuma consequência sobre como a prática jurídica é conduzida. ${ }^{254}$

Para Dworkin, o mesmo tipo de consideração sobre o direito que ocupa (ou que deve ocupar) os teóricos também ocupa os tribunais, as autoridades e os cidadãos ${ }^{255}$. Em suas palavras, a teoria do direito é o "prólogo silencioso de qualquer decisão no direito" 256 . Mas o que isso quer dizer?

Vimos que a melhor concepção (teoria) do direito será aquela que melhor realizar a conexão entre os critérios de verdade das proposições jurídicas (os fundamentos do direito) e a obrigatoriedade moral dessas proposições (a força do direito). As diferentes teorias do direito serão, assim, dependentes de diferentes teorias sobre a legitimidade da coerção estatal e, levando estas últimas em consideração, darão os critérios para a identificação do direito.

Tal conclusão não nos leva apenas a conectar as teorias do direito à questão da legitimidade. Também a prática jurídica será compreendida sob essa luz. Quando uma autoridade (inclusive um juiz) fundamenta uma decisão na afirmação de o que o direito é, estará pressuposta aí uma forma de identificar esse direito - uma teoria sobre os fundamentos do direito - que, por sua vez, será dependente de uma teoria que faça a justificação da coerção através do direito. A teoria do direito é o prólogo silencioso de qualquer decisão judicial porque ela que pode dar sentido a essa decisão. Isto é,

porque é a teoria do direito que pode explicar como os atos coercitivos do Estado - incluindo aqueles envolvidos na decisão judicial - são (potencialmente) legítimos e não apenas força respaldada por uma ameaça de punição ${ }^{257}$

Assim, as divergências que se dão na prática jurídica - ou, pelo menos, as divergências que não digam respeito a questões de fato - também devem ser compreendidas como divergências que podem ser reportáveis, em última instância, a divergências sobre

254 “Under Joseph Raz, and a number of his students, three of whom are professors of legal philosophy with Raz at Balliol College, Oxford, legal philosophy is a non-normative, non-sociological and 'conceptual' subject that, according to Dworkin's successor at Oxford, makes a virtue of being 'uninteresting' in the sense that it is not intended to have impact on cases" (GUEST, Ronald Dworkin, p. 7)

255 " [...] a judge or citizen who has to decide what the law is on some complicated issue must interpret past law to see what principles best justify it, and then decide what those principles require in the fresh case. So a legal philosopher's theory of law is not different in character from, though it is of course much more abstract than, the ordinary legal claims that lawyers make from case to case" (DWORKIN, R. Hart's Postscript and the Point of Political Philosophy. 2006, p. 141)

${ }^{256}$ DWORKIN, Law's Empire, p. 90

${ }^{257}$ PRIEL, The Place of Legitimacy..., p. 23 
legitimidade para que se possa fazer sentido da prática jurídica como algo diferente de um exercício arbitrário de força.

Como nota Perry, uma vez que adotemos a integridade como melhor concepção do direito, "a questão de qual é o conteúdo do direito dependerá, em parte, de se o direito entendido como tendo ou não esse conteúdo teria integridade (e, portanto, daria origem a uma obrigação geral de obedecer)" ${ }^{258}$. Aceitando o conceito de direito como justificação da coerção, a adoção de qualquer outra teoria não cética do direito nos levaria ao mesmo tipo de questão.

Raz vê esse argumento de Dworkin como exagerado. Ele afirma que o juiz americano que precisa decidir "pressupõe, talvez, algo sobre o direito americano" 259 , mas que não precisa pressupor muito. O juiz "não precisa fazer nenhuma pressuposição sobre o conteúdo do resto do direito ou sobre a forma de estabelecê-lo quando ele acredita que isso não fará nenhuma diferença para o caso diante dele" ${ }^{260}$. O que se pode argumentar contra isso?

Um primeiro argumento, traçado pelo próprio Raz, seria a reformulação da tese de Dworkin: não se trata de dizer o que os juízes pressupõem ao julgar, mas de dizer o que deve ser verdadeiro para que suas decisões possam ser corretas. Isto é, a tese do "prólogo silencioso" significaria que os juízes devem se basear em uma concepção correta de o que o direito é para que suas decisões possam ser corretas, não quer dizer que eles efetivamente o façam.

O erro nessa tese reformulada estaria, para Raz, em pressupor que o dever dos juízes ao decidir casos compreende dois estágios, um estágio em que se estabelece o que o direito é (através da filosofia do direito) e um segundo estágio em que essas conclusões são aplicadas para determinar seu conteúdo. No limite, seria possível, argumenta Raz, pensar em tribunais que aplicam regras de direito e não têm consciência de que existe um conceito de direito. O conceito de direito é mais recente do que as instituições que ele pretende identificar e "nosso conceito de direito não faz da consciência dele em uma sociedade uma pré-condição para que essa sociedade seja governada pelo direito" ${ }^{261}$. Em outras palavras, uma sociedade

${ }^{258}$ PERRY, Associative obligations and the obligation to obey the law p. 38.

${ }^{259}$ RAZ, Two Views of the Nature of the Theory of Law, p. 83

${ }^{260}$ RAZ, Two Views of the Nature of the Theory of Law, p. 84

${ }^{261}$ RAZ, J. Can There Be a Theory of Law? In:

Between Authority and Interpretation - On the

Theory of Law and Practical Reason. Oxford: Oxford University Press, 2009, p. 40. 
pode ser governada por regras e instituições, não ter a percepção dessas regras e instituições como sendo direito e, mesmo assim, essas regras e instituições podem ser explicáveis por meio de nosso conceito de direito. ${ }^{262}$ É possível imaginar que, historicamente, uma série de instituições aplicavam algo que hoje chamaríamos de "direito" sem ter esse conceito. O erro estaria em presumir que a filosofia do direito cria um conceito de direito quando, na verdade, ela apenas explica um conceito que existe independentemente dela. ${ }^{263}$

Como temos visto até aqui, em um certo sentido, a filosofia do direito cria sim o conceito de direito - uma concepção do conceito doutrinal de direito conforme a terminologia de Dworkin ${ }^{264}$. No sentido de que o conceito de direito funciona como uma justificação para o exercício do poder e, assim entendido, caberá ao teórico fazer com que essa justificação faça sentido ou, caso isso não seja possível, concluir que esse conceito está sendo usado incorretamente e não deveria justificar coisa nenhuma. Para fazer sentido dessa justificação que o direito pretende oferecer, é preciso que a atividade de um juiz seja entendida como pressupondo uma certa teoria do direito, por mais que alguns juízes - ou mesmo a maioria dos juízes - não possam articular a teoria do direito em que se baseiam.

A autoconsciência sobre o conceito de direito pode não ser importante quando estamos tratando de algum conceito sociológico de direito, mas quando tratamos do conceito doutrinal ela é fundamental. Nosso empreendimento teórico diz respeito a algo que é invocado para justificar o uso ou a ameaça de coerção, o direito, em instituições que são criadas com essa finalidade, como tribunais. Isto é, é necessário que, ao decidir, o juiz pelo menos pretenda estar oferecendo uma decisão de acordo com o direito, mesmo que não possa articular qual seria a teoria subjacente à forma como identificou o direito naquele caso concreto.

Uma última crítica contra a tese da continuidade entre teoria e prática que vale a pena abordar é a de que uma teoria como a de Dworkin serviria apenas para os "casos difíceis", aqueles em que divergem juízes, juristas e opinião pública e que, geralmente, têm grandes consequências sociais. Os “casos fáceis", continua a crítica, não têm nenhuma relação com todo esse argumento sobre legitimidade. Um juiz não precisa saber articular qual é a teoria

${ }^{262}$ RAZ, J. On The Nature of Law, p 39

${ }^{263}$ RAZ, Two Views of the Nature of the Theory of Law, p. 84-85

${ }^{264}$ Como tratarei mais à frente, para Dworkin, "a successful conception of an interpretive concept is indeed something new" (DWORKIN, Justice for Hedgehogs, p. 180) 
do direito subjacente à decisão em que ele reconhece que é devida uma multa de trânsito, situação muito diferente da de um juiz que precisa decidir se e-books estão abrangidos pela mesma imunidade tributária aplicável a livros.

Dworkin afirma, porém, que não existe essa diferença: a integridade tanto resolveria os casos difíceis como mostraria porque os casos fáceis são fáceis ${ }^{265}$. Pode ser óbvio, por exemplo, que regras de trânsito não podem ser objetadas com base na moralidade - como alguém pode dizer que, "bem interpretada”, a mão de uma rua é o contrário do que indicam placas e regulamentos? - mas esse também é um julgamento moral; a moralidade tem aí um papel negativo ${ }^{266}$, pois pode justificar porque essa não é uma questão moralmente relevante. Podemos dizer, por exemplo, que nenhum direito à igualdade é violado pela determinação da mão de uma rua e que, por isso, não há nenhum argumento moral contra essa regra, o que pressupõe que, contrario sensu, uma violação a um direito de igualdade permitiria que a regra fosse questionada.

Em várias outras situações, nossa resposta a uma questão jurídica será também muito "localizada". Por exemplo, se quero saber a alíquota de um imposto sobre um produto, posso encontrar a resposta diretamente na lei que o instituiu; em resposta a uma consulta sobre isso, nenhum advogado precisará desenvolver todo um argumento sobre o que fundamenta a legitimidade do Estado para instituir este tributo (ou tributos em geral) da forma como o fez. Mas sempre é possível que essa afirmação seja desafiada. Diante de um tribunal ou de uma autoridade administrativa, o advogado do contribuinte poderia argumentar, por hipótese, que a alíquota representa alguma discriminação inconstitucional por ser diferente da alíquota sobre outro produto sem que haja nenhuma justificativa para essa discriminação ou que é confiscatória (violando o art. 150 , IV da Constituição ${ }^{267}$ ), o que dependerá de algum argumento moral, pois não há nenhuma definição convencional sobre o que constitui "confisco". Pode ser que na maioria dos casos nunca cheguemos a esse tipo de questionamento - e que, conscientemente, o advogado ou o juiz sequer o coloquem ${ }^{268}-\mathrm{e}$ a

\footnotetext{
${ }^{265}$ DWORKIN, Law’s Empire, p. 266

${ }^{266}$ DWORKIN, Introduction: Law and Moral, p. 17

${ }^{267}$ Art. 150. Sem prejuízo de outras garantias asseguradas ao contribuinte, é vedado à União, aos Estados, ao Distrito Federal e aos Municípios:

$[\ldots]$

IV - utilizar tributo com efeito de confisco;

268 "I do not mean, to repeat, that judges interpreting statutes must explain, in each case or ever, why the best theories of democracy and fairness support their interpretive methodology. Their training and experience,
} 
resposta sobre a alíquota aplicável seja encontrada em uma simples consulta à legislação, mas como afirma Dworkin,

[...] é como se a ascensão justificatória estivesse sempre disponível [on the cards]: não podemos excluí-la a priori porque nunca sabemos quando uma proposição jurídica que parecia pedestre e mesmo indisputável poderá subitamente ser desafiada por um ataque novo e potencialmente revolucionário vindo de um nível mais alto. ${ }^{269}$

Quão "localizada" será a resposta será definido em cada caso; adotada a integridade como melhor concepção do direito, tal definição será feita em um raciocínio "de dentro para fora" de questões mais concretas para questões mais abstratas, ${ }^{270}$ mas "o ponto absolutamente crucial é que não existe um teste a priori ou no atacado para decidir quando isso será exigido"271. Adotado o convencionalismo, esses saltos em abstração poderiam ser impedidos a priori, mas a razão para essa limitação seria, ainda assim, uma razão moral.

Podemos, então, afirmar, por exemplo, que todos os juízes concordam que os atos do Congresso são fontes do direito, e com isso resolvem muitos casos simples, mas esses juízes "discordam sobre qual é a teoria política que subjaz ao fato de que os atos do Congresso são fontes do direito" ${ }^{272}$. Essas diferentes teorias subjacentes serão baseadas em diferentes teorias sobre a obrigação política e levarão a diferentes teorias de interpretação de leis. ${ }^{273}$ Um juiz convencionalista, prezando pela segurança jurídica, entenderá que é este valor que

supplemented, we might hope, by some academic curiosity, will form their working and largely unexamined methods" (DWORKIN, A New Philosophy for International Law, p. 13)

${ }^{269}$ DWORKIN, In Praise of Theory, p. 54

${ }^{270}$ DWORKIN, In Praise of Theory, p. 68; essa é a diferença entre o que um juiz real pode fazer e o que a alegoria do "juiz Hércules" apresentada por Dworkin representa. O juiz Hércules raciocina "de fora para dentro, pois, antes de decidir um caso simples, já tem toda uma teoria abrangente e articulada sobre o direito e a moralidade" (cf. DWORKIN, Casos Difíceis, especialmente p. 182).

${ }^{271}$ DWORKIN, In Praise of Theory, p. 55

272 PRIEL, The Place of Legitimacy in Jurisprudence, p. 20-21.

${ }^{273}$ Dworkin explica a convergência e as divergências dessas teorias subjacentes através do conceito de "consenso sobreposto" de John Rawls: "[...] even when paradigms are stable, this is rarely because all lawyers regard the law as settled in the same way for the same reason, but in virtue of what John Rawls has called, in a very different context, an overlapping consensus of opinions each of which is based in a somewhat different source. This is conspicuously true about the example of paradigms Hart cites here: legislative supremacy. All lawyers may accept that what a legislature decides is, in principle, law. But they accept this on grounds that vary to some degree from one lawyer to another and that reflect their differing political assumptions and instincts. These differences become evident when lawyers disagree about controversial cases because their differing assumptions about why legislation is central to law generate different theories of statutory interpretation, or different conceptions of how constitutional constraints on legislation should be understood. The same differences are submerged, but not erased, when lawyers agree about what is unquestionably law. They agree on 'settled' law not because they all accept an overarching set of conventional reasons why legislation is ordinarily paramount, but because their divergent reasons for accepting that it is overlap in these large areas of agreement." (DWORKIN, Hart's Posthumous Reply, p. 2123-2124) 
justifica o poder que o Congresso tem e, com isso, entenderá que suas disposições devem ser lidas da forma mais literal possível. Um juiz que adote a concepção do direito como integridade relacionará a legitimidade política a um Estado que fale com "uma só voz" e buscará uma coerência em princípio que poderá ir além das disposições literais de algumas leis. É provável que esses dois juízes concordem sobre como muitos casos devem ser decididos, mas essa concordância será, por assim dizer, apenas superficial, e assim se revelará quando eles divergirem sobre casos difíceis, quando as diferentes teorias do direito subjacentes a suas decisões precisarão ser colocadas em disputa.

Dessa forma, é possível reconstruir as divergências práticas jurídicas como divergências políticas, isto é, divergências sobre o que dá mais legitimidade à coerção estatal e reforça a obrigação de obedecer dos cidadãos. Em um sentido ainda mais abstrato, aceita a igualdade como valor fundante, a divergência será sobre o que poderá realizá-la da melhor forma possível ${ }^{274}$.

Podemos agora retornar à questão com a qual terminei o Capítulo 2: o fato de a teoria do direito de Raz nos levar a um abismo entre o que o direito exige e o que pode ser moralmente justificado permite que a abandonemos em favor de outra teoria que não nos leve a essa situação? Sim, se houver outra teoria disponível que consiga fazer essa ponte, ela deve ser preferida, porque é mais bem-sucedida no propósito que uma teoria do conceito doutrinal do direito deveria ter - o propósito de fazer sentido da utilização reiterada que fazemos do conceito de direito como uma justificação para a coerção.

\subsection{POR QUE NÃO UMA TEORIA SOBRE O CONCEITO SOCIOLÓGICO DE DIREITO?}

Estamos falando até agora de o que deveria ser uma teoria sobre o que Dworkin chama de conceito doutrinal de direito, uma teoria sobre o conceito de direito que utilizamos na prática jurídica para dizer quais são os deveres e direitos que as pessoas têm e para justificar a utilização da coerção. Mas isso é incompatível com a existência de teorias que

\footnotetext{
${ }^{274}$ Como nota Guest, tratando da adoção da integridade como teoria do direito, "The connection between integrity and the ideal of equality is crucial to Dworkin. It is through the single vision of the law, he says, that the state treats its citizens as equals. It is not just that of consistency in dealing which is, as Hart has pointed out, 'compatible with great iniquity,' but incorporates the idea of treating people as equals. Integrity is the principal virtue of legal argument and it is a moral virtue in the political sphere. Thus, legal and moral argument cannot be separated. Legal argument must, according to Dworkin, characteristically refer to the right each person has to be treated as an equal.” (GUEST, Ronald Dworkin, p. 81)
} 
pretendam descrever o que o direito é, de teorias sobre o que Dworkin chama de conceito sociológico de direito?

Raz afirma que para poder sustentar que sua teoria é uma teoria do direito, Dworkin precisaria mostrar que não é possível uma teoria geral sobre a natureza do direito. Dworkin precisaria

estabelecer que o conceito de direito não especifica [single out] uma forma de organização política com características centrais que façam dele um fator crucial na compreensão de todas as sociedades em que ele é encontrado, independentemente de quanto elas difiram em suas ideologias políticas. ${ }^{275}$

Se bem-sucedido, poderia sustentar que não existe nenhuma forma de entender as tarefas da filosofia do direito diferente da sua. Por outro lado, se for possível essa análise sobre a natureza do direito, então a teoria de Dworkin seria falha ao não a oferecer em relação ao direito em geral e ao direito estadunidense em particular. ${ }^{276}$ Como Dworkin nega a possibilidade de uma teoria geral como a pretendida por Raz?

Dworkin argumenta que o conceito de direito é impreciso demais para que a definição de suas fronteiras possa ter alguma importância filosófica ou metodológica. ${ }^{277}$ Pretender avançar a análise de um conceito impreciso sobre essa “área de imprecisão" seria um erro; o que aquele ocupado com o conceito sociológico do direito poderia fazer seria simplesmente descrever tal imprecisão. ${ }^{278}$

O exemplo do conceito de "solteiro" é elucidativo. Trata-se de um conceito que parece não se aplicar a uma criança e que temos dificuldade em dizer se se aplica ou não a um jovem de 18 anos; trata-se de um conceito indeterminado nesse ponto, portanto. Uma "teoria sobre o conceito de solteiro" deveria descrever essa imprecisão e não procurar completá-la com elementos que não podem ser colhidos na prática de seu uso. ${ }^{279}$ A questão sobre os nazistas terem ou não direito seria também uma questão dessa ordem. Também não tem uma resposta certa, depende do propósito de quem está perguntando.

O próprio Raz, ao tratar sobre a explicações teóricas em geral, afirma que a teoria sobre um conceito pode reduzir sua vagueza apenas parcialmente “ou a explicação não será

\footnotetext{
${ }^{275}$ RAZ, Two Views of the Nature of the Theory of Law, p. 88

${ }^{276}$ RAZ, Two Views of the Nature of the Theory of Law, p. 88

${ }^{277}$ DWORKIN, Introduction: Law and Morals, p. 27

${ }^{278}$ DWORKIN, The Concepts of Law, p. 224

${ }^{279}$ DWORKIN, The Concepts of Law, p. 224
} 
fiel ao conceito explicado" 280 . Ocorre que, como Dworkin afirma criticando especificamente Raz, o conceito sociológico de direito é impreciso demais e tem fronteiras muito maleáveis para ter "características essenciais" filosoficamente interessantes. ${ }^{281}$

De fato, podemos nos perguntar em que sentido o que Raz está fazendo poderia ser "sociológico". Afirmar que as regras jurídicas têm um caráter "exclusionário" descreve alguma coisa? Raz não lança mão na construção de seu conceito de métodos que seriam típicos de uma análise sociológica descritiva nesse sentido. Não há pesquisas de opinião, análise de bancos de dados de decisões ou algum outro tipo de análise empírica que sustente suas afirmações sobre o que o direito é.

Nesse ponto, a crítica que Dworkin faz a Hart é pertinente também em relação à abordagem conceitual de Raz:

Hart não empreende nada sequer parecido com a pesquisa que pareceria necessária se ele pretendesse fazer uma afirmação tão radicalmente não-conceitual como a afirmação de que, da forma como as coisas são, todos os juristas em sistema jurídicos comuns - na China antiga, por exemplo, assim como na Polinésia atual - adotaram apenas uma dentre inúmeras concepções de o que faz proposições jurídicas verdadeiras quando elas o são. ${ }^{282}$

Desse modo, a insistência em uma abordagem do direito com pretensões explicativas tão altas demandaria métodos diferentes dos utilizados por Raz e, mesmo assim, pelo que indicam os exemplos de divergências dentro da prática jurídica, estaria fadada ao fracasso, não conseguindo colher os elementos necessários para a elaboração de uma "teoria geral" de qualquer espécie nem explicar em torno de que se dão tais divergências.

É preciso ressalvar que Raz diz expressamente que sua abordagem não é sociológica, pois a sociologia está preocupada com "o contingente e o particular" enquanto a filosofia do direito está preocupada com "o necessário e o universal”, com “as poucas características que todos os sistemas jurídicos necessariamente possuem" 283 e as preocupações teóricas de Raz estariam nessa segunda categoria. Mas o argumento da imprecisão do conceito de direito também se aplica aqui. Afinal, trata-se do argumento de que não há muito de "necessário e universal" a ser descrito pelo teórico em relação ao direito. Em outras palavras, a natureza

${ }^{280}$ RAZ, Two Views of the Nature of the Theory of Law, p. 74

${ }^{281}$ DWORKIN, The Concepts of Law, p. 228

${ }^{282}$ DWORKIN, Hart's Posthumous Reply, p. 2107

${ }^{283}$ RAZ, The Institutional Nature of Law, p. 104 
do direito que Raz procura captar ou não existe ou, se existe, nós não temos como apreendêla. ${ }^{284} \mathrm{O}$ que temos é um conceito de direito, que utilizamos para definir quais são nossos direitos e responsabilidades e que, na nossa prática jurídica, funciona como uma justificação para a coerção ${ }^{285}$ e tem seu uso marcado por extensas controvérsias políticas. No próximo capítulo tratarei justamente de como o erro positivista pode ser visto também como uma confusão conceitual.

${ }^{284}$ Raz afirma que "Concepts are how we conceive aspects of the world, and lie between words and their meanings, in which they are expressed, on the one side, and the nature of things to which they apply, on the other" (RAZ, Can There Be a Theory of Law, p. 19) e que "those who offer explanations of the concept of law usually do mean, as Hart did, to explain the nature of a familiar social institution (ibid., p. 20). Sobre a equivalência entre "natureza" e "conceito" em Raz, ver MURATA, Em Meio à Tempestade..., p. 157

285 "There is a strong practical aspect in Dworkin's conception of law. His view is that we generally use the concept of law in a justicatory way. It is this justicatory purpose that distinguishes the doctrinal concept of law - the one with which we should be concerned in a jurisprudential project - from the 'criterial' concepts that sociologists and historians might deploy." (BUSTAMANTE, T. Revisiting Dworkin's Philosophy of International Law. Canadian Journal of Law and Jurisprudence, v. XXX, n. 2, Agosto 2017p. 271) 


\section{ONDE ERRARAM OS POSITIVISTAS? O ARguMENTO DA CONFUSÃo CONCEITUAL}

Até aqui apresentei os argumentos a favor de uma teoria normativa do direito baseados na importância do direito para o exercício do poder. Argumentei que, quando tomamos consciência de que dizer $o$ que o direito é funciona como uma justificação para a atribuição de direitos subjetivos e obrigações a cidadãos e autoridades, somos levados à construção de uma teoria do direito que possa fazer sentido desse papel justificatório e reforçar uma obrigação de obedecer ao direito.

Contra essa abordagem, está a construção de uma teoria apenas descritiva, sem pretensão de fornecer um conceito cuja invocação possa servir para fundamentar alguma obrigação genuína. É a abordagem positivista. ${ }^{286}$ Como é possível que o positivista sustente esse tipo de teoria? Como, tratando do direito, marcado por tanta controvérsia e com tantas consequências práticas, é possível que insista estar descrevendo de forma politicamente neutra?

Dworkin, a partir de Law's Empire, sugere que essa insistência é derivada de uma confusão conceitual ${ }^{287}$. É dessa confusão que tratarei a seguir. Para isso, apresentarei, inicialmente, a tipologia de conceitos proposta por Dworkin, destacando o que ele entende por "conceito interpretativo". Tratarei, então, de como essa categoria se aplica ao conceito doutrinal de direito e do erro dos positivistas em o entenderem como o que Dworkin chama de "conceito criterial".

\subsection{A TIPOLOGIA DE CONCEITOS DE DWORKIN}

Na tipologia proposta por Dworkin, existiriam três espécies de conceitos: (i) conceitos criteriais, (ii) conceitos naturais e (iii) conceitos interpretativos.

\footnotetext{
${ }^{286}$ Estou chamando de "positivistas" aquelas abordagens que se pretendem não normativas, mas apenas descritivas, como a de Raz. Está excluído o positivismo normativo (ou "politico") das minhas referências ao positivismo, portanto.

${ }^{287} \mathrm{Na}$ introdução de Law's Empire, Dworkin afirma que naquele livro dará ênfase aos “defeitos interpretativos" do positivismo e não aos "fenomenológicos" como tinha feito até então, embora eles digam respeito a "no fundo, as mesmas falhas" (DWORKIN, Law's Empire, p. viii). Dworkin também nega que exista uma diferença substancial entre esses dois grupos de argumento em DWORKIN, The Concepts of Law, p. 233.
} 
Conceitos criteriais são aqueles que "somente podem ser compartilhados quando as pessoas concordam sobre a definição - aproximada ou precisamente - que coloca os critérios para a aplicação correta do termo ou da frase associados a ele" ${ }^{288}$. Desenvolver uma teoria de conceitos criteriais significa, então, "propor uma definição mais precisa dele para um propósito particular" ${ }^{289}$. Podemos pensar em "solteiro" como um exemplo de conceito criterial.

Conceitos naturais são aqueles que têm como referência alguma estrutura física, natural ou biológica. Por exemplo, “tigre”. Os conceitos naturais permitem um tipo de análise que os conceitos criteriais não permitem:

a ciência pode reivindicar ter descoberto a essência verdadeira daqueles [conceitos naturais], na forma de sua organização molecular ou biológica, que não faria nenhum sentido para estes [conceitos criteriais]. ${ }^{290}$

Finalmente, e mais importante, conceitos interpretativos são aqueles que "nos encorajam a refletir e contestar o que alguma prática que construímos requer" ${ }^{291}$. São exemplos desse tipo de conceito conceitos centrais da filosofia política e da moralidade em geral: justiça, liberdade, igualdade, democracia, etc.

É importante ressalvar que essa tipologia é, em grande parte, uma "invenção" de Dworkin, que serve para tornar mais claros seus argumentos. Ela é feita considerando como os conceitos são usados na prática, buscando explicar esse uso, com as diferentes “gramáticas" que existem para cada tipo de conceito ${ }^{292}$. São “ideias de filósofo", no sentido de que não são reconhecidas por quem utiliza os conceitos - é evidente que um biólogo não

\footnotetext{
${ }^{288}$ DWORKIN, Law and Morals. p. 9

${ }^{289}$ No original: "developing a theory of this kind of concept means proposing a more precise definition for some particular purpose" (DWORKIN, Introduction: Law and Morals, p. 9)

${ }^{290}$ DWORKIN, Introduction: Law and Morals, p. 10

${ }^{291}$ DWORKIN, Introduction: Law and Morals, p. 10

292 “[Dworkin] apontou como os ‘jogos de linguagem’ envolvidos em nosso uso de diversos tipos de conceitos variam e como o não reconhecimento dessa variação leva a equívocos filosóficos. Por não percebermos qual é o jogo de linguagem que estamos jogando, acabamos por nos tornar vítimas do ‘enfeitiçamento da linguagem', como diria Wittgenstein. Para este não existe gramática fixa para o uso dos conceitos que nos permita elaborar uma gramática ou conceitografia geral. A linguagem não possui uma estrutura gramatical única, como queriam os positivistas lógicos e o próprio Tractatus de Wittgenstein. Antes o contrário: ao compreendermos o uso de cada conceito, devemos atentar para o fato de que o usamos (e, portanto, atribuímos a ele sentido) segundo jogos de linguagem possivelmente distintos (MACEDO Jr, Do Xadrez à Cortesia, p. 180, notas de rodapé omitidas)
} 
precisa dizer que o conceito de tigre é um "conceito natural" para utilizar o conceito com competência - mas se justificam por seu papel de "fazer sentido da prática"293.

Assim, quando Dworkin diz, por exemplo, que a teoria do direito é interpretativa ele não o está dizendo no sentido trivial de que ela procura apenas explicar o significado de algo, mas no sentido específico que ele dá à atividade de interpretar. Isso parece ser ignorado em parte da crítica feita a Dworkin por Raz, por exemplo quando este afirma que "o único aspecto surpreendente" da afirmação de que a teoria do direito é interpretativa é que ela possa ser considerada "nova e diferente do que muitos filósofos do direito contemporâneos acreditam estar fazendo" 294 . Considerando o que Dworkin chama de interpretação, sua teoria do direito é sim radicalmente diferente do que a de positivistas como Hart e Raz, como explicarei a seguir.

\subsection{CONCEITOS INTERPRETATIVOS}

É um erro ver a afirmação de que o conceito de direito é interpretativo como uma espécie de argumento cabal contra teorias positivistas. Sem que sejam feitas maiores qualificações, a razão está com Raz ao sugerir que todos estão interpretando e não há nada de novo em chamar o conceito de direito de interpretativo. É preciso, portanto, entender o que Dworkin está chamando de interpretação, para sabermos se há algum ganho teórico em afirmar, no sentido por ele proposto, que o direito é um conceito interpretativo.

Dworkin entende a interpretação como, ao lado da ciência, um dos dois grandes domínios da atividade intelectual, abrangendo atividades tão distintas como a interpretação de uma época por um historiador, de um poema por um crítico ou de uma lei por um advogado. ${ }^{295} \mathrm{O}$ que essas atividades teriam em comum para ele seria o fato de que apresentamos nossas conclusões sobre elas em termos de intenções ou propósitos. Falamos das ambições que moldaram uma época, do significado do verso de um poema, do propósito de um artigo em uma lei e assim por diante. ${ }^{296}$

\footnotetext{
${ }^{293}$ Nesse sentido, todos os conceitos seriam interpretativos (DWORKIN, Justice for Hedgehogs, p. 163)

${ }^{294}$ RAZ, Two Views of the Nature of the Theory of Law, p. 47

${ }^{295}$ DWORKIN, Justice for Hedgehogs, p. 123

${ }^{296}$ DWORKIN, Justice for Hedgehogs, p. 125
} 
Uma opção seria entender que essa linguagem de intenções e propósitos se refere às intenções de pessoas específicas - como, no Direito, à “intenção do legislador”. Mas essa não seria uma boa explicação para a interpretação em geral. Pensemos em uma conversa entre duas pessoas. O que guia nossa interpretação sobre o que nosso interlocutor está dizendo? Quando interpretamos o que alguém nos fala em uma conversa, estamos tentando entender o que ele quis dizer, qual foi sua vontade. Nesse caso, a busca pela intenção do interlocutor é uma boa explicação de o que é interpretar. Mas quando pensamos na atividade de um historiador é difícil dizer que suas interpretações têm por objeto a descoberta da vontade de alguém ${ }^{297}$. Se a questão é, por exemplo, o que significou a Revolução Francesa, a resposta não será buscada em suposições sobre o que passava pela cabeça dos franceses no final do século XVIII.

Para superar essa crítica e fornecer uma teoria mais abrangente do que é interpretar, Dworkin sugere que a interpretação deve estar relacionada à atribuição de valores, variando em seus métodos conforme os valores atribuídos ao que se pretende interpretar. Como intérpretes, nós aceitamos uma responsabilidade ${ }^{298}$ de promover aquele valor e é isso que guia nossa interpretação. Esquematicamente ${ }^{299}$ haveria três momentos em uma interpretação: (i) identificação de uma prática social, (ii) atribuição de um conjunto de propósitos àquele gênero ou subgênero e (iii) identificação da melhor realização desse conjunto de propósitos. ${ }^{300}$ Essas três fases correspondem ao que, em Law's Empire, Dworkin chama de estágios (i) pré-interpretativo, "no qual as regras e padrões tomados como provendo o conteúdo provisório da prática são identificados", (ii) interpretativo, "no qual o intérprete estabelece alguma justificação para os principais elementos da prática identificados no estágio pré-interpretativo" e (iii) pós-interpretativo, no qual o intérprete “ajusta seu senso sobre o que a prática 'realmente requer' de modo a servir à justificação que ele aceita no estágio interpretativo".301

\footnotetext{
${ }^{297}$ DWORKIN, Justice for Hedgehogs, p. 129

${ }^{298}$ É esse o sentido de se dizer que o intérprete deve impor um point à prática: "When Dworkin says interpreters must 'impose' a point upon the practice, he must be taken to mean that he is merely requiring that interpreters assume an individual responsibility for their own judgments about the practice's point." (BUSTAMANTE, T. Revisiting the Idea of Protestant Interpretation: Towards Reconciliation between Dworkin and Postema. Federal University of Minas Gerais Research Paper, Maio 2018. p. 10)

${ }^{299}$ Trata-se não de uma descrição de como as coisas se passam, mas de uma reconstrução: "I tried to describe my three-stage analysis of interpretation as a reconstruction, not a piece of phenomenology” (DWORKIN, Response, p. 1067)

${ }^{300}$ DWORKIN, Justice for Hedgehogs, p. 131

${ }^{301}$ DWORKIN, Law's Empire, p. 65-66
} 
O paralelo com o que vimos em relação ao direito já deve estar evidente. A prática jurídica é identificada, a ela é atribuído um propósito como a segurança jurídica ou a integridade e, então, buscam-se formas de realizar esses propósitos. Já ao interpretar o que alguém nos diz em uma conversa buscamos identificar o que o interlocutor está querendo dizer porque o propósito da conversa é justamente a comunicação dessa vontade.

O que há de importante nesse gênero "interpretação", portanto, para que ele se diferencie e esteja ao lado do que chamamos de "ciência" é que, ao interpretar, a resposta sobre o que o objeto da análise significa é sensível à resposta sobre qual é o valor que esse objeto tem ${ }^{302}$, enquanto na ciência os resultados de uma pesquisa não são afetados pelo valor que atribuímos ao objeto daquela pesquisa ${ }^{303}$. Por exemplo, dizer o que o direito é depende parcialmente de dizer o que o direito deve ser, mas dizer o que é o aquecimento global não depende do valor que atribuímos ao meio-ambiente ou ao desenvolvimento econômico. Ou, como Dworkin argumenta em Religion Without God, o fato de que cientistas ambicionem encontrar uma teoria unificadora e consistente na Física, não afasta a possibilidade de que, na verdade, o universo seja "desorganizado" e uma teoria como essa não possa ser encontrada ${ }^{304}$. As ambições dos cientistas não podem mudar os critérios de verdade da ciência.

A interpretação conceitual, por sua vez, é um tipo de interpretação, que se volta a um conceito criado por uma comunidade, incluindo o próprio intérprete. ${ }^{305}$ Os conceitos interpretativos são aqueles conceitos cujo significado é compreendido através da interpretação, nesse sentido de interpretação proposto por Dworkin. Assim,

compartilhamos um conceito interpretativo quando nosso comportamento coletivo utilizando esse conceito é melhor explicado se presumimos que seu uso correto depende da melhor justificação do papel que ele desempenha para nós ${ }^{306}$ (grifei)

Como tenho argumentado até aqui, apresentar o conceito doutrinal de direito como justificação da coerção conectado a um point como a integridade ou a segurança jurídica é

\footnotetext{
${ }^{302}$ DWORKIN, Justice for Hedgehogs, p. 135

${ }^{303}$ DWORKIN, Justice for Hedgehogs, p. 153

${ }^{304}$ DWORKIN, R. Religion Without God. Cambridge: Harvard University Press, 2013, p. 62

${ }^{305}$ DWORKIN, Justice for Hedgehogs, p. 136

${ }^{306}$ DWORKIN, Justice for Hedgehogs, p. 158
} 
uma explicação melhor de como esse conceito funciona para nós. É justamente por isso que ele pode ser qualificado como um conceito interpretativo.

É importante destacar que não há nada fora da prática argumentativa que permita que um conceito seja qualificado como interpretativo ou não. Nenhuma "natureza" dos conceitos determina quando um conceito é de um tipo ou de outro: "para que um conceito seja interpretativo basta que as pessoas convirjam em tratá-lo como interpretativo "307.

Isso significa, por exemplo, que seria possível pensar em uma sociedade hipotética em que todos entendessem que o estado está justificado a utilizar a força unicamente porque se deve obediência às ordens de um soberano escolhido por Deus para governar - supondo que também não houvesse divergência sobre ser aquele soberano o escolhido por Deus. Isto é, não é logicamente impossível pensar em uma sociedade em que o direito (entendido como as ordens desse soberano) funcionasse como um conceito criterial. O próprio Raz dá um exemplo sobre uma situação como essa. Ele diz que "nosso" conceito de direito é estranho a uma teocracia islâmica como o Irã, mas que seria absurdo pensar que o Irã não tem um sistema jurídico. ${ }^{308}$ Isso pode ser verdade, mas não nos compromete a um conceito "neutro" de direito. Pode ser que, no Irã, o conceito doutrinal de direito funcione como um conceito criterial, o que difere de sua utilização em países como os Estados Unidos, o Reino Unido ou o Brasil, em que ele funciona como um conceito interpretativo.

Também é possível que um conceito de um tipo passe a ser um conceito de outro tipo. Essa sociedade hipotética a que me referi - e que talvez possa ser exemplificada por uma teocracia islâmica - poderia mudar sua atitude em relação à autoridade e passar a questionar quais são suas obrigações para além do que dita o soberano. Ou, em um exemplo mais próximo, um conceito criterial como "livro" pode-se tornar interpretativo quando, por fazer parte de algum texto jurídico, um tribunal tenha que decidir o que é um livro e o que não é. ${ }^{309}$

${ }^{307}$ DWORKIN, Introduction: Law and Morals, p. 12.

${ }^{308}$ RAZ, On the Nature of Law, p. 95

${ }^{309} \mathrm{O}$ exemplo do livro é do próprio Dworkin (DWORKIN, Justice for Hedgehogs, p. 165), mas, como já mencionei, essa questão foi enfrentada pelo Supremo Tribunal Federal quando precisou decidir se e-books entravam na imunidade constitucional prevista pelo art. 150, VI, d) da Constituição Federal para livros; naquele caso, o tribunal decidiu que o critério para definir o que era um livro deveria ser "finalístico" e corresponder a "veículo de transmissão de pensamentos", o que abrangeria e-books e os suportes utilizados exclusivamente para fixá-los (RE 330817, Relator: Min. DIAS TOFFOLI, Tribunal Pleno, julgado em 08/03/2017, 
Com isso, quero destacar que a qualificação de um conceito como interpretativo não é uma afirmação a-histórica, descontextualizada ou, de qualquer forma, externa à prática da comunidade onde o conceito é utilizado. A questão, mais uma vez, é como melhor fazer sentido da prática que se interpreta.

Um exemplo mais esclarecedor seja talvez o do conceito de "casamento". Olhando para práticas passadas, alguém poderia afirmar que uma parte necessária do conceito de “casamento" é de "união entre pessoas de sexos diferentes". Hoje alguém ainda pode manter essa posição, mas precisará procurar outras formas de fundamentá-la. Precisará apelar aos valores subjacentes à prática que é o casamento. Descrever as discussões sobre o casamento homoafetivo como discussões sobre como definir mais precisamente um conceito - i.e., descrevê-las como se referindo a um conceito criterial - seria simplesmente não entender o teor da discussão. ${ }^{310}$ Mesmo que alguém insista em oferecer uma descrição de casamento como conceito criterial em uma discussão como essa, essa descrição estará fora de lugar; faltará a essa pessoa a autoconsciência a respeito do que está em discussão no debate em que ela pretende se engajar.

A teoria do direito estaria dominada por esse tipo de confusão, por uma pressuposição de que apenas compartilhamos um conceito quando há um "teste decisivo" para saber o que ele abarca ou não ${ }^{311}$ que impede que se explique adequadamente divergências em torno do conceito de direito semelhantes às divergências que existem em torno do conceito de casamento. Trata-se da confusão positivista de tratar o direito como um conceito criterial.

\subsubsection{CONCEITOS E CONCEPÇÕES}

\footnotetext{
ACÓRDÃO ELETRÔNICO REPERCUSSÃO GERAL - MÉRITO DJe-195 DIVULG 30-08-2017 PUBLIC 31-08-2017)

310 “Dois juristas brasileiros podem discordar sobre o valor de verdade da seguinte proposição: 'os gays têm direito ao casamento, segundo o direito brasileiro'. Alguns poderão afirmar que ela é falsa, pois o casamento é, por convenção, uma relação more uxorio entre pessoas de sexos diferentes. Para embasar tal entendimento, bastaria observar as práticas pretéritas de identificação do que é um casamento para concluir que essa é uma instituição heterossexual. Contudo, se esse fosse o significado de casamento em disputa nos tribunais de diversas jurisdições internacionais nos dias de hoje, seria difícil até mesmo compreender como seria possível ou inteligível essa disputa. Afinal, o objeto mesmo do desacordo se refere ao conceito de casamento. Ele é o centro do desacordo justamente em face de seu caráter valorativo e não puramente convencional. No âmbito das disputas judiciais, o conceito de casamento é um conceito interpretativo, e não um conceito convencional." (MACEDO Jr., O direito em desacordo, p. 20)

${ }^{311}$ DWORKIN, Justice for Hedgehogs, p. 159
} 
Para explicar como se dão as divergências em relação a conceitos interpretativos, Dworkin chama as diferentes posições sobre o que cada conceito interpretativo realmente requer de concepções. Em suas palavras:

No primeiro nível [o do conceito], o acordo se dá entre ideias simples que são incontroversamente empregadas em todas as interpretações; no segundo [o da concepção], a controvérsia latente nessa abstração é identificada e assumida. ${ }^{312}$

Por exemplo, quanto à cortesia, as pessoas podem discordar sobre o que ela significa exatamente e, consequentemente, sobre o que ela requer em diversas situações, mas há certo consenso de que a cortesia é uma questão de respeito. Através das noções de "conceito" e "concepção" podemos descrever a divergência sobre a cortesia em uma comunidade não como um debate sem sentido entre partidários de dois conceitos distintos, mas como uma disputa de diferentes concepções (de diferentes visões sobre o que o respeito realmente requer) sobre um conceito. ${ }^{313}$ É nesse sentido que uma concepção pode ser vista como algo novo e não simplesmente como uma "análise". ${ }^{314}$ É nesse sentido que, como visto, pode-se responder à afirmação de Raz de que Dworkin erra por presumir que a filosofia do direito cria um conceito de direito quando, na verdade, ela apenas explica um conceito que existe independentemente dela. ${ }^{315}$

Os debates sobre uma série de questões morais podem ser descritos como disputas entre diferentes concepções de um conceito. Por exemplo, se admitirmos que o conceito de autoridade é um conceito interpretativo, no sentido visto acima, e que existe uma disputa quanto a qual é seu point, então a análise pretensamente neutra que Raz faz sobre a autoridade perde o sentido e, consequentemente, não poderá figurar na forma como ele conceitua o direito sem que seja acompanhada de uma justificação moral. A autoridade precisaria ser relacionada a algo como um "direito de governar” e suas diferentes concepções às formas de fazer surgir tal direito. ${ }^{316}$

\footnotetext{
312 DWORKIN, Law's Empire, p. 71

${ }^{313}$ DWORKIN, Law's Empire, p. 71

${ }^{314}$ DWORKIN, Justice for Hedgehogs, p. 180

${ }^{315}$ RAZ, Two Views of the Nature of the Theory of Law, p. 84-85

316 "Em termos mais concretos, as diferentes concepções de autoridade legítima pretendem explicar o que significa ter o 'direito de governar'. A justificação normal afirma que tem esse direito a autoridade que for mais sábia que os cidadãos, a ideia de conquista moral defende que a autoridade tem o direito de governar quando permite a ação em concerto, a integridade afirma ter direito de governar a autoridade que trata aos cidadãos com igual consideração e respeito.” (MURATA, Em Meio à Tempestade..., p. 137)
} 
$\mathrm{Na}$ verdade, não é sequer necessário que se identifique incontroversamente um conceito para que possam ser propostas diferentes concepções sobre ele. Basta que se compartilhe um paradigma. Por exemplo, não é preciso que seja delineado um conceito preciso de "justiça" sob o qual todos os conceitos sejam agrupados para que possamos dizer que há desacordos genuínos sobre ela. $\mathrm{O}$ fato de que concordamos com uma afirmação como a de que "seria injusto punir alguém sabidamente inocente por algum crime" já representaria um consenso suficiente para que houvesse divergências genuínas sobre o que a justiça exige. ${ }^{317} \mathrm{O}$ conceito de direito proposto por Dworkin - de justificação para a coerção - é, como visto, apenas um "platô onde a discussão entre as concepções do direito é mais útil"318, podendo ser negado por outros teóricos e juristas sem que isso implique estarem falando de outro conceito.

\subsubsection{ATÉ ONDE PODE IR A INTERPRETAÇÃO DE UM CONCEITO?}

Mas qual é o limite do que pode ser uma concepção de um conceito? Falei sobre como uma concepção pode ser uma novidade criada pelo intérprete. Mas quanto ele pode inovar? Quando ele não estará mais simplesmente oferecendo uma concepção inovadora de um conceito e sim já tratando de algo diverso do conceito que ele pretendia interpretar? Essa é uma questão pela qual passamos lateralmente ao tratar dos sistemas jurídicos injustos (subseção 3.3.2, acima), mais especificamente ao nos perguntarmos até que ponto podemos dizer que alguma norma aparentemente jurídica não faz parte de um sistema jurídico bem interpretado, isto é, ao nos perguntarmos até que ponto podemos salvar um sistema jurídico de ser qualificado como injusto ao oferecer uma concepção dele que retire sua injustiça.

Como visto acima, Dworkin distingue três momentos em uma interpretação: (i) identificação de uma prática social, (ii) atribuição de um conjunto de propósitos àquele gênero ou subgênero e (iii) identificação da melhor realização desse conjunto de propósitos em uma ocasião em particular. ${ }^{319} \mathrm{~A}$ identificação dessa prática social seria a parte menos controversa, exigindo um grau maior de consenso ${ }^{320}$ sobre afirmações como "o direito está relacionado ao que está escrito em leis aprovadas pelo Congresso" e o segundo momento

\footnotetext{
${ }^{317}$ DWORKIN, Justice for Hedgehogs, p. 160-161

${ }^{318}$ DWORKIN, Law's Empire, p. 190

${ }^{319}$ DWORKIN, Justice for Hedgehogs, p. 131

${ }^{320}$ DWORKIN, Justice for Hedgehogs, p. 131; também DWORKIN, Law's Empire, p. 65-66, onde Dworkin a chama de "pré interpretativa".
} 
também exigiria uma certa convergência ${ }^{321}$, sobre uma afirmação como a de que "o direito exige uma ação estatal coerente em princípio" ou que "o direito visa dar previsibilidade aos cidadãos". A questão diz respeito, então, ao valor oferecido como justificação nesse segundo momento (integridade, segurança jurídica, etc.) e a como realizar tal valor em casos concretos. Por que não dizer que ao defender a integridade como melhor concepção do direito, Dworkin está tratando de algo que já não é mais direito? Por que não dizer que ao afirmar que a pena de morte é contrária ao direito americano, Dworkin está falando do que ele gostaria que o direito americano fosse e não do que o direito americano é?

A resposta é que ao oferecer uma concepção o teórico deve atender não só a uma dimensão de moralidade política, mas também a uma dimensão de adequação [fit] e que esta é compatível com a afirmação de que a pena de morte é inconstitucional. A adequação da interpretação proposta tem que ser suficiente "para que o intérprete possa se ver como interpretando aquela prática e não inventando uma nova" ${ }^{\text {322 }}$. Por exemplo, por mais que alguém aceite alguma teoria de justiça distributiva radical - por exemplo a proposta por John Rawls - como correta, não é possível dizer que o que dá a justificação para a forma como o direito brasileiro é praticado é a aplicação dessa teoria. Leis, juízes e autoridades repetidamente reconhecem o direito de propriedade de forma completamente indiferente a esse tipo de prescrição distributiva. Assim, uma justificação como essa não passaria pelo teste inicial de o que é uma teoria competente sobre o direito brasileiro.

Por outro lado, considerando apenas essa dimensão de adequação, seria possível chegar a teorias do direito igualmente absurdas. Por exemplo, dizer que o propósito principal do direito como é praticado em vários lugares é enriquecer advogados. Haveria vários elementos na prática brasileira, por exemplo, que indicariam isso - em regra, é obrigatória a representação processual por advogado, há uma série de recursos e instâncias, o Estado se nega reiteradamente a fornecer serviços e conceder benefícios que ele concede judicialmente, é garantido o pagamento de honorários sucumbenciais mesmo que já tenham sido pagos honorários contratuais, etc. -, mas essa justificação não pode ser sustentada por um argumento de moralidade política, porque não expressa nenhum valor suficientemente 
importante para justificar toda a força que o direito tem. ${ }^{323}$ Daí serem importantes essas duas dimensões na interpretação, a da adequação e a da moralidade política.

Voltando ao caso do direito injusto, a pergunta será, naquele caso, se é possível a construção de alguma justificação para aquele direito - se há alguma justificação que se adeque a ele - que não coloque a injustiça em seu centro. Se não for possível construir essa justificação e se só conseguirmos construir alguma justificação tão imoral como “o propósito do direito é eliminar uma raça impura", então não haverá uma obrigação de obedecê-lo.

Em casos mais cotidianos, isso significa que um juiz não poderá fazer do direito o que ele gostaria que ele fosse. Há uma série de constrangimentos de adequação que se impõem a ele. Como afirma Dworkin,

[q]ualquer teoria plausível desqualificaria uma interpretação de nosso direito que negasse completamente a competência ou a supremacia legislativas ou que defendesse um princípio geral de direito privado requerendo que os ricos compartilhem sua riqueza com os pobres. Esse limite [threshold] elimina interpretações que de outra forma outros juízes prefeririam, de modo que os fatos brutos da história jurídica limitarão, desse modo, o papel que as convicções pessoais de justiça de qualquer juiz podem desempenhar em suas decisões. ${ }^{324}$

Assim, ao afirmar que a pena de morte é contrária ao direito americano, fundamentando-se, por exemplo, em direitos relacionados à dignidade previstos na Constituição Americana e que se expressam em decisões judiciais em diversas áreas do direito, Dworkin pode reivindicar que não está inventando um novo direito americano, mas oferecendo uma interpretação melhor sobre ele, o que provavelmente seria diferente de uma defesa de que a pena de prisão também é inconstitucional.

É preciso ressalvar que ao falar em dimensões da interpretação, Dworkin não está sugerindo que a adequação seja um "teste mecânico". Na verdade, a definição dessas duas dimensões é apenas um “dispositivo analítico para ajudar a entender a lógica da interpretação e as diferentes formas pelas quais ela pode ser desafiada" ${ }^{325}$. Tem apenas uma função "heurística" ${ }^{326}$. Isto é, de forma coerente ao que temos visto, o teste da adequação também é parte de um argumento de moralidade política e será influenciado por argumentos dessa

\footnotetext{
${ }^{323}$ DWORKIN, Introduction: Law and Morals, p. 15

${ }^{324}$ DWORKIN, Law's Empire, p. 255

${ }^{325}$ DWORKIN, Introduction: Law and Morals, p. 15

${ }^{326}$ DWORKIN, Reply in Dworkin and His Critics, p. 381-382
} 
ordem. ${ }^{327}$

\subsection{QUE TIPO DE CONCEITO É O CONCEITO DE DIREITO?}

Dworkin defende que o direito deve ser compreendido como um conceito interpretativo e que o positivismo o compreenderia mal ao tentar descrevê-lo sem levar isso em consideração ${ }^{328}$. Isso pode ser visto, como uma reformulação do argumento original de Dworkin sobre o "ferrão semântico" 329 . Reformulado, seu argumento seria de que a “infecção" dos positivistas pelo ferrão semântico é a pressuposição de que todos os conceitos de direito, inclusive o conceito doutrinal, dependem de uma prática convergente que define o conceito ou através de critérios compartilhados de aplicação (i.e., como um conceito criterial) ou relacionando-o a alguma estrutura natural (i.e., como um conceito natural). ${ }^{330}$

Antes da construção de uma teoria sobre o que faz com que proposições jurídicas sejam verdadeiras, o teórico do direito passaria, mesmo que inconscientemente, pelo que Dworkin chama de "fase semântica", na qual responderia que tipo de conceito o direito é. Entendendo que se trata de um conceito interpretativo, ele passaria à "fase teórica [jurisprudential]”, em que atribuiria um valor - ou point - à prática jurídica - para, então, a partir desse point, finalmente definir o que faz com que uma proposição jurídica seja verdadeira ou não. ${ }^{331}$ Como se pode ver, exceto pela referência à categoria de "conceito interpretativo" não há nesse caminho nenhuma novidade em relação aos argumentos vistos até aqui. Essa categoria, porém, destaca onde estaria o erro positivista. Ele estaria na primeira dessas fases, ao tomar - geralmente de forma inconsciente - o direito como um conceito criterial e procurar explicá-lo nesses termos. Esse longo argumento de Dworkin é apresentado como uma espécie de genealogia do erro positivista.

Mas o que significa dizer que o direito não pode ser explicado como um conceito criterial? Dworkin parece pressupor que a existência de divergência em relação a um conceito, ou pelo menos em relação a "casos centrais" de aplicação desse conceito, já

\footnotetext{
${ }^{327}$ DWORKIN, Introduction: Law and Morals, p. 15-16

${ }^{328}$ DWORKIN, Introduction: Law and Morals, p. 12

${ }^{329} \mathrm{O}$ argumento original era de que são vítimas do ferrão semântico aqueles que "think we can argue sensibly with one another if, but only if, we all accept and follow the same criteria for deciding when our sound" (DWORKIN, Law's Empire, p. 45)

${ }^{330}$ DWORKIN, The Concepts of Law, p. 225-226

${ }^{331}$ DWORKIN, Introduction: Law and Morals, p. 9-13
} 
implicaria a inadequação de uma "gramática criterial” para explicá-lo. ${ }^{332}$ Raz oferece, entretanto, argumentos em defesa da possibilidade dessas divergências.

Tratarei, a seguir, do tipo de divergência que pode existir em torno de um conceito criterial, para, em seguida, argumentar que o conceito de direito proposto por Raz pode ser assim classificado. Argumentarei que mesmo que possa haver divergências genuínas em relação a conceitos criteriais, não são desse tipo as divergências que se alastram pela prática jurídica, melhor explicadas pela compreensão do direito como um conceito interpretativo.

\subsubsection{DIVERGÊNCIAS E CONCEITOS CRITERIAIS}

Como visto, Dworkin define conceitos criteriais como aqueles que "somente podem ser compartilhados quando as pessoas concordam sobre a definição - aproximada ou precisamente - que coloca os critérios para a aplicação correta do termo ou da frase associados a ele"333. Não há uma "essência", como existe em relação a um conceito natural (dada pelo DNA, por exemplo) a ser descoberta pelo cientista ${ }^{334}$, de modo que a verdade das proposições sobre os conceitos criteriais só pode ser consequência da forma como ele efetivamente é usado.

Raz, por sua vez, afirma que uma "explicação criterial” de um conceito (i) coloca uma regra especificando as condições para o uso correto do conceito e (ii) é uma explicação verdadeira em virtude do fato de que é uma afirmação correta das condições para o uso correto do conceito por aqueles que efetivamente usam o conceito. ${ }^{335}$ Ambos estão falando do mesmo tipo de conceito, que será explicado pela descrição dos critérios que regem seu uso. Mas Raz admite que podem haver divergências genuínas em torno de conceitos criteriais. Como isso é possível?

\footnotetext{
332 "Dworkin's conclusion that certain concepts, the concept of law among them, cannot be given a criterial explanation rests on the claim that the application of criterially explained concepts cannot be subject to dispute regarding what he calls 'pivotal cases'. Therefore, where, as in the case of the law, the application of a concept can be disputed in pivotal cases, the concept is not susceptible to criterial explanation." (RAZ, Two Views of the Nature of the Theory of Law, p. 60)

${ }^{333}$ No original: "[...] only when they agree on a definition - rough or precise - that sets out the criteria for the correct application of the associated term or phrase" p. 9).

${ }^{334}$ DWORKIN, Introduction: Law and Morals, p. 10

${ }^{335}$ RAZ, Two Views of the Nature of the Theory of Law, p. 60
} 
Em primeiro lugar, Raz afirma que os critérios para a utilização de um conceito criterial não precisam estar completamente especificados para cada pessoa que utiliza esse conceito - contra o que ele chama de "abordagem individualista". O importante seria saber quais são os critérios em que aquela comunidade linguística geralmente se baseia para usar aquela palavra. Cada pessoa pode estar parcialmente ou totalmente errada sobre quais são eles e é possível, inclusive, que tenha conhecimento deles, mas não saiba explicá-los de forma clara.

Por exemplo, se estamos preocupados com descrever o conceito de "autoridade" não iremos buscar o que as pessoas acham que é estar sujeito a uma autoridade, mas devemos buscar efetivamente o que significa estar sujeito a uma autoridade. Várias pessoas podem usar esse conceito de forma parcialmente equivocada, não percebendo, por exemplo, que ele envolve a emissão de razões exclusionárias. ${ }^{336}$

Em segundo lugar, mesmo que alguém tenha muita clareza sobre os critérios que regem a utilização de um conceito, é possível que esses critérios sejam complexos e se relacionem a outros conceitos de modo que haja erros em sua aplicação. ${ }^{337}$

Seriam possíveis, assim, as divergências em relação a conceitos criteriais. Raz argumenta, ainda, que elas seriam "eticamente significativas", pois precisamos de conceitos para criticar ou rejeitar outros conceitos, o que torna importante esclarecê-los. ${ }^{338}$ Mas é esse tipo de divergência que encontramos ao redor do conceito doutrinal de direito? Acredito que não, como argumentarei a seguir.

\subsubsection{O DIREITO COMO CONCEITO INTERPRETATIVO}

\footnotetext{
336 "the service conception is an account of authority, which includes an explanation of what it is to have authority, to be subject to authority, when one has authority or is subject to it, and like questions. The account is not about what people think it is like to have authority or to be subject to it, but of what it is to have it or be subject to it. It is compatible with claims that people have different beliefs on these matters, though it follows from the account that theirs are mistaken beliefs. Does it follow that they are guilty of a conceptual confusion? Worse, does it follow that they do not know their own language? Of course not. If they have false beliefs about authority (not merely about the powers of people who actually have authority) then they have the concept of authority, they have some understanding of what it involves. But their understanding is partial, and in part incorrect. Our understanding of concepts usually is. It leaves plenty of room for mistakes and disagreements" (RAZ, The Problem of Authority, p. 129)

${ }^{337}$ RAZ, Two Views of the Nature of the Theory of Law, p.64-67

${ }^{338}$ RAZ, Two Views of the Nature of the Theory of Law, p.70
} 
Como já vimos no capítulo 2, Raz nega que sua abordagem de autoridade, e consequentemente do direito, seja simplesmente descritiva ou linguística ${ }^{339}$ - ela não permite uma simples explicação "baseada na substitutividade" 340 . Ele afirma que sua teoria é normativa-explanatória. Normativa porque "admite que não se conforma necessariamente às noções de todas as pessoas em todos os seus detalhes" e explanatória porque "seleciona características importantes das concepções de autoridade das pessoas" ${ }^{341}$.

É preciso ter cautela, contudo, com o que se quer dizer com "normativo". Raz não quer dizer normativo no sentido de prescrever razões para a ação, estar baseado em valores ou ser, de qualquer forma, moral, como fica claro quando ele fala sobre sua teoria do direito:

[...] é ilusório ver a tese e o argumento apresentados aqui como morais. O argumento é, de fato, avaliativo, mas no sentido em que qualquer boa teoria da sociedade é baseada em considerações avaliativas já que o sucesso dessas teorias está em destacar estruturas e processos sociais importantes, e todo julgamento de importância é avaliativo. ${ }^{342}$

A "importância moral" das estruturas e processos sociais descritos pela teoria é relevante para determinar se eles serão ou não destacados. Por exemplo, é importante moralmente que o direito pretenda emitir razões exclusionárias. Mas destacar essas estruturas e processos não significa dizer que eles são justificados. Como afirma Waluchow, "alguém pode ver relevância moral sem comprometer-se moralmente"343. Afirmar que o direito pretende emitir razões exclusionárias não significa que elas realmente tenham essa força moral.

Assim, não obstante esse caráter avaliativo da teoria do direito, ela ainda estaria muito limitada ao "escolher" o conceito mais adequado de direito:

Isso [o conceito de direito] é parte da forma como elas [as pessoas comuns] "conceituam" a realidade social. Mas a cultura e a tradição das quais o conceito é parte não lhe fornecem

\footnotetext{
${ }^{339}$ Raz diz que uma abordagem linguística do direito só pode existir a partir da pressuposição de que "the use of 'law' in all contexts but one is analogical or metaphorical or in some other way parasitical on its core meaning as displayed in its use in one type of context, and that that core meaning is the one the legal philosopher has at the centre of his inquiry" e que essa pressuposição estaria errada. (RAZ, J. The Problem about the Nature of Law. In: Ethics in the Public Domain: Essays in the Morality of Law and Politics. Oxford: Clarendon Press, 1995, p. 196)

${ }^{340}$ RAZ, The Morality of Freedom, p. 66.

${ }^{341}$ RAZ, The Morality of Freedom, p. 65-66

${ }^{342}$ RAZ, Authority, Law and Morality, p. 235

${ }^{343}$ WALUCHOW, Inclusive Legal Positivism, p. 23
} 
nem contornos precisamente definidos nem um foco claramente identificável. [...] Várias, e por vezes contraditórias, ideias são apresentadas neles. Cabe à teoria do direito escolher entre aquelas que são centrais e significativas para a forma como o conceito atua no entendimento das pessoas sobre a sociedade, elaborá-las e explicá-las. [...] Não estamos livres para escolher qualquer conceito útil [fruitful]. É uma grande tarefa da teoria do direito melhorar nossa compreensão da sociedade ao nos ajudar a entender como as pessoas se entendem. ${ }^{344}$

Este ponto é fundamental. Certamente não estamos livres para escolher qualquer "conceito útil" de direito. Mas por que não reconhecer as divergências que existem na prática jurídica como divergências que podem ser remetidas a divergências de moralidade política?

Voltando ao exemplo do casamento, mas agora pensando especificamente na discussão sobre o casamento homoafetivo no direito brasileiro, temos no Código Civil uma referência expressa a que o casamento ocorre quando "o homem e a mulher" manifestam sua vontade de $\operatorname{casar}^{345}$, na Constituição brasileira uma referência expressa à "união estável entre o homem e a mulher como entidade familiar" ${ }^{346}$ e nenhuma referência sobre a possibilidade de união entre pessoas do mesmo gênero. Mesmo assim, levantou-se o argumento - ao final, vencedor - de que o direito brasileiro garantia o direito ao casamento a pessoas do mesmo gênero. Um argumento contrário, dentre outros possíveis, é que não era possível o reconhecimento desse direito porque ele "não fazia parte" do direito brasileiro.

Essa divergência poderia ser descrita como uma divergência entre aqueles que afirmam que o direito inclui alguns direitos básicos de autonomia e de igualdade necessários a tornar o poder estatal legítimo, de um lado, e, de outro, aqueles que afirmam que o ideal (moral) do Estado de Direito exige que os tribunais ajam com a maior deferência possível à letra da lei. Por que não descrever essa divergência como uma divergência moral sobre o

\footnotetext{
${ }^{344}$ No original: "It is part of the way they 'conceptualize' social reality. But the culture and tradition of which the concept is a part provide it with neither sharply defined contours nor a clearly identifiable focus. Various, sometimes conflicting, ideas are displayed in them. It falls to legal theory to pick on those which are central and significant to the way the concept plays its role in people's understanding of society, to elaborate and explain them. [...] We are not free to pick on any fruitful concepts. It is a major task of legal theory to advance our understanding of society by helping us understand how people understand themselves." (RAZ, The Morality of Freedom, p. 237)

${ }^{345}$ Art. 1.514. O casamento se realiza no momento em que o homem e a mulher manifestam, perante o juiz, a sua vontade de estabelecer vínculo conjugal, e o juiz os declara casados.

${ }^{346}$ Art. 226. A família, base da sociedade, tem especial proteção do Estado.

$[\ldots]$

$\S 3^{\circ}$ Para efeito da proteção do Estado, é reconhecida a união estável entre o homem e a mulher como entidade familiar, devendo a lei facilitar sua conversão em casamento.
} 
que é o direito ao invés de afirmar que os defensores do reconhecimento do casamento homoafetivo estavam, diante da complexidade do conceito de direito, simplesmente confusos ou argumentando de má-fé?

Não deveríamos tratar a divergência como uma divergência moral se pensamos o direito como um conceito criterial e a teoria do direito como um empreendimento que tem por objetivo esclarecer nossos critérios para compreendê-lo. Como visto, a compreensão do conceito de direito como um conceito criterial não implica a impossibilidade de existência de divergência, mesmo entre participantes que usam o conceito com competência, mas a descrição dessas divergências como divergências reportáveis a questões de moralidade política não estará disponível. Assim, poderíamos até utilizar razões de moralidade para defender uma ou outra decisão pelo STF no caso da união homoafetiva, mas seria fruto de uma “confusão conceitual” afirmar que essas razões eram jurídicas.

A afirmação dessa confusão não depende, para Raz, de nenhum argumento moral. A abordagem raziana é pretensamente neutra e tem por objetivo "explicar a natureza de instituições sociais, o que não é nem uma questão de uso linguístico, nem uma questão de qual uso linguístico seria, se prevalecesse, moralmente melhor" ${ }^{347}$ (grifo meu). Pode ser que o não reconhecimento do casamento homoafetivo torne o direito brasileiro menos legítimo, mas isso não deve ter nenhuma influência na discussão sobre se ele o reconhece ou não.

Isso tudo mudaria se Raz admitisse que existem conceitos interpretativos e que o direito é um conceito desse tipo? Penso que sim, e que por isso podemos dizer que ele vê o direito como um conceito criterial no sentido proposto por Dworkin ${ }^{348}$ e que o argumento de Dworkin sobre o direito ser um conceito interpretativo, se correto, tornaria falsa a teoria do direito de Raz.

${ }^{347}$ RAZ, J. The Argument from Justice, or How Not to Reply to Legal Positivism. In: The Authority of Law. 2nd Edition. ed. Oxford: Oxford University Press, 2009, p. 333

${ }^{348}$ Raz afirma que "In providing an explanation of the concept of law, legal philosophers aim to improve our understanding of the law-that-is: theirs are interpretive explanations", mas fica claro que ele não está falando em "interpretação" no mesmo sentido de Dworkin, quando ele afirma que "every explanation that improves the understanding of a phenomenon with a meaning, or a content, is an interpretation, for interpretation is an explanation, or display, of the meaning of what is explained", concluindo, por fim, que "Interpretive explanations can be criterial explanations" (RAZ, Two Views of the Nature of the Theory of Law, p. 80) 
O conceito de direito é interpretativo porque, como vimos, ele está "integrado a uma prática que pressupõe que proposições jurídicas têm implicações para o exercício do poder" ${ }^{349}$, isto é, uma prática em que se utiliza o conceito de direito como uma justificativa para o uso da coerção e, por isso, as divergências sobre esse conceito nos remetem ao que pode dar essa justificação - a algum valor, como a integridade ou a segurança jurídica. Negar tal relação entre justificação e identificação do direito nos levaria a teorias apenas sobre os fundamentos do direito, com os problemas já examinados na Seção 3.1. Isto é, a teorias que são incapazes de construir um conceito que tenha qualquer relevância na forma como nós cidadãos e autoridades - devemos agir, mesmo sendo, na prática, o conceito de direito utilizado com tal finalidade.

Aqui, podemos retomar o argumento sobre a distinção entre um conceito doutrinal e um conceito sociológico de direito e sobre a imprecisão deste último. Se estamos tratando do conceito doutrinal, a forma como ele funciona na nossa prática jurídica afasta a possibilidade de sua caracterização como um conceito criterial. Se estamos tratando do conceito sociológico, é possível uma descrição criterial, mas a imprecisão desse conceito não permite que se crie uma "teoria geral" sobre ele com o nível de detalhamento que pretende Raz. Não é possível dizer que o conceito é preciso ao ponto de que a única forma correta de o compreender seja como um conjunto de diretivas emitidas com a finalidade de excluir as razões para a não conformidade.

Dworkin acusa Raz de não distinguir entre o conceito doutrinal e o conceito sociológico de direito e de pressupor que ambos os conceitos são do mesmo tipo e devem ser explorados filosoficamente da mesma maneira. ${ }^{350}$ Isto é, de tratar ambos os conceitos como conceitos criteriais. Toda essa tipologia conceitual proposta por Dworkin serve para deixar claro justamente isso, mostrando como teorias positivistas como a raziana falham ao entender mal como o conceito de direito funciona.

\footnotetext{
${ }^{349}$ DWORKIN, Introduction: Law and Morals, p. 19

${ }^{350}$ DWORKIN, The Concepts of Law, p. 228
} 


\section{O DIREITO COMO PARTE DA MORAL E O FIM DA TEORIA DO DIREITO}

Em Law’s Empire, após apresentar sua sugestão de um conceito de direito como justificação da coerção - ao redor do qual se formam suas diferentes concepções -, Dworkin afirma que esse conceito "mostra o velho debate sobre direito e moralidade sob uma nova luz" ${ }^{351}$. Depois, em Justice in Robes ele reformula sua tese, com a sugestão aparentemente extravagante de que não é que a moralidade componha uma parte do direito ou que com ele se relacione, mas que $o$ direito é parte da moralidade. ${ }^{352}$

Essa ideia é retomada em Justice for Hedgehogs, onde Dworkin afirma que errou ao "presumir que o direito e a moral são dois sistemas diferentes de normas e que a questão crucial é como eles interagem", pois

uma vez que tomemos o direito e a moralidade como compondo sistemas separados de normas, não há um referencial neutro de onde as conexões entre esses dois sistemas pudessem ser apreciadas ${ }^{353}$.

Isto é, não haveria uma forma de decidir se a relação entre direito e moral é uma questão jurídica ou se é uma questão moral, o que seria a explicação para a ideia positivista “surpreendente" de que a questão não é nem jurídica nem moral, mas conceitual ${ }^{354}$, a ser resolvida com a busca da essência ou natureza relacionadas a esse conceito.

O argumento desenvolvido nos capítulos anteriores já dava indicações dessa conclusão, que pode, afinal, não ser tão extravagante assim. Se estamos preocupados em oferecer um conceito de direito que possa figurar em proposições sobre o que devemos fazer e fazemos isso procurando um conceito de direito que seja capaz de justificar a coerção pelo Estado, então dizer que o direito tem alguma espécie de "normatividade" que não seja uma normatividade moral parece perder sentido. Mesmo em Raz, vimos que o que ele busca com sua teoria do direito é saber como o direito pretende modificar a moralidade, de modo que "nós não podemos conceber o direito como um ponto de vista normativamente válido que contraste com a moralidade" $" 355$.

\footnotetext{
${ }^{351}$ DWORKIN, Law's Empire, p. 98

${ }^{352}$ DWORKIN, Introduction- Law and Morals, p. 34

${ }^{353}$ DWORKIN, Justice for Hedgehogs, p. 402-403

${ }^{354}$ DWORKIN, ibid.

${ }^{355}$ RAZ, Incorporation by Law, p. 6
} 
Um juiz, por exemplo, ao ser colocado diante de um caso difícil não irá analisar o que ele "deve fazer juridicamente" e considerar, eventualmente, que isso tenha alguma relação com a moral. Ele deve simplesmente decidir o que ele deve fazer, o que é uma questão moral ${ }^{356}$. Isso tanto para Raz quanto para Dworkin. Se o direito é em alguma medida legítimo, então ele terá alguma obrigação de obedecê-lo, mas essa obrigação será também moral. Mais uma vez, isso não quer dizer que qualquer lei injusta (contrária à moralidade) deixe de ser direito, mas que, quando há um dever de obedecer e aplicar essa lei injusta esse dever virá de uma razão moral, ou, dito de outra forma, que a moralidade será modificada por essa lei.

Saber até onde nos leva essa conclusão sobre o direito ser parte da moral é outra questão. Raz diz que se é possível dizer que uma comunidade não é governada pelo direito, então logicamente deve ser possível diferenciar o que é direito e o que não é ${ }^{357} \mathrm{e}$, de fato, oferecer essa diferenciação tem sido uma das principais tarefas que a filosofia do direito avoca para $\mathrm{si}^{358}$. Se consideramos, entretanto, que o direito é parte da moral, ainda temos alguma razão para nos perguntarmos o que o direito é? Teríamos ainda alguma razão para identificar critérios sobre quais são os fundamentos do direito no sentido visto no Capítulo 3 , isto é, teríamos alguma razão para nos preocuparmos com os critérios de verdade de proposições jurídicas?

Uma resposta negativa a essas questões pode parecer natural e teria como consequência que nossa preocupação dissesse respeito, na verdade, apenas ao que cidadãos, autoridades e juízes devem fazer. A pergunta sobre "se considerações morais figuram ou não entre as condições de verdade do direito e, se sim, como" 359 não faria sentido. Isso não significa - pelo menos a priori - que autoridades e cidadãos não devam se guiar pelo que consta em leis, decretos e decisões judiciais. Mas significa que não ganhamos nada em discutir se "faz parte do direito" uma proposição retirada de uma analogia com um texto legal, por exemplo. Para retomar um exemplo, não ganhamos nada em perguntar se o

\footnotetext{
356 "So when a judge faces a question about how to interpret a statute or a clause in the Constitution, or when she has to figure out the bearing of a line of precedents on a dispute in front of her, the question she faces is a moral question; it doesn't just involve moral elements, it is itself a moral question" (WALDRON, J. Jurisprudence for Hedgehogs. New York University Public Law and Legal Theory Working Papers, Paper 417, 2013, p. 7)

${ }^{357}$ RAZ, Incorporation by Law, p. 15-16

358 PRIEL, D. The Boundaries of Law and the Purpose of Legal Philosophy. Law and Philosophy, 2008, p. 2.

${ }^{359} \mathrm{Na}$ introdução de Justice in Robes, Dworkin dizia que essa seria a principal questão em relação ao conceito doutrinal de direito. (DWORKIN, Introduction: Law and Morals, p. 5)
} 
casamento homoafetivo é ou não reconhecido pelo direito brasileiro. Melhor seria perguntar diretamente se o juiz e as autoridades têm, tudo considerado, uma obrigação de reconhecer essa união como um casamento atribuindo as mesmas consequências que um casamento entre um homem e uma mulher teria (regime de bens, direito a pensão, etc.).

Essa resposta negativa é dada por Scott Hershovitz em The End of Jurisprudence, texto em que ele pretende colocar fim ao debate Hart-Dworkin negando aquele que ele identifica ser o pressuposto subjacente a tal debate: a existência de um domínio de normatividade (ou quase-normatividade) estritamente jurídico.

A seguir, (5.1) apresentarei mais detalhadamente o argumento de Hershovitz para, em seguida, (5.2) criticá-lo, defendendo a importância de se identificar o que é especificamente o conteúdo do direito e não apenas o que é moralmente exigido.

Esse argumento de Hershovitz pode parecer uma decorrência natural do que temos visto até aqui. Mesmo assim, acredito que representa um grave equívoco, ao desconsiderar que o direito é defendido por Dworkin como uma forma especialmente valiosa, porque especialmente legítima, de organização social. Assim, entender e enfrentar o argumento de Hershovitz servirá para evitar confusões e deixar mais clara a importância das conclusões que tracei nos capítulos anteriores, destacando o papel justificatório que a identificação do direito deve ter e a preocupação com a legitimidade da coerção estatal que deve acompanhála.

Por fim, apresentarei (5.3) a interpretação que entendo ser a correta da tese de Dworkin de que o direito é parte da moral, contrária à tese de Hershovitz, e que consequências ela pode ter. Esse último ponto também serve para esclarecer até onde vai a divergência entre Dworkin e Raz, já que este também nega que exista um domínio de normatividade especificamente jurídico que se contraponha à moralidade.

\subsection{O FIM DA TEORIA DO DIREITO}

Em The End of Jurisprudence, Scott Hershovitz afirma que por mais de quarenta anos, a teoria do direito tem sido dominada pelo "debate Hart-Dworkin", com, de um lado, Hart e seus herdeiros, como Raz, defendendo que o conteúdo do direito é determinado por 
fatos sociais e, de outro, Dworkin e seus seguidores defendendo que "fatos morais" também têm influência na determinação do conteúdo do direito. ${ }^{360}$

Como já adiantei, o argumento de Hershovitz é que esse debate está mal direcionado, pois pressupõe um domínio especificamente jurídico de normatividade, ou quasenormatividade, que não existe. ${ }^{361} \mathrm{Um}$ domínio de normatividade especificamente jurídico existiria para aqueles que entendem que nossas práticas jurídicas geram um domínio separado de outros domínios de normatividade, como a moralidade e a prudência. Um domínio de quase-normatividade existiria para aqueles que entendem que o que o direito exige, através de noções normativas como obrigação e direito subjetivo, apenas precisa pretender ser normativo e pode, na verdade, não sê-lo. É nesse sentido que se fala que "do ponto de vista do direito" algo é permitido ou proibido ${ }^{362}$ e é esse domínio que se poderia dizer pressuposto por Raz, ao tratar como "ponto de vista relevante" de sua teoria o ponto de vista "do direito" 363 e procurar descrever o que o direito reivindica.

A compreensão de que as práticas jurídicas implicam algumas consequências especificamente jurídicas, criando esse domínio específico de normatividade ou quasenormatividade, seria "o vidro que faz a garrafa" onde estão presos os participantes do debate Hart-Dworkin. ${ }^{364}$

Para construir seu argumento, Hershovitz trata de algumas práticas, com nível crescente de complexidade, em que também lidamos com regras. Especificamente, ele trata da hipótese de uma casa de aluguel onde há uma placa com regras a serem seguidas ${ }^{365}$, da prática de fazer promessas ${ }^{366} \mathrm{e}$, pretendendo tratar de um prática em que mais do que regras esparsas há um sistema de regras institucionalizado, do jogo de xadrez, referindo-se às regras que são expedidas pela Federação Mundial de Xadrez ${ }^{367}$. A lição a se tirar de cada um desses exemplos é, segundo ele, que, embora em todos eles tratemos da aplicação e interpretação de regras, não pressupomos que correspondam, cada um, a um domínio específico de

\footnotetext{
${ }^{360}$ HERSHOVITZ, The End of Jurisprudence, p. 1162

${ }^{361}$ HERSHOVITZ, The End of Jurisprudence, p. 1192

${ }^{362}$ HERSHOVITZ, The End of Jurisprudence, p. 1164-1165

${ }^{363}$ RAZ, The Authority of Law, p. 157

${ }^{364}$ HERSHOVITZ, The End of Jurisprudence, p. 1165

${ }^{365}$ HERSHOVITZ, The End of Jurisprudence, p. 1174-1180

${ }^{366}$ HERSHOVITZ, The End of Jurisprudence, p. 1180-1181

${ }^{367}$ HERSHOVITZ, The End of Jurisprudence, p. 1181-1186
} 
normatividade. ${ }^{368}$ Não existe, por assim dizer, um "ponto de vista do xadrez" para definir o que alguém deve ou não fazer em uma partida.

Esse exemplo do xadrez, por ser o mais complexo e o com mais semelhanças com o direito - há um sistema de regras, há instituições que criam e aplicam essas regras, etc. merece um pouco mais de atenção. Por que não é possível dizer que existe um "ponto de vista do xadrez" ou um "ponto de vista da Federação Mundial de Xadrez"? Porque as regras da Federação não existem no vácuo, responde Hershovitz. Elas têm uma história - foram adotadas pela Federação - e é à luz dessa história que alguém pode ter alguma razão para se importar com elas. Considerando isso, podemos concluir que alguma partida em particular, uma partida que faça parte de um torneio oficial, é governada pelas regras da Federação. Mas, mais importante, mesmo nesse caso, é possível que a partida não seja governada pelos padrões retirados estritamente das regras da Federação. Pode-se, por exemplo, apelar à intenção daqueles que elaboraram essas regras ou aos padrões que melhor serviriam ao propósito da Federação quando adotou essas regras. ${ }^{369}$ Essas formas de identificar as obrigações daqueles que estão jogando uma partida de xadrez apontam para o fato de que “as razões que as pessoas têm para prestar atenção às regras da Federação Mundial de Xadrez afetam os padrões que governam seu comportamento".370

O paralelo com a disputa entre uma abordagem baseada na "intenção do legislador" e uma baseada em integridade a partir da identificação do point do direito é evidente. Por isso, Hershovitz argumentará que, por mais que se atribua um point à prática jurídica que servirá à construção de proposições corretas sobre o que ela exige, não existe um "ponto de vista do direito", assim como não existe um "ponto de vista do xadrez". É nesse sentido que ele afirma que

podemos pensar nela [em sua proposta] como uma forma de eliminativismo, já que ela nega a existência de uma entidade - um domínio distintamente jurídico de normatividade ou quasenormatividade - que abordagens mais tradicionais pressupõem. ${ }^{371}$

\footnotetext{
368 "The world is full of practices that are law-like, in that they aim to shape the norms that govern our lives. But we don't take the vast majority of these practices to give rise to their own distinct domain of normativity, or even quasi-normativity, in the way that this picture supposes that legal practices do. [...] If I am right, then we should wonder whether we can navigate law without generating those problems too." (HERSHOVITZ, The End of Jurisprudence, p. 1174)

${ }^{369}$ HERSHOVITZ, The End of Jurisprudence, p. 1184

${ }^{370}$ HERSHOVITZ, The End of Jurisprudence, p. 1186

${ }^{371}$ HESHOVITZ, The End of Jurisprudence, p. 1193
} 
A abordagem eliminativista teria a vantagem positivista - a referência é a Raz - de ser "realista e não romântica", ao permitir que falemos claramente sobre a diferença entre o que nossas práticas jurídicas são e o que elas deveriam ser, sem a desvantagem de adotar a proposta "misteriosa" de que nossa prática jurídica cria direitos e obrigações especificamente jurídicos. Teria também a vantagem antipositivista de acatar a sugestão de Dworkin de que as pessoas discordam a respeito do que o direito requer porque elas discordam a respeito do significado moral das práticas jurídicas. ${ }^{372}$

A "eliminação" do direito não significaria, porém, que não mais teríamos que perguntar o que temos que fazer dentro de nossas práticas jurídicas. ${ }^{373}$ Como resume Hershovitz,

ainda nos perguntaríamos o que o direito requer de nós. A única diferença seria que quando o fizéssemos, consideraríamos que estamos engajados em uma investigação moral, ou talvez prudencial, ao invés de em uma investigação especificamente jurídica. Isto é, consideraríamos que estamos perguntando o que nossa prática jurídica nos dá razões morais ou prudenciais para fazer. ${ }^{374}$

Poderíamos ainda falar sobre o que o direito requer, mas não devemos supor que exista uma entidade única chamada "direito". Com isso, mais do que dizer, como faz Dworkin, que o direito é parte da moral, Hershovitz está dizendo que não existem critérios para se dizer o que é e o que não é direito. A caracterização de um “domínio jurídico” apenas poderia ser feita para propósitos específicos ${ }^{375}$, de forma semelhante ao que vimos em relação aos conceitos sociológicos de direito conforme a tipologia dworkiniana.

\footnotetext{
372 HERSHOVITZ, The End of Jurisprudence, p. 1194-1195

${ }^{373}$ Hershovitz também desenvolve um argumento de que teríamos razões para falar "como se" o direito gerasse obrigações especificamente jurídicas mesmo que ele não o faça (p. 1190); por exemplo, seria uma simplificação dizer que "os juízes devem aplicar as leis", mas pode ser melhor falarmos dessa forma do que fazermos a qualificação de que "juízes estão obrigados a aplicar as leis a não ser que sejam moralmente repugnantes”, pois tal qualificação, embora verdadeira, poderia levar a um abuso de poder por parte dos juízes (p. 1191).

Acredito que essa forma de "identificar" o direito não atende nem a uma abordagem de busca de sua natureza, como a feita por Raz, nem a uma abordagem sobre que tipo de obrigações o direito impõe, como a feita por Dworkin (afinal, não pretende dizer o que os juízes devem fazer, mas sim apresentar uma proposição que induza os juízes a fazerem o que eles devem fazer). Permite, ainda, que o teórico faça afirmações que, nos termos de sua própria teoria, não são verdadeiras (por exemplo, o teórico dirá que o juiz tem obrigações que, na verdade, não tem). Penso, porém, que essa parte do argumento é independente das demais e que, por isso, pode ser ignorada.

${ }^{374}$ HERSHOVITZ, The End of Jurisprudence, p. 1173

375 "When we have a project in mind, we can ask whether it matters what notion of law we employ, and which one to use if it does. But these are practical questions, not metaphysical ones" (HERSHOVITZ, The End of Jurisprudence, p. 1203)
} 
Assim, o "domínio jurídico" poderia ser distinto conforme o interesse de quem o delimitasse fosse mais moral ou mais prudencial e, ainda, mesmo que restrito à moral, poderia variar conforme a ocasião, como ocorreria quando perguntamos sobre o que o direito requer de diferentes autoridades de diferentes poderes. ${ }^{376} \mathrm{O}$ importante seria que a teoria do direito abandonasse a questão "metafísica" de saber o que é o domínio jurídico e passasse a se preocupar com responder como nossas práticas jurídicas afetam nossos direitos, obrigações, privilégios e poderes morais. ${ }^{377}$

\subsection{POR QUE AINDA DISTINGUIR O DIREITO DE OUTROS RAMOS DA MORALIDADE?}

A questão que Hershovitz coloca não é trivial. De fato, se aceito o argumento desenvolvido nos capítulos anteriores sobre o conceito doutrinal do direito e sobre a teoria do direito como uma teoria sobre tal conceito, que pretenda nos dizer - como cidadãos ou autoridades, inclusive juízes - o que fazer, poderíamos rapidamente chegar à conclusão de que não existe porque continuarmos presos ao conceito de direito para definirmos quais são nossas responsabilidades.

Se as teorias do direito descritivas, como a de Raz, têm entre suas principais preocupações a questão da definição das fronteiras do direito, distinguindo o que é direito e o que não é 378 , porque, ao adotarmos uma teoria abertamente normativa como a de Dworkin deveríamos manter essa preocupação? Não seria melhor enfrentar diretamente a questão de quais são as obrigações de cada pessoa em cada situação? Diríamos, então, que um juiz tem obrigação de seguir o que decide o Congresso, contanto que esse Congresso seja eleito e contanto que o que o Congresso decidiu siga o que está previsto na Constituição, por exemplo. Não existiria razão para perder tempo com saber "o que o direito é" para, a partir disso, dizer o que esse juiz deve fazer. Acredito, porém, que isso é uma extrapolação exagerada do argumento de Dworkin que venho apresentando até aqui.

\footnotetext{
${ }^{376}$ HERSHOVITZ, The End of Jurisprudence, p. 1202-1203

377 "The time has come for jurisprudence to drop the metaphysics and take up morals. The question that jurisprudence should aim to answer is how our legal practices affect our moral rights, obligations, privileges, and powers. The metaphysical question posed in the Hart-Dworkin debate was a distraction; we have no good reason to think that our legal practices generate a distinctively legal domain of normativity, or quasinormativity, whose metaphysics we must unravel. But the moral question is vital; it is contested every day, in court and out, with serious consequences for peoples' lives." (HERSHOVITZ, The End of Jurisprudence, p. 1203)

378 PRIEL, The Boundaries of Law..., p. 3
} 
Uma teoria abertamente normativa como a de Dworkin tende a, de fato, retirar a importância de individualizarmos padrões como jurídicos. Ela foca nossa atenção em quais são os direitos e responsabilidades que as pessoas têm ao invés de em descrever o que seria a estrutura de uma norma, o que faz com que uma norma seja jurídica, o que individualiza uma norma, etc. Ela nos afasta, isto é, de um conceito taxonômico de direito. Mas isso não significa que o conceito doutrinal de direito deva ser abandonado. Como Dworkin dizia já em $O$ Modelo de Regras II:

A teoria do direito coloca a pergunta: o que é o direito? Na sua maior parte, os filósofos do direito têm tentado responder a essa pergunta distinguindo os padrões que figuram, maneira apropriada, nos argumentos em favor de direitos e deveres jurídicos. Contudo, se esta lista restrita de padrões não puder ser feita, será preciso encontrar algum outro modo de distinguir os direitos e deveres jurídicos de outros tipos de direitos e deveres. ${ }^{379}$

A insistência na individualização de normas seria tão sem sentido quanto, no exemplo dado por Dworkin, perguntar a alguém que acabou de ler um livro extenso de geologia quantas "proposições de fato" o livro contém e qual teoria foi usada para contálas. $^{380}$

Negar a pertinência de um conceito taxonômico de direito não significa, portanto, negar a pertinência do conceito doutrinal de direito. Mas ainda se mantém a questão: temos alguma razão para continuarmos preocupados com este último? Por que não adotar o eliminativismo proposto por Hershovitz e tratar as questões jurídicas diretamente como questões morais?

Vimos que Raz afirma que "uma vez que assumimos que é possível que uma população não seja governada pelo direito, deve haver uma diferença entre padrões jurídicos e aqueles que não são jurídicos, que não são parte do direito". Esse truísmo não deve nos levar a um conceito taxonômico de direito, que pressupõe que existe uma série finita de normas que podem receber a etiqueta "direito", mas ele chama atenção para que dizer que uma comunidade é governada pelo direito significa alguma coisa. Significa que

a força não será usada [used or withheld], não importa o quão útil isso possa ser para os fins que se tem em vista, exceto quando permitido ou requerido por direitos e responsabilidade individuais que 
decorrem de decisões políticas passadas a respeito de quando o uso coletivo da força está justificado. 381

Isto é, é importante saber o que o direito é porque, como regra, apenas ele deve autorizar a coerção. Trata-se de uma atitude especifica em relação ao uso da força, específica àquelas comunidades que adotam a forma direito para organizar sua vida social. $\mathrm{O}$ direito pode ser parte da moral, mas ele tem essa especificidade de justificação da utilização da força que tenho destacado e, mais do que isso, de justificação de utilização da força com base em decisões politicas passadas, que outros ramos da moral não têm. ${ }^{382}$

A especificidade de justificação da utilização da força é o que diferencia, na verdade, a moralidade individual (como cada pessoa deve se comportar para com outras pessoas) da moralidade política (como a comunidade política deve tratar seus cidadãos). Como indivíduos, não temos obrigação de tratar a todos com igual consideração. A princípio, um pai não comete nenhum desvio moral ao preferir gastar recursos com a saúde do seu filho a fazer uma doação a uma ONG como a Médicos sem Fronteiras. Mas, como comunidade política (ou como governantes), existe tal obrigação. O que justifica essa diferença? É justamente a coercitividade que existe na política:

O que explica essa diferença [entre a moralidade individual e a moralidade política], eu acredito, é o fato que eu já mencionei: a política é coercitiva. Estamos todos em posição de podermos ser prejudicados por outros de uma forma que não seria permitida pela moralidade pessoal. Estamos nessa posição porque somos parte de uma união política. ${ }^{383}$

Nosso conceito de direito pressupõe que essa utilização da força poderá ser feita apenas com base em decisões políticas passadas. A referência a decisões políticas passadas explica como o direito pode ser parte da moral sem que se negue o truísmo de que o direito é diferente em cada país:

Por que não dizemos que nações que adotaram leis de zoneamento diferentes das nossas não compreenderam o conceito de direito [...]? Porque qualquer concepção plausível do direito e da justiça deve pressupor que decisões locais têm uma força em fixar o que o direito requer que elas não têm em relação à fixação de o que é justo ou injusto. Diferentes teorias do direito entendem de forma

\footnotetext{
381 DWORKIN, Law's Empire, p. 93

382 "The distinctive thing about law is not just that it is concerned with state force (though it is). The distinctive thing is that law embodies a particular attitude towards state force. Law places enormous emphasis on the point that the public justification of coercion is to be oriented to past events, like enactments and precedents." (WALDRON, Jurisprudence for Hedgehogs, p. 8-9)

${ }^{383}$ DWORKIN, R. Keynote address. Boston University Law Review, v. 90, 2010, p. 476-477
} 
diferente a força de decisões locais; mas qualquer teoria competente dá a tais decisões muito mais força no direito do que na moralidade. Mesmo quando entendemos que o direito é um ramo da moralidade [...] devemos aceitar essa distinção indispensável entre este ramo e o resto do domínio. ${ }^{384}$

Serão justamente essas especificidades que, como temos visto, guiarão a identificação de o que o direito é, através da elaboração de diferentes concepções de direito. Ao nos engajarmos em um argumento sobre qual é a melhor teoria (concepção) do direito buscamos justamente justificar a utilização ou ameaça de utilização da força pelo estado com base em decisões passadas; procuramos construir uma teoria do direito compatível tanto quanto possível com uma obrigação de obedecer ao direito. ${ }^{385}$ Nas palavras de Dworkin, ao adotarmos a ideia de que o direito é parte da moral, somos

encorajados a ver as questões de filosofia do direito como questões morais sobre quando, até onde e porque razão decisões coletivas autoritativas e convenções específicas deveriam ter a última palavra em nossas vidas. ${ }^{386}$

Questão diversa, mas conectada à da identificação, é se temos alguma razão para defender que nossa sociedade seja organizada pelo direito, por um império do direito, permitindo-se a utilização da força apenas com base nele. Aqui, serão mobilizados argumentos sobre que valor esse tipo de organização pode ter em comparação a outras organizações, argumentos relacionados ao que se chama de Estado de Direito, legalidade ou rule of law.

Se, por outro lado, adotássemos o "eliminativismo" proposto por Hershovitz perderíamos a possibilidade de construir argumentos como esses, já que não haveria nada que distinguisse o direito de outras formas de governança. ${ }^{387}$ Além disso, a prática jurídica não poderia ser vista como uma constante defesa dos ideais relacionados ao Estado de Direito.

\footnotetext{
${ }^{384}$ DWORKIN, Justice for Hedgehogs, p. 171

385، The interpretivist says that the justifying connection between institutional practice and legal rights and obligations must be such as to serve as an adequate response to the moral concern that is characteristic of legal practice. On the hypothesis we have been discussing, the concern is raised by coercive enforcement. A conception of law must therefore articulate the relation that must hold between some right or obligation and institutional practice if the right or obligation is to be permissibly enforced" (STRAVOPOULOS, Legal Interpretivism, p. 14)

${ }^{386}$ DWORKIN, Introduction: Law and Morals, p. 35

${ }^{387}$ Raciocínio semelhante é feito por Dworkin em relação ao conceito de "democracia". Por que não deixar de discutir o que é democrático e o que não é e simplesmente discutir qual forma de governo é melhor? Porque isso "nos força a ignorar valores diferentes que estão em jogo nessa última questão" (DWORKIN, Justice for Hedgehogs, p. 383)
} 
Retomar um argumento anterior sobre como a concepção de direito de Dworkin é defendida pode deixar mais claro o que isso significa. Vimos que Dworkin defende sua concepção de direito como integridade a partir do valor da igualdade (subseção 3.2.1, acima). $\mathrm{O}$ direito assim compreendido garantiria uma reciprocidade entre os cidadãos que faria com que, mesmo submetidos a autoridades estatais, eles não estivessem sujeitos a uma espécie de subordinação que comprometesse suas dignidades. ${ }^{388}$ Esse é o valor relacionado a ter um Estado de Direito e não outra forma de organização social e é a esse valor que uma defesa do Estado de direito se voltará.

Manter a possibilidade de distinguir o que é e o que não é direito permite que aqueles que se engajam na prática jurídica - autoridades, juízes, advogados e cidadãos em geral possam fazer desse engajamento uma constante defesa desses ideais de igualdade. Serão esses ideais que darão sentido à atividade desses participantes na prática jurídica. ${ }^{389}$ Adotada a integridade, por exemplo, esse engajamento se dará por uma busca contínua de que o Estado fale com "uma só voz", utilizando a coerção de forma coerente em princípio para todos os cidadãos, busca cujo sentido é, em última análise, a defesa da igualdade como valor político.

Um contra-argumento interessante sobre a necessidade de se distinguir o direito do restante da moralidade é que não há evidências de que o debate sobre os limites do direito seja relevante na prática jurídica e que, por isso, não haveria elementos suficientes (a serem colhidos na prática jurídica) para construirmos uma teoria sobre quais seriam esses limites. As fronteiras do direito seriam, assim, uma questão indeterminada e à teoria do direito caberia apenas descrever essa indeterminação. ${ }^{390}$

Esse argumento poderia ser correto se entendêssemos a tarefa da teoria do direito como Raz a entende, se a definição do direito fosse dada por uma análise conceitual politicamente neutra. Ou, ainda, se estivéssemos preocupados com um conceito de direito de tipo sociológico, como tratei na Seção 3.6. A defesa de que existe uma "fronteira" entre o que é direito e o que não é será feita, porém, não por uma análise neutra conceitual de

\footnotetext{
${ }^{388}$ DWORKIN, Justice for Hedgehogs, p. 319-320

${ }^{389}$ Como afirma Dworkin em relação à prática da cortesia: "Each citizen, we might say, is trying to discover his own intention in maintaining and participating in that practice [...] in the sense of finding a purposeful account of his behavior he is comfortable in ascribing to himself' (DWORKIN, Law's Empire, p. 58)

${ }^{390}$ É o argumento feito em PRIEL, The Boundaries of Law and the Purpose of Legal Philosophy, especialmente p. $10-14$
} 
estilo raziano nem por uma análise sociológica, mas por um argumento de moralidade política de justificação da coerção. Cada decisão de um juiz ou de uma autoridade pública que se fundamente no direito para impor alguma sanção ou dar uma ordem cujo descumprimento pode implicar uma sanção pressuporá - terá em seu "prólogo silencioso" essa fronteira. As fronteiras do direito são as fronteiras do poder coercitivo estatal e, por isso, devem ser construídas com cuidado.

\subsection{SIGNIFICADO E IMPLICAÇÕES DO DIREITO ENTENDIDO COMO PARTE DA MORAL}

Já apresentei os argumentos de Hershovitz a favor do que ele chama de eliminativismo, bem como quais eu entendo serem as razões para que tais argumentos não sejam acolhidos. Afirmei que o caminho que a teoria do direito de Dworkin toma colocandose como uma teoria abertamente normativa e negando uma abordagem taxonômica de direito parece sugerir que a identificação de o que é o direito deveria ser abandonada, mas que, na verdade, a centralidade da legitimidade faz com que esse ainda seja um empreendimento fundamental. O que significa, então, a mudança teórica de Dworkin? O que significa e que implicações tem a afirmação de que o direito faz parte da moral?

Para responder a essa pergunta, é interessante observarmos, antes, semelhanças e diferenças que existem nesse ponto entre Raz e Dworkin. Diferentemente do que fazem outros positivistas, Raz não trata da moralidade e do direito como dois "pontos de vista" diferentes ${ }^{391}$ e não coloca no centro de suas preocupações uma pergunta do tipo "como a moralidade afeta o direito?". Falar sobre "moralidade” é, conforme Raz, apenas uma forma de falar de razões que pessoas têm para agir. Todos devem agir moralmente simplesmente porque a moralidade é composta de razões ${ }^{392}$, de modo que a pergunta pertinente a ser feita

${ }^{391}$ RAZ, Incorporation by Law, p. 6

392 RAZ, Incorporation by Law, p. 2; "I will assume that there are reasons which are not themselves part of any point of view and which determine when it is appropriate to resort to points of view. Now morality, I think, must be part of those background considerations which we resort to in virtue of being rational animals. i.e. reasoning animals. Put it a different way: there are values and reasons which unconditionally govern our thought. We call some of them moral. Which are moral and which are not seems to me to be a matter of classificatory convenience, and not anything of any great moment. The thought that that is not so, in particular the thought that morality constitutes a point of view such that the proper occasions to resort to it are determined by non-moral considerations, seems to run counter to central features in our understanding of the role and importance of morality.” (RAZ, On the Autonomy of Legal Reasoning, p. 329) 
pelo teórico é como o direito modifica essas razões, como o direito modifica a moralidade e não o contrário.

Não faz sentido para Raz dizer que o Estado é "juridicamente legítimo", a legitimidade implica um poder de impor obrigações e, assim, não pode dizer respeito a nada que não sejam princípios morais. ${ }^{393}$ Também as decisões daqueles se engajam na prática jurídica são decisões morais. Como ele afirma em relação às decisões dos tribunais:

Claramente, as decisões das cortes afetam autores e réus de maneiras substanciais e cada decisão tomada por uma pessoa que afete significativamente o destino de outras é, além de qualquer outra coisa que ela possa ser, uma decisão moral. ${ }^{394}$

Até este ponto, Raz e Dworkin estão de acordo. A teoria do direito de Raz, ainda assim, não é uma teoria normativa porque ela se limita a dizer que obrigações o direito colocaria caso ele fosse legítimo. Ela pressupõe, como diz Hershovitz, que as práticas jurídicas criam um domínio de quase-normatividade. Mais importante, para Raz, embora o direito possa modificar a moralidade, a moralidade não afeta a forma como o direito deve ser identificado.

A afirmação de Dworkin de que o direito faz parte da moralidade traz, primeiramente, o mesmo tipo de ganho de clareza que trazem as afirmações de Raz sobre a moralidade não ser meramente um "ponto de vista" e sobre as decisões judiciais serem decisões morais. Isto é, ela destaca a responsabilidade moral envolvida em decisões tomadas na prática jurídica, afastando uma certa mistificação sobre o que a "técnica jurídica" poderia impor. Não acredito, porém, que signifique uma reformulação das principais teses que ele desenvolvera até Justice in Robes. Os argumentos que vimos ao longo dos capítulos 3 e 4 sobre a centralidade da legitimidade já indicam que direito e moralidade não poderiam ser vistos como domínios distintos. ${ }^{395}$

Outra consequência importante é o afastamento de qualquer leitura de Dworkin como teórico de um conceito taxonômico de direito. Como afirmei na Introdução, entre muitos Dworkin ainda é conhecido por sua distinção entre princípios e regras, apresentada em seu

\footnotetext{
${ }^{393}$ RAZ, Incorporation by Law, p. 5-6

${ }^{394}$ RAZ, On The Autonomy of Legal Reasoning, p. 327-328

${ }^{395}$ O próprio Dworkin indica que se afastou da descrição do direito e da moralidade como dois sistema distintos a partir de $O$ Modelo de Regras II, embora apenas tenha percebido essa diferença completamente mais tarde quando começou a considerar as principais questões de que trata em Justice for Hedgehogs (DWORKIN, Justice for Hedgehogs, p. 402).
} 
artigo O Modelo de Regras I. Sobretudo segundo uma leitura mais manualesca de sua obra, ele teria identificado a "natureza" desses dois tipos de norma, que seria a chave para a resolução de uma série de problemas jurídicos, especialmente de Direito Constitucional. É possível disputar se essa leitura era possível considerado esse artigo isoladamente - e o próprio Dworkin diz que, quando o escreveu, tinha uma visão errada sobre a relação entre direito e moralidade ${ }^{396}$-; de qualquer forma, com a afirmação de que o direito é um ramo da moralidade esse tipo de leitura não é mais sustentável. Se há algum ganho na utilização da categoria "princípio", ele está apenas em como ela destaca uma necessidade mais direta de justificação moral ${ }^{397}$.

Dworkin defende que também é uma implicação de vermos direito e moral como um único sistema a distinção entre direitos jurídicos e "direitos legislativos", correspondendo os primeiros àqueles que as pessoas têm direito de que sejam aplicados a seu pedido independentemente de alguma nova decisão do Legislativo e os segundos àqueles direitos que a comunidade tem de que a atividade legislativa seja exercida de uma determinada forma. ${ }^{398}$ Esse ponto merece um pouco mais de atenção.

Essa distinção de Dworkin pode parecer pouco persuasiva porque não são usuais as expressões "direitos legislativos" e "direitos jurídicos" e porque não utilizamos esta última com o sentido de "direitos que podem ser exigidos judicialmente". Se alguém se referir a algum direito social, como o direito à saúde e o direito à moradia (art. $\left.6^{\circ}, \mathrm{CF}\right)$, como direitos “não jurídicos”, ele provavelmente será corrigido - afinal, esses direitos estão na Constituição. Mas, deixando de lado a terminologia, podemos ver que a distinção proposta por Dworkin é uma decorrência dos argumentos que temos visto até aqui.

Quando nos perguntamos quais são os fundamentos do direito - do conceito doutrinal de direito - estamos nos perguntando quais são os critérios de verdade para que uma proposição jurídica seja verdadeira. Como vimos, a resposta deve ser construída de modo que a referência a tal conceito doutrinal possa justificar a utilização ou a ameaça de utilização da força ${ }^{399}$. Um direito que não possa, mesmo em tese, ser levado a um tribunal

\footnotetext{
${ }^{396}$ DWORKIN, Justice for Hedgehogs, p. 402

${ }^{397}$ MACEDO Jr., O direito em desacordo, p. 35-36

${ }^{398}$ DWORKIN, Justice for Hedgehogs, p. 406

${ }^{399}$ Embora crítico do argumento de Dworkin de que apenas existem direitos jurídicos exigíveis judicialmente, Lawrence Sager afirma que "suspeita" que, no fundo, o que justifica tal argumento é a centralidade da coerção: "Still elusive is what motivates Dworkin's insistence that a legal claim must be entitled to immediate recognition by the judiciary. In the end, Dworkin never really defends this. But his demand that judicial
} 
não estará relacionado a essa utilização da força - sua inobservância não pode ser punida assim - e deve ser identificado através de outro tipo de consideração.

A pergunta colocada pelo conceito doutrinal de direito é uma pergunta sobre como deve ser feita a adjudicação por magistrados não porque os membros do Judiciário têm algo de especial, mas porque, na forma como se organizam países como os Estados Unidos e o Brasil, o Judiciário tem o poder de dar a última palavra sobre os direitos e deveres que, em um dado momento ${ }^{400}$, os cidadãos e as autoridades têm e essa última palavra está acompanhada de uma ameaça ou de utilização de força. Nada mudaria na construção de nossa teoria se essa última palavra passasse a ser dada por algum outro tipo de instituição adjudicatória, ligada a outro poder.

A existência de uma instituição adjudicatória - não necessariamente componente do Poder Judiciário - que deve se guiar por determinados padrões - padrões jurídicos - para decidir é, porém, necessária para a construção de uma teoria como a de Dworkin. ${ }^{401}$ Mesmo ao tratar do Direito Internacional, para o qual não há tal instituição, Dworkin sugere que se imagine uma "Corte Internacional Hipotética" ao qual possam ser levadas demandas e que tenha poder para impor sanções, de modo que o que tal corte estivesse obrigada a decidir corresponderia ao conteúdo do direito internacional ${ }^{402}$.

enforcement be involved if a proviso is to be law has two parts. The first is that there an adjudicative body which will respond to entitlements on demand; the second is that the body in question have authority over the police or other coercive entities. It is possible that coercion is at the bottom of all this. The point of law, for Dworkin, is that it delineates the appropriate and necessary occasions for the collective use of force, that it directs and legitimates the coercive authority of the state. Courts, in Dworkin's view, direct or command collective force; legislatures and other nonjudicial bodies and officials - including citizens in their sovereign constitution-making roles - do not. Hence judicial enforceability as the sine qua non of law." (SAGER, Putting Law in its place, p. 127). Acredito que sua suspeita está correta.

${ }^{400} \mathrm{Com}$ isso, quero dizer que os direitos que os direitos que as pessoas têm podem ser modificados pelo Legislativo posteriormente.

${ }^{401}$ Raz afirma que Dworkin não tinha uma teoria do direito, mas apenas uma teoria da adjudicação, o que teria mudado a partir de Law's Empire, quando teríamos "a concept of law that is totally independent of any reference to adjudication" (RAZ, J. Dworkinian Integrity and Coherence. Oxford: Blackwell Publishing, 2004, p. 287), mas na verdade, como o próprio Dworkin destaca em resposta a esse artigo de Raz, ele "do think that a theory of law is a theory of adjudication, but that is not surprising because I mean, by the latter, a theory of how judges should identify and enforce people's legal rights, that is, how they should acquit their institutional duty to apply the law" (DWORKIN, Replies, p. 382).

402 "Let us imagine (though initially not in much detail) an international court with jurisdiction over all the nations of the world. We imagine that cases can be brought before that court reasonably easily and that effective sanctions are available to enforce the court's rulings. [...]

If we can imagine such a court, even as fantasy, then we can frame a tractable question of political morality. What tests or arguments should that hypothetical court adopt to determine the rights and obligations of states (and other international actors and organizations) that it would be appropriate for it to enforce coercively? This is a moral question but a special one because judicial institutions with compulsory jurisdiction and sanctions at their disposal are subject to special moral standards of legitimacy and fairness. They have no right to declare 
Insistir que também são jurídicos direitos que não podem ser exigidos judicialmente demandaria outro método para que tais direitos fossem identificados. Como vimos, a escolha de teorias como o convencionalismo e a integridade está diretamente relacionada à justificação da coerção; se tais direitos não podem ser exigidos judicialmente, não há coerção a justificar.

A importância do Judiciário nesse quadro deve ser acompanhada das mesmas ressalvas feitas na Seção 3.4. Ela não significa que a interpretação do direito seja monopólio dos tribunais. Para identificar seus direitos e responsabilidades, autoridades e cidadãos em geral devem fazer o mesmo tipo de raciocínio que deveria ser feito por um juiz, não porque o juiz tenha alguma capacidade moral superior ${ }^{403}$, mas apenas porque ambos estão submetidos ao mesmo direito.

and enforce general standards of comity, decency, or wisdom. We can identify a general theory of what it would be appropriate for such an institution to enforce as the foundation of international law." (DWORKIN, A New Philosophy for International Law, p. 14)

${ }^{403}$ Isso também é dito por Raz: "[...] it is not my view that legal reasoning is exclusive to the courts, or that it has a special character when undertaken by the courts. [...] It is sometimes thought that the special position of the courts implies that there is a special form of judicial reasoning all their own. This is not so. Courts' decisions are legally binding; the decisions of ordinary people are not, at least not normally. But it does not follow that courts reason in a special way. We may - people sometimes do - think of problems which arise before the courts. reasoning about the merits of the case for plaintiff or defendant we reason-if we reason well-as the courts do, if they reason well." (RAZ, On The Autonomy of Legal Reasoning, p. 327) 


\section{Conclusões}

Comecei este trabalho perguntando se era possível enfrentarmos a questão de o que o direito é de forma independente da questão da obrigação política. Apresentei a teoria do direito de Joseph Raz como exemplo de resposta positiva a essa pergunta para, em seguida, apresentar o argumento de Ronald Dworkin em sentido contrário.

Acredito que uma teoria como a de Raz, que apresentei no Capítulo 2, leva a um nível mais alto de consistência e abstração um certo modo de pensar o direito que está muito enraizado em nossa experiência cotidiana. Refiro-me a uma abordagem descritiva e categorizadora, do tipo que nos apresenta $o$ que são conceitos relevantes para a prática jurídica - por exemplo, o que é "norma", o que é "fato jurídico", o que é "poder de polícia", o que é "ato administrativo" - e, a partir deles, retira consequências sobre deveres, especialmente deveres das autoridades públicas. A diferença de Raz é que ele reconhece que sua teoria, descritiva, não pode ter implicações sobre o que as pessoas devem fazer, dependendo de um argumento de moralidade política, como destaquei também no Capítulo 5.

É difícil, porém, conceber que a afirmação de o que o direito é não tenha (e não deva ter) per se nenhuma consequência prática sobre a forma como as pessoas se comportam. $\mathrm{O}$ conceito de direito - o conceito doutrinal de direito - funciona para nós como justificação; funciona, isto é, “incorporado em uma prática que pressupõe que proposições jurídicas têm implicações para o exercício do poder" ${ }^{\prime 404}$. Ele é utilizado por juízes, autoridades e cidadãos em geral como fundamento para ameaças de utilização justificada da força e isso deve ser considerado na construção de uma teoria sobre esse conceito, que deve fazer sentido dessa utilização, como pretendi mostrar no Capítulo 3.

Se o conceito de direito tivesse alguma "natureza" ou "essência" poderíamos descrevê-las para, por fim, através de uma teoria política independente, chegar à conclusão de que sua utilização para justificação do uso da força está simplesmente equivocada e deveria ser abandonada. Mas essa natureza ou essência não existem. O conceito de direito é objeto de uma série de controvérsias e a melhor forma de compreendê-las é como 
divergências sobre como melhor justificar uma obrigação de obedecer ao direito e a coerção que acompanha o descumprimento dessa obrigação. Buscamos uma teoria plausível do direito que possa fornecer tal justificação. Se fracassamos, devemos adotar uma posição cética; se bem-sucedidos, adotamos teorias do direito não-céticas. Afirmei isso no Capítulo 3 , apresentando os diferentes points que podem ser atribuídos ao direito por teorias nãocéticas, por exemplo pelo convencionalismo ou pelo direito como integridade, e como essa atribuição de um point torna a teoria do direito abertamente normativa, com pretensões de dizer o que aqueles que se engajam na prática jurídica devem fazer.

A má percepção dos positivistas sobre como funciona o conceito de direito, de seu papel justificatório, pode ter sua origem atribuída a uma espécie de confusão conceitual. Mais especificamente, a insistência positivista na busca de uma "natureza" para o direito pode ser creditada à compreensão do conceito de direito como um conceito criterial, cujos critérios de verdade são dados convencionalmente, e não como o que Dworkin chama de um conceito interpretativo, cujos critérios de verdade estão ligados à atribuição de um propósito. Como procurei mostrar no Capítulo 4, essa confusão faria com que, mesmo diante da importância decisiva de dizer o que o direito é e das controvérsias (morais) que se alastram pela prática jurídica, o positivista ainda mantivesse a pretensão de construir uma teoria neutra e descritiva.

Todo esse argumento pela inexistência de uma natureza do direito a ser descrita pelo teórico e sobre a necessidade de construção de uma teoria abertamente normativa que oriente a ação dos cidadãos e autoridades culmina na defesa por Dworkin da tese de que o direito é apenas um departamento da moralidade. Essa tese poderia nos levar a simplesmente abandonar o empreendimento de construção de uma teoria do direito; abandonar, pelo menos, a pretensão de tentar dizer o que é direito e o que não é, de identificar os fundamentos do direito, entendidos como os critérios de verdade das proposições jurídicas. Esse é o argumento de Scott Hershovitz, que apresentei no Capítulo 5 e que critiquei pelo que entendo ser uma incompreensão do papel especial que o direito tem na justificação da coerção, tornando-a dependente de decisões autorizadoras passadas e não de outra consideração moral qualquer. Uma teoria abertamente normativa do direito nos afasta de preocupações “taxonômicas” de individualização de regras e princípios, mas ainda é fundamental saber o que o direito é como ramo especial da moralidade preocupado com a permissão do uso da coerção estatal, informado por essa preocupação. 
A teoria do direito de Dworkin pressupõe que existe uma obrigação dos cidadãos de obedecer ao direito - obrigação que, caso não existisse, nos levaria a uma posição cética em relação à própria possibilidade de sentido de proposições jurídicas, como vimos na subseção 3.3.2 -, o que pode fazer com que ela pareça excessivamente deferente à autoridade política. Mas o que acredito que ela faça, na verdade, é destacar como nossa prática jurídica já pressupõe essa obrigação. Ao deixar isso claro, ela nos convoca a assumir a responsabilidade de tentar fazer com que essa pressuposição seja verdadeira, de modo a fazer com que nossa prática jurídica tenha sentido e não seja apenas uma arbitrariedade, um exercício puro de poder.

Se a integridade como concepção do direito é capaz de cumprir esse papel dentro de uma sociedade específica é outra questão, mas é importante notarmos qual deverá ser seu papel. Ela deverá mostrar que organizar essa sociedade através de normas que se aplicam a todos igualmente, de forma coerente em princípio, é mais legítimo do que outras formas de organização social.

Aceitas as conclusões que apresentei sobre o papel justificatório do direito e da teoria do direito, esta última ganharia alguns novos papeis e abandonaria alguns outros. Ela não mais teria em seu centro preocupações categorizadoras e descritivas da natureza do direito e de institutos jurídicos. Não se preocuparia, isto é, em dizer o que é uma norma, qual sua estrutura, quais suas espécies, nem se proporia a explicar "tecnicamente" o que o direito $e ́$ em oposição ao que ele deveria ser.

A teoria do direito se preocuparia, por outro lado, em identificar quais são as questões de moralidade política que estão por trás de divergências jurídicas em tribunais e na doutrina e em construir teorias consistentes para dar respostas a tais divergências. Ela assumiria a responsabilidade de lidar com o problema da legitimidade estatal e de dizer a cidadãos, autoridades e juízes quais são seus direitos e obrigações. 


\section{BIBLIOGRAFIA}

ALLAN, T. R. S. Law, Justice and Integrity: The Paradox of Wicked Laws. Oxford Journal of Legal Studies, v. 29, n. 4, 2009.

BUSTAMANTE, T. A Breve História do Positivismo Descritivo - O que resta do positivismo jurídico depois de H. L. A. Hart? Novos Estudos Jurídicos , v. 20, 2015.

BUSTAMANTE, T. Revisiting the Idea of Protestant Interpretation: Towards Reconciliation between Dworkin and Postema. Federal University of Minas Gerais Research Paper, Maio 2018. Disponível em: https://papers.ssrn.com/sol3/papers.cfm?abstract_id=3174455.

BUSTAMANTE, T. Revisiting Dworkin's Philosophy of International Law. Canadian Journal of Law and Jurisprudence, v. XXX, n. 2, Agosto 2017.

CHASKALSON, A. From wickedness to equality: the moral transformation of south african law. Institutional Journal of Constitutional Law, v. 1, n. 4, 2003.

COLEMAN, J. Law and Political Morality. APA Newsletters (Newsletter on Philosophy and Law), v. 6, n. 2, 2007.

DWORKIN, R. Comment on Narveson: In Defense of Equality. Social Philosophy \& Policy, v. 1, n. 1, p. 24-40, 1983.

DWORKIN, R. Comment on Narveson: In Defense of Equality. Social Philosophy \& Policy, v. 1, n. 1, p. 24-40, 1983.

DWORKIN, R. Political Judges and the Rule of Law. In: A Matter of Principle. Cambridge: Harvard University Press, 1985.

DWORKIN, R. Introduction. In: Freedom's Law: the moral reading of the american constitution. Oxford: Oxford University Press, 1996.

DWORKIN, R. Law's Empire. Oxford: Hart Publishing, 1998.

DWORKIN, R. Casos Difíceis. In: Levando os Direito a Sério. São Paulo: WMF Martins Fontes , 2002. 
DWORKIN, R. Replies. In: BURLEY, J. Dworkin and his critics - with replies by Dworkin. Oxford: Blackwell Publishing, 2004.

DWORKIN, R. Hart's Postscript and the Point of Political Philosophy. In: Justice in Robes. Cambridge: Belknap Press, 2006.

DWORKIN, R. In Praise of Theory. In: Justice in Robes. Cambridge: Harvard University Press, 2006.

DWORKIN, R. Introduction: Law and Morals. In: Justice in Robes. Cambridge: Harvard University Press, 2006.

DWORKIN, R. The Concepts of Law. In: Justice in Robes. Cambridge: Harvard Belknap Press, 2006.

DWORKIN, R. Thirty years on. In: Justice in Robes. Cambridge: Harvard University Press, 2006.

DWORKIN, R. Keynote address. Boston University Law Review, v. 90, p. 469-477, 2010.

DWORKIN, R. O Modelo de Regras II. In: Levando os Direitos a Sério. Tradução de Nelson Boeira. 3a . ed. São Paulo: WMF Martins Fontes, 2010.

DWORKIN, R. Response. Boston University Law Review, v. 90, n. 1059, 2010.

DWORKIN, R. Resposta aos Críticos. In: Levando os Direitos a Sério. Tradução de Nelson Boeira. 3a . ed. São Paulo: WMF Martins Fontes, 2010.

DWORKIN, R. Justice for Hedgehogs. Cambridge: Belknap Press, 2011.

DWORKIN, R. A New Philosophy for International Law. Philosophy and Public Affairs, v. 41, n. 1, 2013.

DWORKIN, R. Religion Without God. Cambridge: Harvard University Press, 2013.

DWORKIN, R. Hart's Posthumous Reply. Harvard Law Review, v. 130, 2017. 
DYZENHAUS, D. Dworkin and unjust law. In: WALUCHOW, W. J. The Legacy of Ronald Dworkin. Oxford: Oxford University Press, 2016.

EDMUNDSON, W. A. State of the Art: The Duty to Obey the Law. Legal Theory, v. 10, n. 4, p. 215-259, Dezembro 2004.

FABIENNE, P. Political Legitimacy. The Stanford Encyclopedia of Philosophy (Summer 2017 Edition), 2017. Disponivel em: <https://plato.stanford.edu/archives/sum2017/entries/legitimacy/>.

FERNANDES, R. B. Controle de Constitucionalidade e Democracia no debate entre Ronald Dworkin e Jeremy Waldron. Trabalho de Conclusão de Curso, Faculdade de Direito da Universidade de São Paulo. São Paulo. 2013.

FERRAZ JUNIOR, T. S. Introdução ao estudo do direito: técnica, decisão, dominação. $4^{\mathrm{a}}$ edição. ed. São Paulo: Atlas, 2003.

GARDNER, J. Nearly Natural Law. The American Journal of Jurisprudence, v. 52, n. 1, 2007.

GARDNER, J. Law's Aims in Law's Empire. In: HERSHOVITZ, S. Exploring Law's Empire: The Jurisprudence of Ronald Dworkin. Oxford: Oxford University Press, 2008.

GLEZER, R. E. O Positivismo de Joseph Raz: Autoridade e Razão Prática sem Prática Social. São Paulo: Universidade de São Paulo - Tese de Doutorado, 2014.

GREEN, L. Associative Obligations and the State. In: BURLEY, J. Dworkin and his critics. Oxford: Blackwell Publishing, 2004.

GREEN, L. Law and Obligations. In: COLEMAN, J. L.; HIMMA, K. E.; SHAPIRO, S. J. The Oxford Handbook of Jurisprudence and Philosophy of Law. Oxford: Oxford University Press, 2004.

GUEST, S. How to Criticize Ronald Dworkin's Theory of Law. Analysis, v. 69, n. 2, p. 352-364, Abril 2009. 
GUEST, S. Ronald Dworkin. 3a . ed. Stanford: Stanford University Press, 2013.

HART, H. L. A. The Concept of Law. $2^{a}$ edição. ed. Oxford: Clarendon Press, 1994.

HERSHOVITZ, S. The End of Jurisprudence. Yale Law Jornal, v. 124, n. 1160, 2015.

HIMMA, K. The Authorization of Coercive Enforcement Mechanisms as a Conceptually Necessary Feature of Law. https://papers.ssrn.com/sol3/papers.cfm?abstract_id=2660468, Setembro 2015.

LOPES, J. R. D. L. Filosofia analítica e hermenêutica: Preliminares a uma teoria do direito como prática. Revista de Informação Legislativa, Brasília, n. 212, p. 203-226, out/dez 2016.

MACEDO JR., R. P. Do Xadrez à Cortesia: Dworkin e a Teoria do Direito Contemporânea. Tese de Livre Docência, USP - Faculdade de Direito. São Paulo. 2012.

MACEDO JR., R. P. O direito em desacordo: o debate entre o interpretativismo e o convencionalismo jurídico. São Paulo: Tese apresentada ao concurso de Professor Titular - Departamento de Filosofia e Teoria Geral do Direito - USP, 2013.

MACEDO JR., R. P. Teoria, Filosofia e Dogmática Jurídica: Rigor e Método. In: MACEDO JR, R. P. (org.). Teoria do Direito Contemporânea. Curitiba: Juruá Editora, 2017.

MELLO, M. B. D. Teoria do Fato Jurídico - Plano da Existência. $16^{a}$ Edição. ed. São Paulo: Saraiva, 2010.

MURATA, D. Uma teoria dworkianina para os direitos humanos. Revista da Faculdade de Direito do Sul de Minas, Pouso Alegre, v. 33, n. 2, p. 384-409, 2017. 
MURATA, D. P. Em Meio à Tempestade: Valoração e Descrição na Teoria do Direito. Dissertação de Mestrado, USP - Faculdade de Direito. São Paulo. 2018.

MURPHY, L. The Political Question. In: COLEMAN, J. Hart's Postscript: Essays on the Postscript to the Concept of Law. Oxford: Oxford University Press, 2001.

NINO, C. S. Derecho, Moral, Politica. Doxa: Cuadernos de Filosofia del Derecho, v. 1, n. 14, p. 35-46, Junho 1993.

PASCHOALINI, F. Interpretação e Instituições: O Diálogo entre Cass Sunstein e Ronald Dworkin. In: MACEDO JR., R. P. (org.) Teoria do Direito Contemporânea. Curitiba: Juruá Editora, 2017.

PERRY, S. Law and Obligation. American Journal of Jurisprudence, v. 50, n. 1, 2005.

PERRY, S. Associative obligations and the obligation to obey the law. In: HERSHOVITZ, S. Exploring Law's Empire: The Jurisprudence of Ronald Dworkin. Oxford: Oxford University Press.

POSTEMA, G. A treatise of legal philosophy and general jurisprudence. New York: Springer, v. 11, 2011.

PRIEL, D. The Boundaries of Law and the Purpose of Legal Philosophy. Law and Philosophy, 2008.

PRIEL, D. The Place of Legitimacy in Legal Theory. McGill Law Journal, v. 1, n. $57,2011$.

RÉAUME, D. Is Integrity a Virtue? Dworkin's Theory of Legal Obligation. The University of Toronto Law Journal, v. 39, n. 4, 1989.

RAWLS, J. A Theory of Justice. Cambridge: Belknap Press, 1999.

RAZ, J. Authority and Justification. Philosophy \& Public Affairs, 1985.

RAZ, J. The Morality of Freedom. Oxford: Oxford University Press, 1986a. 
RAZ, J. The Relevance of Coherence. Boston University Law Review, v. 72, n. 2, 1992.

RAZ, J. Authority, Law and Morality. In: RAZ, J. Ethics in the Public Domain: Essays in the Morality of Law and Politics. Oxford: Clarendon Press, 1995.

RAZ, J. On The Autonomy of Legal Reasoning. In: Ethics in the public domain. Oxford: Clarendon Press, 1995.

RAZ, J. The Problem about the Nature of Law. In: Ethics in the Public Domain: Essays in the Morality of Law and Politics. Oxford: Clarendon Press, 1995.

RAZ, J. Postscript to the Second Edition: Rethinking exclusionary reasons. In:__ Practical Reason and Norms. Oxford: Oxford University Press, 1999.

RAZ, J. The Uniqueness of Law. In: Practical Reasons and Norms. Oxford: Oxford University Press, 1999.

RAZ, J. Dworkinian Integrity and Coherence. Oxford: Blackwell Publishing, 2004.

RAZ, J. Incorporation by Law. Legal Theory, Cambridge, n. 10, p. 1-17, 2004.

RAZ, J. A Right to Dissent? I. Civil Disobedience. In: The Authority of Law: Essays on Law and Morality. 2nd Edition. ed. Oxford: Clarendon Press, 2009.

RAZ, J. A Right to Dissent? II. Conscientious Objection. In: The Authority of Law: Essays on Law and Morality. 2nd Edition. ed. Oxford: Clarendon Press, 2009.

RAZ, J. Can There Be a Theory of Law? In: Between Authority and Interpretation - On the Theory of Law and Practical Reason. Oxford: Oxford University Press, 2009. 
RAZ, J. Legal Positivism and the Sources of Law. In: The Authority of Law: Essays on Law and Morality. 2nd Edition. ed. Oxford: Clarendon Press, 2009.

RAZ, J. Legal Reasons, Sources, and Gaps. In: The Authority of Law: Essays on Law and Morality. 2nd Edition. ed. Oxford: Clarendon Press, 2009.

RAZ, J. Legal Validity. In: The Authority of Law: Essays on Law and Morality. 2nd Edition. ed. Oxford: Clarendon Press, 2009.

RAZ, J. Legitimate Authority. In: The Authority of Law: Essays on Law and Morality. 2nd edition. ed. Oxford: Clarendon Press, 2009.

RAZ, J. On The Nature of Law. In: Between Authority and Interpretation. Oxford: Oxford University Press, 2009.

RAZ, J. The Argument from Justice, or How Not to Reply to Legal Positivism. In: The Authority of Law. 2nd Edition. ed. Oxford: Oxford University Press, 2009.

RAZ, J. The Claims of Law. In: The Authority of Law: Essays on Law and Morality. 2nd Edition. ed. Oxford: Clarendon Press, 2009.

RAZ, J. The Institutional Nature of Law. In: The Authority of Law: Essays on Law and Morality. 2nd Edition. ed. Oxford: Clarendon Press, 2009.

RAZ, J. The Obligation to Obey the Law. In: The Authority of Law: Essays on Law and Morality. 2nd Edition. ed. Oxford: Clarendon Press, 2009.

RAZ, J. The Problem of Authority: Revisiting the Service Conception. In: Between Authority and Interpretation: On the Theory of Law and Practical Reason. Oxford: Oxford University Press, 2009.

RAZ, J. The Rule of Law and its Virtue. In: The Authority of Law: Essays on Law and Morality. 2nd Edition. ed. Oxford: Clarendon Press, 2009.

RAZ, J. Two Views of the Nature of the Theory of Law: A Partial Comparison. In: RAZ, J. Between Authority and Interpretation - On the Theory of Law and Practical Reason. Oxford: Oxford University Press, 2009. 
REIS, L. S. Direito e Método: a contribuição de Ronald Dworkin. São Paulo: Dissertação de Mestrado - Departamento de Filosofia e Teoria Geral do Direito USP, 2013.

RIBEIRO, C. G. Desobediência Civil e Teorias do Direito. In: MACEDO JR., R. P. (org.). Teoria do Direito Contemporânea. Curitiba: Juruá Editora, 2017.

SAGER, L. G. Putting Law in Its Place. In: WALUCHOW, W. J. The Legacy of Ronald Dworkin. Oxford: Oxford University Press, 2016.

SIMMONDS, N. Law as a Moral Idea. Oxford: Oxford University Press, 2007.

SOPER, P. Choosing a Legal Theory on Moral Grounds. Social Philosophy \& Policy, v. 4, n. 1, 1986.

STRAVOPOULOS, N. Legal Interpretivism. Stanford Encyclopedia of Philosophy, 2014. Disponivel em: <https://plato.stanford.edu/entries/lawinterpretivist/ >. Acesso em: Setembro 2017.

STRAVOPOULOS, N. The Debate that Never Was. Harvard Law Review, v. 130, n. 2082, 2017.

SUNSTEIN, C.; VERMEULE, A. Interpretation and Institutions. Michigan Law Review, n. 885, 2003.

WALDRON, J. Jurisprudence for Hedgehogs. New York University Public Law and Legal Theory Working Papers, n. Paper 417, 2013.

WALUCHOW, W. J. Inclusive Legal Positivism. Oxford: Clarendon Press, 1994. 